LUCÉLIA DE ALMEIDA SILVA

\title{
O USO DO TEMPO NO COTIDIANO DE BEBÊS
}

\author{
Brasília - DF
}




\author{
UNIVERSIDADE DE BRASÍLIA \\ FACULDADE DE EDUCAÇÃO \\ PROGRAMA DE PÓS-GRADUAÇÃO EM EDUCAÇÃO
}

LUCÉLIA DE ALMEIDA SILVA

O USO DO TEMPO NO COTIDIANO DE BEBÊS

Dissertação de Mestrado apresentada ao Programa de Pós-Graduação em Educação da Faculdade de Educação da Universidade de Brasília como requisito para obtenção do grau de Mestre em Educação.

Linha de pesquisa: Escola, Aprendizagem, Ação Pedagógica e Subjetividade na Educação

Orientador: Profa. Dra. Fernanda Müller

Brasília - DF 
Ficha catalográfica elaborada automaticamente, com os dados fornecidos pelo(a) autor(a)

Silva, Lucélia de Almeida

o uso do tempo no cotidiano de bebês / Lucélia de Almeida Silva; orientador Fernanda Müller. -Brasilia, 2015. $107 \mathrm{p}$.

Dissertação (Mestrado - Mestrado em Educação) -Universidade de Brasilia, 2015.

1. Bebês. 2. Família. 3. Creche. 4. Diário do uso do tempo. 5. Cotidiano. I. Müller, Fernanda, orient. II. Título. 


\section{O USO DO TEMPO NO COTIDIANO DE BEBÊS}

Dissertação de Mestrado defendida junto à seguinte Banca Examinadora:

Brasília, 06 abril de 2015.

Profa. Dra. Fernanda Müller (Orientadora)

Faculdade de Educação - Universidade de Brasília

Profa. Dra. Angela Maria Scalabrin Coutinho (Examinadora externa)

Setor de Educação - Universidade Federal do Paraná

Profa. Dra. Maria Helena da Silva Carneiro (Examinadora interna)

Faculdade de Educação - Universidade de Brasília

Profa. Dra. Catia Piccolo Viero Devechi (Suplente)

Faculdade de Educação - Universidade de Brasília 


\section{Agradecimentos}

À Fernanda Müller que me orientou durante o desenvolvimento desse trabalho, pelo grande aprendizado e atenção constante.

Ao meu marido, Estevon, que me acompanhou durante todo esse período lendo, fazendo críticas ao trabalho, compreendendo meus momentos de ausência, por me amar e me cuidar, dando todo o suporte necessário.

Ao professor Sadi Dal Rosso pela ajuda na validação do instrumento de pesquisa, pelas indicações de leitura e contribuições ao trabalho durante a banca de qualificação.

Às professoras Angela Maria Scalabrin Coutinho e Maria Helena da Silva Carneiro que fizeram parte da minha banca de defesa e deram valiosas contribuições ao texto.

Às professoras Claudia Pato, Wivian Weller e Ingrid Dittrich Wiggers que durante as disciplinas me instigaram a pensar sobre a configuração do projeto bem como me apresentaram a um referencial teórico que contribuiu para minha pesquisa.

Às amigas da Coordenação de Educação Infantil que me incentivaram a fazer o mestrado, pela torcida nas minhas conquistas, por sempre me apoiarem e me tranquilizarem durante esta trajetória.

Às amigas do GIPI pelas trocas, conversas e apoio.

Aos amigos que me incentivaram, me tranquilizaram e estiveram dispostos a conversar sobre o meu trabalho, especialmente a Lulis pelo carinho de sempre.

À Rhaisa, amiga inseparável durante este percurso, por compartilhar a trajetória do mestrado, pelas leituras, pela ajuda nos momentos de dúvidas, por me fazer acreditar que eu era capaz de participar de um congresso internacional, pelas sessões de caminhada e malhação que aliviaram nossas tensões, pelos risos, olhares, palavras e compartilhamento de situações que fomos construindo.

Ao meu irmão Aristóteles pela leitura e as críticas ao texto. ausência.

À minha família que sempre me apoiou, incentivou e compreendeu meus momentos de

Aos colegas e amigos da UnB, pelas leituras, discussões e conselhos.

Aos bebês Augusto e Clarice por terem compartilhado comigo uma parte de suas vidas, ensinando-me a ver e ouvir com respeito e sensibilidade.

Às mães Isabel e Carolina por compartilharem comigo o cotidiano de suas famílias e pela ajuda, sem elas a realização desse estudo não teria sido possível.

À todos os profissionais da creche investigada pela confiança e abertura para realização da pesquisa. 
Ao PPGE-UnB e a FINATEC pelos financiamentos para participação nos eventos que foram importantes momentos de troca com os pares.

À SEDF pela licença remunerada concedida.

À todos que me ajudaram neste mestrado, saibam que parte deste trabalho foi graças a vocês, tão especiais, muito obrigada! 


\title{
OraÇÃo AO TEMPO
}

\author{
Caetano Veloso
}

És um senhor tão bonito Quanto a cara do meu filho Tempo tempo tempo tempo Vou te fazer um pedido Tempo tempo tempo tempo

Compositor de destinos Tambor de todos os ritmos Tempo tempo tempo tempo Entro num acordo contigo Tempo tempo tempo tempo

Por seres tão inventivo

E pareceres contínuo

Tempo tempo tempo tempo És um dos deuses mais lindo Tempo tempo tempo tempo

Que sejas ainda mais vivo No som do meu estribilho Tempo tempo tempo tempo Ouve bem o que te digo Tempo tempo tempo tempo 
No campo dos Estudos da Infância tem crescido o número de pesquisas que destacam as potencialidades das ações dos bebês e não suas carências. Contribuindo para este movimento, o objetivo desta pesquisa foi compreender o uso do tempo no cotidiano de dois bebês, um menino e uma menina, de 11 e 18 meses respectivamente. Ambos os bebês frequentavam uma creche pública do Distrito Federal. Para a coleta dos dados foram utilizados o Diário de Uso do Tempo para o registro das atividades dos bebês as quais ocorreram em um período 24 horas do dia da semana e 24 horas do final de semana. Realizaram-se também entrevistas subsequentes com as mães dos bebês. Na análise recorreu-se aos conceitos de Erving Goffman os quais permitiram compreender as atividades cotidianas dos bebês. Identificou-se que grande parte das atividades dos bebês ocorria a partir de interações. Goffmam contribuiu para compreensão de que os encontros dos bebês se configuravam em situações sociais. As categorias analíticas destacadas neste trabalho foram: sono, alimentação, higiene e brincadeiras. Para cada situação vivenciada pelos bebês, houve um ethos caracterizador que permitia reconhecer qual o comportamento esperado por eles. Contudo, os bebês não se limitaram a responder apenas a isso, pois houve uma negociação entre as suas demandas e as determinações impostas pelos contextos. As ações dos bebês mostraram-se parte importante da organização do tempo familiar, em alguns casos com mais ou menos centralidade. Na creche houve uma estruturação mais rígida do tempo e do espaço. Por fim, considera-se que a inclusão dos bebês nesses tipos de estudos sobre o Uso do Tempo poderia facilitar os estudos comparativos acerca do cotidiano de bebês em diferentes contextos socioculturais.

Palavras-chave: Bebês. Família. Creche. Diário do uso do tempo. Cotidiano. 


\begin{abstract}
In the field of Childhood Studies, there has been an increase in the number of publications highlighting the potential of babies' actions rather than their needs. The objective of the present study was to understand the daily time-use of two babies; one boy and one girl aged 11 and 18 months respectively. Both babies attended a public early childhood education center in Distrito Federal in Brazil. The Time-Use Diary was employed to collect data - registering the babies' activities over 24 hours on one week day and again for one weekend day. Subsequent interviews were held with both mothers. Erving Goffman's concepts were used as a reference in order to understand the babies' daily activities. The study found that the majority of activities came from interactions. Goffman's concept corroborated the understanding that the babies' interactions configured social situations. The analytical categories highlighted were sleep, feeding, hygiene and play. For each situation there was an ethos characterizer which allowed the babies to recognize what was expected. However, the babies did not only respond with what was expected of them but by negotiating their needs against the impositions of the situation. The babies' actions were demonstrably important in family time organization - in some cases with either more or less centrality. However, in the early childhood education center there was a more rigid structure of time and space. In conclusion, including babies in these time-use study types might help comparative studies concerning the babies day-to-day in different sociocultural contexts.
\end{abstract}

Keywords: Babies. Family. Early childhood education center. Time-use diary. Day-to-day. 


\section{LISTA DE GRÁFICOS}

Gráfico 1 - Porcentagem de crianças de 0 a 3 anos na Educação Infantil 33

Gráfico 2 - Porcentagem de crianças de 4 e 5 anos na Educação Infantil 


\section{LISTA DE QUADROS}

Quadro 1 - Apresentação dos participantes

Quadro 2 - Data e local do preenchimento do Diário do Uso do Tempo

Quadro 3 - Dados gerados nos Diários de Augusto 46

Quadro 4 - Dados gerados nos Diários de Clarice. 47

Quadro 5 - Exemplo de categorias do Diário do Uso do Tempo de Augusto 52

Quadro 6 - Total de horas do dia da semana por subcategoria 61

Quadro 7 - Total de horas do final de semana por subcategoria 61

Quadro 8 - Interferência no sono de Augusto. 62

Quadro 9 - Outras atividades enquanto o bebê dormia

Quadro 10 - Negociação no momento do sono de Clarice .64

Quadro 11 - Negociação no momento da alimentação de Clarice 68

Quadro 12 - Augusto café da manhã 71

Quadro13 - Clarice almoço e café da tarde 72

Quadro 14 - Higiene Clarice. .72

Quadro 15 - Brincadeira - Uso do tempo total 77

Quadro 16 - Exemplo de registro da brincadeira no Diário de Clarice 80

Quadro 17 - Exemplo esquema primário de brincadeira 84

Quadro 18 -Tonalização - brincadeira entre pares 87

Quadro 19 - Tonalização - Brincadeira entre bebês e adultos 88 


\section{Lista de Abreviaturas e Siglas}

CEINF - Coordenação de Educação Infantil

CEP/IH - Comitê de Ética em Pesquisa de Ciências Humanas

DF - Distrito Federal

GIPI - Grupo Interdisciplinar de Pesquisa sobre a Infância

HETUS - Harmonised European Time Use Surveys

IBGE - Instituto Brasileiro de Geografia e Estatística

INEP - Instituto Nacional de Estudos e Pesquisa Educacionais Anísio Teixeira

LDB - Lei de Diretrizes e Bases

MEC - Ministério da Educação

PNAD - Pesquisa Nacional por Amostra de Domicílios

PNE - Plano Nacional de Educação

RedSig - Rede de Significações

SEDEST - Secretaria de Estado de Desenvolvimento Social e Transferência de Renda

SEDF - Secretaria de Estado de Educação do Distrito Federal

UnB - Universidade de Brasília

Unicamp - Universidade Estadual de Campinas 


\section{Sumário}

INTRODUÇÃO .................................................................................................................................................13

2 TEMPO, TEMPO, TEMPO, TEMPO - REFERENCIAL CONCEITUAL .................................................26

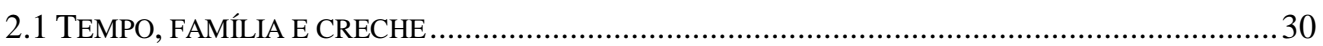

3 TEMPO, ENTRO NUM ACORdO CONTIGO - PERCURSOS DA PESQUISA .............................................38

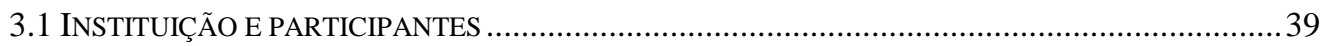

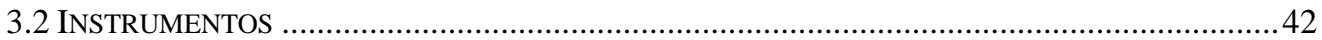

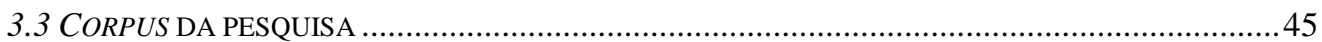

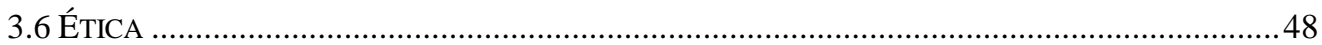

4 TEMPO, OUVE BEM O QUE TE DIGO - ANÁLISE ...........................................................................51

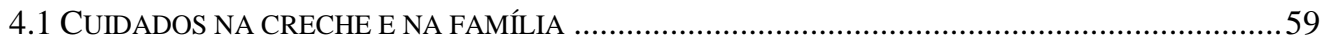

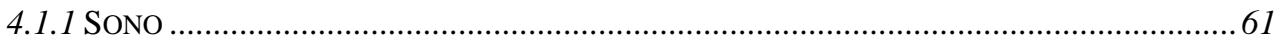

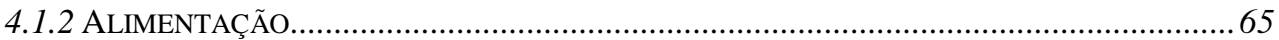

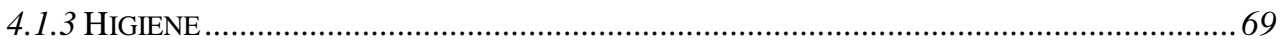

4.1.4 CONTRASTANDO AS SITUAÇÕES SOCIAIS RELACIONADAS AOS CUIDADOS .......................70

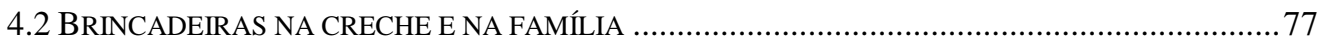

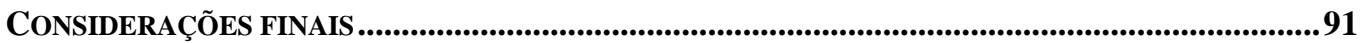

REFERÊNCIAS ..........................................................................................................................................96

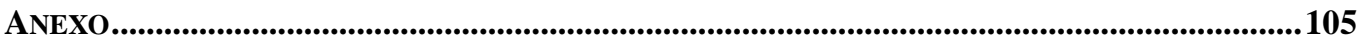

ANEXo A - PARECER DE APROVAÇÃo Do COMITÊ DE ÉTICA EM PESQUISA ...............................105 


\section{INTRODUÇÃO}

O tempo não existe em si.

(Nobert Elias, 1998)

Nobert Elias afirma que o tempo não é um dado objetivo, nem uma estrutura $a$ priori do espírito, mas um símbolo social fruto de um longo processo de aprendizagem. Instigadas por esta afirmativa é que nos propomos a estudar o tempo dos bebês. Se o conceito de tempo muitas vezes sofre certa naturalização, isso também é evidente em relação às concepções de bebê. Por muito tempo os bebês foram considerados apenas como dependentes de seus instintos biológicos, sendo assim, suas mães eram vistas como as melhores cuidadoras, uma vez que a elas é atribuído o instinto maternal.

Contudo, um novo paradigma da infância vem sendo estabelecido e, portanto, uma nova visão sobre os bebês. O novo paradigma nos estudos da infância propõe a incorporação de crianças nas pesquisas conduzidas sobre elas, como também estudar a infância como categoria social. James e Prout (1999, p. 8) elencam 6 pontos como principais características desse novo paradigma em relação à infância, quais sejam: 1) é uma construção social; 2) é uma variável da análise social, não sendo possível separá-la de outras categorias como: classe social, gênero e etnia; 3) as relações sociais e culturais das crianças são valiosas em seu sentido próprio, independente da perspectiva e interesse dos adultos; 4) as crianças são e devem ser vistas como ativas na construção de suas próprias vidas sociais; 5) a etnografia é um método útil para os estudos da infância, uma vez que permite a participação das crianças mais diretamente; 6) proclamar um novo paradigma no estudo sociológico da infância é se engajar num processo de "reconstrução" da criança e da sociedade.

Pensando em contribuir para os estudos da infância, mais precisamente para o campo dos estudos com/sobre bebês, este trabalho foi desenvolvido. Partindo da dimensão temporal, investigamos o uso do tempo no cotidiano de dois bebês, tanto na família, como na creche. Pois, como afirmam Ben-Arieh e Ofir (2002), conhecer melhor as atividades diárias das crianças nos permite uma compreensão mais ampla de suas vidas, bem como pode revelar o padrão de infância em uma determinada sociedade. Nas palavras dos autores: 
Para ter um melhor conhecimento e compreensão das vidas das crianças e de seu bem-estar, especialmente a partir de uma perspectiva centrada na criança, devemos conhecer profundamente suas atividades diárias e seu uso do tempo. Um exame das atividades das crianças e seu uso do tempo irão destacar sua participação na sociedade, como indivíduos e como um grupo. Essas informações irão revelar o padrão da infância em uma determinada sociedade (BEN-ARIEH; OFIR, 2002, p. 225, tradução nossa).

Antes de prosseguir com a discussão, sentimos a necessidade de situar de onde falamos, pois foi a partir das indagações entre a formação acadêmica e a prática profissional que as ideias desta dissertação foram fomentadas. Graduei-me em Pedagogia na Universidade Estadual de Campinas - Unicamp, em 2006. Minha primeira experiência docente ocorreu com uma turma de Educação Infantil, com crianças de 3 anos. A transição do mundo acadêmico para o mundo do trabalho não foi fácil, fazendo com que comparasse, a todo momento, minhas bases teóricas com a prática exercida. Diante da demanda constante de ações e decisões rápidas, me via em muitos momentos reproduzindo práticas que já eram conhecidas e transmitidas na instituição, mas que minha formação informava que não eram as melhores. Nesse momento, não sabia como relacionar meu repertório teórico com a nova realidade encontrada.

Segundo Campos (1999), até hoje não sabemos equacionar a relação entre teoria e prática, principalmente no que diz respeito ao lugar e ao modo que a formação prática deve ocupar nos currículos, e que o "[...] problema se acentua no caso do professor iniciante, para o qual não se prevê, no Brasil, nenhum tipo de transição até que adquira autonomia no seu trabalho" (CAMPOS, 1999, p.136).

Essa situação me levou ao meu primeiro movimento investigativo, tentando encontrar um caminho entre o currículo aprendido na universidade e o currículo da Educação Infantil. Para superação desse momento, foram importantes as discussões com outros colegas que se encontravam na mesma situação, bem como participar de um grupo de pesquisa na universidade, que reunia professores da rede metropolitana de Campinas. Depois dessa experiência, vieram outras com crianças de outras idades, do Ensino Fundamental e Educação Infantil, em diferentes redes de Ensino.

Minha última e atual experiência como membro da equipe da Coordenação de Educação Infantil (CEINF) da Secretaria de Estado de Educação do Distrito Federal (SEDF) me levou ao meu segundo movimento investigativo e à produção dessa dissertação. Foi no monitoramento das instituições de Educação Infantil da rede, bem 
como nas discussões com os profissionais da SEDF acerca das práticas e do conteúdo do Currículo da Educação Infantil, principalmente no que concerne aos bebês, que fui confrontada novamente entre a prática estabelecida nas instituições e a teoria discutida pelos novos estudos sobre/com bebês.

Nas discussões com os pares, era recorrente perceber em seus discursos as referências à Psicologia do Desenvolvimento, uma vez que essa área possui tradição nos estudos de bebês e tem uma ampla divulgação, a exemplo dos periódicos especializados que destacam os estudos com/sobre bebês ${ }^{1}$, bem como os manuais de puericultura.

Um dos manuais mais populares é o The Common Sense Book of Baby and Child Care, do pediatra Benjamin McLane Spock, que teve sua primeira publicação em julho de 1946. No Brasil, o manual mais conhecido é "A Vida do Bebê", de 1941, do pediatra Rinaldo de Lamare. Esses manuais ainda são muito conhecidos e comercializados. Portanto, as referências das colegas ao estímulo ao desenvolvimento dos bebês em contextos individualizados eram compreensíveis.

No caso dos manuais de puericultura foi a generalização de uma concepção sobre o desenvolvimento dos bebês que acabou por transformar a diversidade em padronização. Como afirmam Barbosa e Fochi (2012, p. 1):

Encontramos na tradição científica dos estudos de bebês e crianças pequenas, pesquisas de cunho psicológico, geralmente, com atenção aos bebês em ambientes recriados ou artificiais, nos estudos da díade mãe-bebê com base em métodos experimentais - oriundos da saúde, antropologia e psicologia - o que evidencia a incipiência de experiências de pesquisas com os bebês em espaços coletivos reais.

Apesar dessa visão predominante sobre os bebês, o cenário acadêmico tem apresentado mudanças, percebidas inclusive no campo da Psicologia do Desenvolvimento. Inicialmente a disciplina que tratava principalmente da infância e da adolescência, passou a abordar o desenvolvimento ao longo do ciclo de vida. Assim, acabou estabelecendo conexões com outras áreas da Psicologia, como a Psicologia Social, Educacional, Cognitiva e a considerar os diversos fatores que afetam o desenvolvimento

\footnotetext{
${ }^{1}$ A exemplo do Infancy, Infant Behavior and Development, Advances on Infancy Research, além de periódicos especializados em desenvolvimento infantil incluírem artigos sobre bebês (GOTTLIEB, 2012).
} 
humano ao longo da vida. Segundo Mota (2005, p. 107), pode-se definir a Psicologia do Desenvolvimento na atualidade como o:

[...] estudo, através de metodologia específica e levando em consideração o contexto sócio-histórico, das múltiplas variáveis, sejam elas cognitivas, afetivas, biológicas ou sociais, internas ou externas ao indivíduo que afetam o desenvolvimento humano ao longo da vida.

Os estudos psicológicos clássicos sobre os bebês inicialmente se preocuparam em encontrar padrões/etapas do desenvolvimento, muitas vezes considerando contextos isolados e individuais. Contudo, trabalhos mais recentes passaram a também considerar outros fatores. De acordo com Carvalho e Pedrosa (2002, p. 182),

[...] pode-se considerar praticamente consensuais na atual cultura da Psicologia do Desenvolvimento as noções a respeito da criança como agente ativo de seu desenvolvimento e do lugar da interação social e da interação criança-criança nesse processo (CAMAIONI, 1980; CARVALHO, 1992; PEDROSA, 1989; STAMBAK \& VERBA, 1986; VERBA, 1994), ainda que nem sempre esses pressupostos conduzam às mesmas perguntas, níveis de análise e interpretações.

Percebemos, nas últimas décadas, uma preocupação de diversos pesquisadores da infância para que os estudos com/sobre bebês ganhem destaque. Alguns teóricos fazem convocações e provocações para que pesquisadores das diversas áreas passem a dar mais atenção a esse tema. Gottlieb (2012) propõe que a Antropologia leve a sério os bebês e afirma que antropólogos “[...] prestaram pouca atenção nas crianças pequenas [...]. Além disso, quanto menor a criança menos atenção é prestada" (GOTTLIEB, 2012, p. 84).

No cenário brasileiro, Silva et al. (2010) mostram, a partir de um mapeamento dos grupos e instituições que produzem pesquisas na área de educação da infância, criança e Educação Infantil, que esses temas mobilizam poucos grupos externos às áreas de Educação e Psicologia. Furtado (2014) e Silva (2014), em seus levantamentos bibliográficos, constataram que ainda são poucas as pesquisas na área educacional, no Brasil, com bebês, apesar do crescente número de pesquisas sobre a infância.

Todavia, ainda que o tema não tenha obtido um apelo significativo, alguns resultados são importantes para seguirmos estudos sobre os bebês em ambientes coletivos, dentre os quais: a capacidade interativa dos bebês no primeiro ano de vida (FRANCHI e VASCONCELOS et al., 2003); as ações dos bebês que influenciam o comportamento de outros bebês (ANJOS et al., 2004); o papel da linguagem na 
construção de significados entre bebês (CAMERA, 2006); as múltiplas relações estabelecidas pelos bebês no espaço da creche (SCHMITT, 2008); as ações sociais dos bebês que modificam a sua própria ação (COUTINHO, 2010); a necessidade de planejamento dos espaços da creche para propiciar interações de bebês (GOBBATO, 2011); as relações entre adultos e bebês no espaço da creche (GUIMARÃES, 2011).

O presente estudo foi desenvolvido a partir do levantamento de pesquisas do campo da Educação e também de áreas correlatas, tendo como objetivo oferecer resultados sobre modos de vida de bebês em contraste com as instituições sociais, dentre elas, a família e a creche. O estudo também visa contribuir para o repertório de pesquisas com/sobre bebês que reconhecem as potencialidades de suas ações. Buscamos observar as atividades no contexto em que são vividas e questionar a existência de um único padrão de desenvolvimento. Assim, a pergunta formulada para este estudo centra-se em: Como bebês usam o tempo em seu cotidiano?

Dessa forma, o objetivo geral desta pesquisa foi analisar o uso do tempo a partir da descrição do cotidiano ${ }^{2}$ de dois bebês que frequentavam uma creche pública do Distrito Federal. E como objetivo específico identificar e analisar categorias a partir do uso do tempo de bebês na creche e no contexto familiar em um período de 24 horas do dia da semana e 24 horas do final de semana.

Vale destacar aqui o que entendemos pela categoria bebê, pois os estudos da infância não apresentam um consenso na definição desse termo; nem mesmo as experiências dos diferentes contextos culturais são universais. Por exemplo: para algumas linhas de pesquisa da Psicologia do Desenvolvimento, o bebê pode ser definido em função de sua capacidade locomotora, ou seja, ao adquirir independência para andar passam para outro estágio, o que "normalmente" ocorre por volta dos dois anos de idade. Para o povo Lahu do Sudoeste da China, está ligado à capacidade de andar com confiança e falar com

\footnotetext{
${ }^{2}$ Vale destacar que cotidiano se diferencia de rotina. A palavra cotidiano tem origem latina, quot dies e significa, ao mesmo tempo, um dia e todos os dias. Como afirma Guarinello (2004, p. 25), tem "[...] dois sentidos temporais complementares, [...] o que acontece em um dado dia, num tempo brevíssimo, uma efeméride, e o que acontece todos os dias, [...] num tempo potencialmente longo". Já a palavra rotina tem origem francesa, um derivado da palavra rupta (rota), que significa caminho utilizado normalmente; itinerário habitual.
} 
algum grau de expressão verbal. Há ainda definições relacionadas a rituais de passagem e à idade cronológica (GOTTLIEB, 2012).

James e James (2008) discutem que, embora nas sociedades ocidentais contemporâneas a idade seja comumente considerada um aspecto fundamental da identidade de uma pessoa e calculada com base na passagem dos anos, essa conta da passagem do tempo não é universal. Ainda afirmam que a idade tem sido usada para estabelecer limites e marcas para separar crianças de adultos. Os autores elencam alguns problemas ao se associar idade à criança. Um deles refere-se ao sistema escolar, que relaciona idade a um currículo; crianças de uma determinada idade são responsáveis por aprender determinados conteúdos e, se não o fazem, ou o fazem com certa rapidez são consideradas atrasadas ou precoces. Outro problema está relacionado às restrições, proteções ou permissões para as atividades das crianças.

Contudo, foi necessário partir de um marco para definir o bebê. Optamos pela categoria idade, seguindo uma definição socialmente construída e legitimada em documentos oficiais, ou seja, aquela definida pela rede de ensino no qual desenvolvemos a pesquisa. A SEDF, inspirada nas definições do Ministério da Educação (MEC) ${ }^{3}$, considera bebê as crianças de 0 a 2 anos de idade. Em nosso estudo, mais importante do que ter definido a categoria bebê, nos era crucial realizar a pesquisa com crianças pequenas com a menor idade possível, considerando que há uma maior lacuna de pesquisas em relação a essa faixa etária.

O interesse em estudar o cotidiano se deve à busca em destacar as ações dos bebês, que parecem ser banais e, até certo ponto, encaradas como naturais. Dessa forma, o estudo possibilitaria explorar as ações da vida cotidiana com lentes teóricas, pois essas ações geralmente são entendidas por meio de descrições do senso comum. Como afirma Geertz (2003), as afirmações do senso comum são construções culturais e convincentemente estruturadas para parecer transparentes e óbvias. Ou seja, buscamos olhar para o cotidiano

\footnotetext{
${ }^{3}$ O documento "Práticas Cotidianas na Educação Infantil - Bases para a Reflexão sobre as Orientações Curriculares" (MEC, 2009), voltado para a educação de crianças de 0 a 6 anos, compreende bebês como crianças de 0 a 18 meses e crianças bem pequenas, como crianças entre 19 meses e 3 anos e 11 meses.
} 
procurando compreender as configurações atuais da infância, mais especificamente da vida dos bebês.

De acordo com Barbosa (2006) os estudos sobre o cotidiano ganharam importância após o século XVIII, quando a literatura e a arte passaram a retratar a riqueza da vida cotidiana em seus romances e pinturas. Diversas áreas passaram a se debruçar sobre o cotidiano, seja ao considerá-lo objeto de estudo, seja como estratégia metodológica. Dessa forma, o cotidiano deixa de ser percebido como repetição e mera expressão do senso-comum e passa a ser visto como espaço-tempo " [...] da complexidade da vida social, na qual se inscreve toda produção de conhecimento e práticas científicas, sociais, grupais, individuais" (OLIVEIRA, 2008, p. 163). De forma geral, os estudos do cotidiano possibilitam a análise do indivíduo frente as atividades do dia a dia, envolvido em relações com outros indivíduos (GIL; GIL FILHO, 2008).

Importantes autores dedicaram suas obras ao estudo do cotidiano, tais como: Erving Goffmann, Alfred Schutz, Henri Lefebvre, Michel de Certeau, Agnes Heller. A obra desses autores representa um importante marco para as discussões em relação a esta temática. Goffman destaca o cotidiano como espaço de interações sociais, no qual os indivíduos representam papéis. Schutz entende o cotidiano como mundo de vida, perceptível apenas na perspectiva de cada indivíduo. Lefebvre considera o cotidiano um produto do capitalismo. Certeau afirma que o cotidiano se constitui de rupturas, e não apenas de regularidades normativamente esperadas. Já Heller considera o cotidiano como o mundo das objetivações, onde há espaço para as reproduções bem como para as ações criativas, inovadoras (PATTO, 1993; GUARINELLO, 2004; LEITE, 2010).

Os estudos do uso do tempo permitem explorar o que os indivíduos fazem em seu cotidiano e um crescente corpo de pesquisas internacionais tem destacado a sua importância ${ }^{4}$. Minkoff e Riley (2011) afirmam que, a partir desse tipo de estudo, é possível compreender a cotidianidade, o que os indivíduos fazem com o seu tempo e o porquê, bem como investigar seu uso e a experiência subjetiva dos acontecimentos. Segundo Craig (2014, p. 471, tradução nossa) esse tipo de estudo é “[...] uma janela para

\footnotetext{
${ }^{4}$ De acordo com Robinson (1988 apud TEIXEIRA; CRUZ, 2006b, p. 769), esse tipo de pesquisa pode ser classificado como uma abordagem "micro-comportamental", onde os participantes fornecem informações sobre as atividades concretas realizadas em dias específicos.
} 
a vida diária que mostra todas as coisas que as pessoas realmente fazem”. Igualmente, segundo a autora, “[...] compreender a forma como as pessoas gastam o tempo é essencial para a compreensão de como suas vidas são vividas" (CRAIG, 2014, p. 471, tradução nossa).

Diversos estudos vêm sendo conduzidos com a utilização de grandes amostragens nacionais e internacionais que permitem análises comparativas entre países sobre as configurações atuais do tempo no dia a dia dos indivíduos. Em geral, tais estudos são realizados com a população adulta dando destaque para temas como trabalho remunerado ou não, tempo gasto com cuidados com crianças e idosos, como também diferenças de gênero. Todavia, o Brasil ainda não tem tradição em pesquisas de grande porte sobre o uso do tempo. De acordo com Aguiar (2010, p. 64), “[...] a experiência brasileira com diários tem um caráter localizado e as perguntas sobre uso do tempo, apresentadas em um contexto nacional, referem-se a um número restrito de atividades".

Estudos de revisão da literatura internacional (LARSON; VERMA, 1999; BENARIEH; OFIR, 2002; VOGLER; MORROW; WOODHEAD, 2009; CRAIG, 2014) mostram uma lacuna de investigação sobre o uso do tempo das crianças, principalmente de bebês. Essa constatação motivou o desenvolvimento da presente pesquisa. De acordo com Craig (2014), a utilização desse tipo de estudo com crianças “[...] pode oferecer uma medida objetiva do que as crianças fazem, onde fazem e com quem" (CRAIG, 2014, p. 47, tradução nossa), o que permitiria uma melhor compreensão do universo que envolve os bebês.

Ainda que as pesquisas sobre o uso do tempo com crianças sejam incipientes, a temática "tempo e infância” não é nova. De acordo com Ben-Arieh e Ofir (2002), Vogler, Morrow e Woodhead (2009), a temática "tempo e infância" possui centralidade nas pesquisas desenvolvidas pelas diversas disciplinas que compõem os estudos da infância, pois uma característica inevitável do desenvolvimento infantil é que as crianças mudam com o tempo.

Baseados nos textos de Larson e Verma (1999); Ben-Arieh e Ofir (2002); Vogler, Morrow e Woodhead (2009) e Craig (2014) e nossa revisão de literatura sobre o uso do tempo das crianças, destacamos, a seguir, as principais configurações e entendimento sobre o uso do tempo das crianças. 
Pesquisas têm destacado a preocupação da sociedade em controlar o tempo das crianças (CUNNINGHAM, 1991; CUNNINGHAM E VIAZZO, 1996; WAGNER, 1982; ZELIZER, 1985). A preocupação com o tempo das crianças se alterou historicamente, configurando-se de forma diferenciada nos diversos contextos socioculturais. A exemplo do que Cunningham (1991) trata em seu estudo, a preocupação com o tempo das crianças na Grã-Bretanha nos séculos XVII e XVIII era de evitar a vadiagem das crianças pobres. De acordo com esse autor, as escolas existiam, mas serviam, para preparar as crianças para o futuro ao qual já estavam predestinadas. Dessa forma, as crianças desocupadas ou inativas (de rua) eram vistas como uma ameça à sociedade, pois viviam ociosas, o que, na visão da época, aumentaria a propensão ao crime, com a capacidade de minar a autoridade do estado.

A maioria das pesquisas de âmbito internacional sobre os padrões de atividades cotidianas de crianças aborda aspectos da escolarização. Além de Cunningham (1991), Wagner (1982, p. 3) afirma que a aprendizagem e a escolaridade foram utilizadas como meio de "recuperar" as crianças. Assim, as escolas passaram a ter um papel importante na gestão do tempo das crianças, definindo comportamentos a partir dos ritmos estabelecidos pela pontualidade e regularidade. No entanto, os autores argumentam que as crianças continuaram a trabalhar antes e depois da escola.

Cunningham (1991) e Zelizer (1985) afirmam que o pano de fundo para o deslocamento do estereótipo de criança dentro da sociedade estava na mudança da percepção do papel da criança dentro da família, o qual se desloca de um papel econômico para um papel emocional. De acordo com os autores, foi só no início do século XX que essa ideia tornou-se amplamente aceita. Em suma: antes da industrialização/urbanização da Inglaterra, as crianças pobres trabalhavam para evitar a ociosidade e a delinquência, bem como contribuíam economicamente, mas com a mudança de valores, o projeto de sociedade previa a manutenção das crianças na escola e fora do trabalho.

Nesse sentido, de acordo com Vogler, Morrow e Woodhead (2009), no final do século XIX, preocupações sobre o bem-estar das crianças pobres na Inglaterra centraramse no uso do tempo das crianças fora da escola. Pecora, Murray e Wartella (2006) afirmam que, em meados do século XX, a preocupação girava em torno do uso ou do mau uso do tempo de lazer infantil, fazendo parte das perguntas de pesquisa dessa época o tempo gasto por crianças assistindo à televisão e jogando e acessando Internet. Mulvihill, Rivers 
e Aggelton (2000) destacam preocupações mais recentes com o tempo gasto em atividades físicas e Yeung et. al. (2001) abordam a quantidade de tempo gasto pelas crianças com os pais após a separação destes.

Vogler, Morrow e Woodhead (2009) destacam que pesquisas realizadas nas últimas décadas sobre o uso do tempo das crianças têm sido conduzidas por economistas que, geralmente, coletam os dados com adultos por meio de pesquisas domiciliares, e não com as crianças. Os autores destacam a pesquisa realizada pelo economista Rodgers, que produziu uma tipologia das atividades infantis baseada na Organização Internacional do Trabalho, a qual utiliza categorias ligadas essencialmente ao trabalho como: trabalho doméstico e não doméstico, pago e não pago, além de escolaridade, recreação e lazer e atividades reprodutivas (cuidados pessoais, comer e dormir) que passou a influenciar os trabalhos sobre o uso do tempo das crianças.

Estudos etnográficos também foram desenvolvidos na busca de compreensão do valor econômico das atividades das crianças. Segundo Vogler, Morrow e Woodhead (2009), as pesquisas de Reynolds (1991) e Nieuwenhuys (1994) tornaram-se referência para os estudos nessa área.

Reynolds (1991) realizou uma pesquisa sobre a diferença de gênero no trabalho infantil das crianças do Zimbabué. O autor discute que o valor do trabalho de meninos e de meninas está quase em igualdade com o dos adultos e destaca que as crianças utilizam o trabalho como forma de liberdade pessoal, uma vez que o tempo e as regras sociais restringem a sua autonomia. Ao se recusarem a trabalhar, as crianças rejeitam uma atividade que é culturalmente muito valorizada.

Nieuwenhuys (1994) realizou um estudo etnográfico em uma aldeia em Kerala sobre as atividades diárias das crianças. $\mathrm{O}$ pesquisador argumenta que, entre as crianças pobres, o sexo e idade são definidores da divisão do trabalho.

Pesquisas mais recentes, como a de Punch (2000), destacam outros aspetos relevantes para a compreenssão do tempo das crianças, que teria o seu valor intrinsecamente ligado ao contexto sócio-cultural. Vogler, Morrow e Woodhead (2009) 
afirmam que pesquisas como a de Punch $^{5}$ não se preocupam apenas com o aspecto econômico do trabalho realizado pelas crianças, mas também com os meios pelos quais as atividades são realizadas. Segundo os autores, “[...] analisando o uso do tempo das crianças pode se extrair informações sobre as atividades valorizadas dentro de uma determinada comunidade, bem como sobre as relações de poder subjacentes a esses valores.” (VOGLER; MORROW; WOODHEAD, 2009, p. 7, tradução nossa).

Vogler, Morrow e Woodhead (2009) concluem que a preocupação com o tempo das crianças não é recente, porém, apenas com as mudanças teóricas nos estudos sobre a infância é que as crianças passaram a ser sujeitos desse tipo de pesquisa. Ainda assim, as discussões sobre o uso do tempo das crianças estão relacionadas ao trabalho e como essas atividades podem entrar em conflito com a educação.

Dentro desse escopo de pesquisas influenciadas pelas mudanças teóricas, destacamos três estudos recentes, quais sejam: Teixeira e Cruz (2006a), Christensen e James (2008) e Minkoff e Riley (2011), os quais buscaram uma lógica diferente no que diz respeito aos estudos sobre o uso do tempo, ao tentarem compreender o cotidiano das crianças a partir do ponto de vista delas próprias. Para tanto, essas pesquisas construíram metodologias capazes de considerar as especificidades da infância.

Teixeira e Cruz (2006a) conduziram uma análise comparativa em duas bases de dados sobre as atividades das crianças portuguesas de 8 a 10 anos, entre os anos de 1999 a 2006, tanto em dias de semana como de final de semana, tentando captar as mudanças no uso do tempo das crianças. Demonstram que, em 2006, as crianças:

[...] passam significativamente menos tempo, em atividades relacionadas com a escola, e em atividades de convívio e de socialização, do que as crianças de 1999. Por outro lado, passam mais tempo a realizar exercício físico e em atividades de jogo (principalmente jogos electrónicos). Todavia, as crianças de 2006 passam menos tempo a dormir nos dias de semana, e mais tempo a dormir ao fim-de-semana do que as crianças de 1999. (TEIXEIRA; CRUZ, 2006a, $\mathrm{s} / \mathrm{n})$.

\footnotetext{
5 Punch (2000) explorou quatro aspectos do cotidiano das crianças na Bolívia rural, quais sejam: trabalho, escola, casa e jogo. Entre seus achados está que a determinação do tempo das crianças depende, em grande parte, de seu grau de dependência dos adultos em relação ao trabalho realizado. O estudo também revelou que, dentro desse conjunto de responsabilidades e obrigações, as crianças conseguem barganhar e negociar o seu uso do tempo e do espaço por meio de uma variedade de estratégias. Por exemplo, muitas vezes, usam recados e outras tarefas como oportunidades para se encontrar com amigos.
} 
Nesse estudo, a escola aparece como organizadora social das rotinas das crianças, fazendo com que os tempos entre elas sejam homogêneos, deixando pouco espaço para que haja diferenças nas atividades em que as crianças se envolvem.

Já os estudos de Christensen e James (2008) foram realizados com crianças de 10 anos de idade que viviam em zonas urbanas e rurais da Inglaterra. A pesquisa tomou como foco diversos aspectos do uso do tempo de crianças em suas vidas cotidianas em casa e na escola. As crianças se mostraram competentes para representar as suas próprias experiências diárias individuais e sociais.

Minkoff e Riley (2011) investigaram se crianças de 6 e 7 anos, do norte de Israel, eram capazes de compreender o tempo em termos de ritmo e temporalidade. Os resultados mostraram que, apesar da dificuldade em compreender a hora do relógio e tempo de calendário, as crianças foram capazes de descrever suas rotinas diárias por meio de desenhos.

Além dos estudos apresentados acima, destacamos também os de Bondioli (2004), Galdabino (2004), Nigito (2004), Gariboldi (2004), Ferrari (2004), Becchi e Borando (2004) e Zeiher (2004). Trata-se das pesquisas condensadas no livro "O tempo no cotidiano infantil: perspectivas de pesquisa e estudo de casos" em que os estudos buscaram evidenciar as "[...] qualidades das sequências temporais dos eventos do dia-adia das crianças" (FAEDI, 2004, p. 12). A maior parte desses estudos foram desenvolvidos no contexto da creche. Os pesquisadores descreveram o cotidiano das crianças na instituição de Educação Infantil por meio de um Diário e buscaram fazer a leitura dos dados sob diferentes aspectos, tais como analisando a gestão do tempo e o fluxo de atividades.

Nossa pesquisa guarda uma certa semelhança com a de Bondioli (2004). A autora realizou um estudo de caso da dinâmica da vida cotidiana de uma criança de 3 anos de idade, em casa e na escola. Nele, a pesquisadora discutiu o envolvimento, a adesão e a participação da criança no cotidiano da escola e da casa. Em nosso caso, a discussão também pautou-se no âmbito da casa e da creche diferenciando-se no recorte apresentado na análise dos dados que centrou-se nas situações sociais vivenciadas pelos bebês, além de possuir um recorte diferente na idade das crianças participantes. 
Neste sentido, nossa dissertação está estruturada da seguinte forma: no capítulo “Tempo, Tempo, Tempo, Tempo - Referencial Conceitual” apresentamos a discussão contemporânea sobre as configurações do tempo, tendo como base autores como Withrow (1993) e Elias (1998), que nos atentam para a construção social do tempo. Recorremos também a Castells (1999) o qual, a partir do campo sociológico contemporâneo, discute as configurações do tempo para sociedade atual, denominada por ele como sociedade em rede. Ainda, nesse capítulo, passamos a descrever como essas configurações do tempo afetam os bebês participantes de nossa pesquisa, tendo como foco as duas principais instituições sociais responsáveis pela primeira infância, quais sejam: a creche e a família. Apresentamos brevemente um recorte histórico das mudanças que essas duas instituições passaram ao longo do tempo. Vale destacar que não apresentamos uma teoria à qual nos filiamos, mas conceitos que nos ajudaram a compreender e circunscrever nosso objetivo de pesquisa.

No capítulo "Tempo, Entro Num Acordo Contigo - Percursos da Pesquisa" apresentamos o caminho metodológico, isto é: quem foram os participantes, quais os instrumentos foram utilizados - Diário do Uso do Tempo e entrevistas -, breve discussão sobre a ética em pesquisa com crianças e o corpus da pesquisa.

No capítulo “Tempo, Ouve Bem O Que Te Digo - Análise”, discutimos os dados, tomando Erving Goffman como referencial conceitual, isso porque deu destaque em sua obra para as interações sociais. Afirmamos que a maior parte do tempo dos bebês é utilizada em interações e que estas se configuram em alguns casos de forma similar ou não dentro dos diferentes contextos sociais, nesse caso, creche e família. Ao desdobrar os dados sobre interação, exploramos as situações sociais de sono, alimentação e higiene, sintetizadas na categoria cuidados e brincadeira. Por fim, "Considerações Finais" sintetizam os principais achados deste trabalho. 


\title{
2 TEMPO, TEMPO, TEMPO, TEMPO - REFERENCIAL CONCEITUAL
}

\author{
O Tempo perguntou ao Tempo \\ Quanto Tempo o Tempo tem \\ O Tempo respondeu ao Tempo \\ Que o Tempo tem tanto Tempo \\ Quanto tempo o Tempo tem \\ (Autor desconhecido)
}

O trava-língua, oriundo da sabedoria popular, explicita a dificuldade de definição do tempo. O tempo pode ser definido sob diferentes perspectivas. Nesse capítulo exemplificaremos brevemente algumas perspectivas e nos centraremos na dimensão social.

O dicionário Aulete Digital descreve o tempo como:

1. Aquilo que é medido em horas, dias, meses ou anos; período; duração: Quanto tempo leva daqui até lá? Essa camisa durou muito tempo;

2. Época, lapso de tempo futuro ou passado: Naquele tempo íamos a mais festas: Quando me chegar o tempo da velhice;

3. Oportunidade ou circunstância disponível para a realização de algo: Era tempo de safar-me daquele incômodo, saí.

É possível ainda encontrar outras definições ligadas à música, à geografia, à história, à gramática, à cronologia, ao clima, aos esportes etc. Marques e Menna-Barreto (1990) afirmam que a dimensão temporal pode ser discutida sob diversas perspectivas, como a biológica, a filosófica ou a cultural.

Segundo Carvalho (2012), existem duas grandes perspectivas conflitantes quando se aborda o tempo: a objetivista e a subjetivista:

\footnotetext{
A primeira evoca um "tempo objetivo", que se vincula ao tempo da natureza ou do mundo, ao tempo cosmológico ou físico, em suma, ao tempo das ciências; enquanto a segunda, por sua vez, defende um "tempo subjetivo", que se associa ao tempo da consciência ou do espírito (ou da alma), ao tempo psicológico ou fenomenológico, em resumo, ao tempo vivido (CARVALHO, 2012, p. 1, grifos do autor).
}

Carvalho (2012) afirma que a origem dessa divisão inicia-se com o pensamento de Aristóteles e Santo Agostinho. Para Aristóteles o tempo encontrava-se associado ao 
movimento e para Santo Agostinho o tempo estava relacionado a alma. A partir do século $\mathrm{XX}$ as diversas disciplinas passam questionar essa divisão buscando superá-la.

Nobert Elias (1998) por meio de 46 breves ensaios propõe alternativas para superação da compreensão do tempo entre objetivismo e subjetivismo. Elias (1998) inicia sua análise a partir da natureza simbólica do tempo, pois de acordo com o autor o tempo é "uma característica fundamental da experiência humana" (ELIAS, 1998, p. 17). Para o autor a aquisição gradual de conceitos temporais pode estar correlacionada com o desenvolvimento do uso da linguagem. Segundo Elias, "nossas ideias de tempo não são inatas nem automaticamente aprendidas, e sim construções intelectuais que resultam da experiência e da ação" (ELIAS, 1998, p.18). Assim, a perspectiva de tempo adotada em seu trabalho é a do tempo social.

Tabboni e Sue também discorrem sobre a concepção de tempo como construção social. Tabboni (2006, apud CARDOSO, 2009) afirma que o tempo faz parte de uma obra coletiva da sociedade. Este possui a marca da sociedade que lhe dá vida e que lhe sustenta, estabelecendo hierarquias e valores. Já para Sue (1994, apud CARDOSO, p. 29) “[...] a noção de tempo constitui-se de acordo com a consciência histórica dos atores sociais em um dado período".

Nesse sentido, faz-se necessário compreender como o tempo tornou-se um símbolo universal praticamente inquestionável. Whitrow (1993) mostra, em sua análise histórica, que a noção de dia dividido em horas, minutos e segundos é uma construção social resultante da experiência e da ação dos seres humanos. Para ele, o que distingue as sociedades contemporâneas de seus antepassados é a crescente consciência do tempo.

Na Idade Média, a sociedade era mais estática e hierárquica, e a noção de tempo era uma ideia solta, com alguns eventos importantes (comemorações religiosas, feiras, chegada das estações) os quais eram utilizados como marcadores temporais e a vida diária passava desligada da noção exata de tempo (CASTELLS, 1999). Os medidores de tempo estavam baseados nas observações dos astrônomos.

Já no século XVII, chegou-se a uma grande precisão na medição do tempo em função da invenção do relógio mecânico, o que influenciou o próprio conceito de tempo, dado que esse instrumento podia funcionar de modo uniforme e contínuo por diversos 
anos. Isso corroborou a crença na homogeneidade e continuidade do tempo. No século XVIII, surge um espírito otimista baseado na prospectiva em relação ao tempo futuro.

O período de 1750 e 1900 é caracterizado como o de maior fé no progresso (WHITROW, 1993). Nesse contexto, a duração e organização da jornada de trabalho ganha grande importância. Busca-se uma administração eficiente do tempo e Ford associa o trabalho ao consumo, defendendo que os trabalhadores gastassem mais tempo de suas vidas com o trabalho para que pudessem consumir (CARDOSO, 2009).

Para Tabboni (2006, apud CARDOSO, 2009, p. 37) a equação "tempo igual a dinheiro" é o símbolo mais forte do tempo totalmente transformado em mercadoria, reduzido a uma coisa racionalizada. Assim, o tempo da experiência é substituído pelo tempo estandardizado, no qual uma hora representa uma duração do tempo mensurável pelo relógio, qualquer que seja a situação da vida humana.

Castells (1999) assume que, na década de 1980, a desregulamentação global do sistema financeiro, a disponibilidade de novas tecnologias da informação e novas técnicas de gerenciamento do mercado transformaram a natureza dos mercados de capitais alterando a lógica do tempo e estabelecendo o seu funcionamento em tempo real. Ainda que a análise do tempo seja baseada no capital, os impactos da sua alteração são cada vez mais sentidos na vida diária em todo o mundo. O autor afirma que o tempo passa a ser gerenciado como um recurso e não mais como uma maneira cronológica linear. Isso porque o sistema de gerenciamento flexível da produção exige uma temporalidade flexível, ou seja, o ciclo de produção depende da sua capacidade de aceleração e desaceleração. Essa exigência de flexibilidade influencia diretamente a organização temporal dos indivíduos.

Ainda que a sociedade busque adotar as características do tempo abstrato para todos os tempos sociais, e mesmo que o tempo de trabalho tenha ocupado um espaço cada vez maior, nenhuma sociedade jamais teve uma uniformidade completa e uma concepção única do tempo (CARDOSO, 2009).

Os gregos, por exemplo, utilizavam três palavras diferentes para referirem-se ao tempo: 
[...] chrónos designa a continuidade do tempo sucessivo [...]. Kairós, que significa 'medida', 'proporção', e, em relação com o tempo, 'momento crítico', 'temporada', oportunidade [...]. E Aión que designa, já em seus usos mais antigos, a intensidade do tempo da vida humana, um destino, uma duração, uma temporalidade não numerável nem sucessiva, intensiva (KOHAN, 2004, p. 54).

Ou seja, o tempo não se concretiza de maneira uniforme em todas as esferas da vida. Chrónos denota a rigorosidade de um movimento sucessivo e lógico do mundo real; Kairós a medida; e Aión apresenta-se no campo das ideias e das experiências sem corresponder a uma determinada sequência. Nesse sentido, a partir do fragmento 52 de Heráclito, Kennedy e Kohan (2008) tratam o tempo da criança que, nesse caso, aparece em posse de Aión, enquanto o tempo do adulto é o Chrónos.

Kennedy e Kohan (2008) destacam ainda que o fragmento parece querer dizer, entre outras coisas, que o tempo de vida não é apenas uma questão de movimento numerado, mas também uma forma de experimentar a própria vida. E por se tratar de experiência, são as crianças os seres que mais experimentam, ousam, inventam, criam hipóteses, detendo assim o poder de utilizar seu tempo para além da rigidez marcada nos ponteiros do relógio.

A partir desse olhar a infância poderia não ser reduzida somente a um período de tempo, como de uma idade a outra, mas como a vivência do tempo não-cronológico, Aión, que valoriza a intensidade de duração e apresenta "[...] uma possibilidade, uma força, uma intensidade [...] e não, como geralmente se pensa, uma ausência de poder, mas um modo singular de praticar poder." (KENNEDY; KOHAN, 2008, p. 7).

A partir das discussões de Kennedy e Kohan (2008) podemos afirmar que as crianças vivem o tempo de maneira diferente dos adultos, logo elas também atribuem ao tempo um sentido diferente. Christensen (2002) desenvolveu uma pesquisa com crianças de dez e onze anos na Inglaterra para descobrir o que significava para elas a qualidade de tempo familiar. Christensen (2002) afirma que a qualidade de tempo abordada pelas crianças remete à importância do conteúdo e do contexto em que este transcorre, isto é, "[...] as noções de tempo para as crianças estão situadas nos processos através dos quais a família, a escola e a vida profissional ocorrem em uma base diária" (CHRISTENSEN, 2002, p. 82, tradução nossa). Nesse sentido, as crianças não compartimentam seu tempo e espaço fazendo distinção do que vivem só em casa ou só na escola, mas indicam que a qualidade de seu tempo é uma experiência contínua de Aión no dia a dia. 
Dado que o objetivo desta pesquisa é o uso do tempo no cotidiano de bebês, passaremos a discutir, na próxima seção, como o tempo social é organizado nas duas principais instituições sociais contemporâneas responsáveis pelo cuidado/educação de bebês, quais sejam: família e creche. Destacamos essas duas, pois a família, em geral, é o ponto de partida para as relações dos bebês com o resto do mundo. Assim, como afirma Nunes (2003) a integração da criança na sociedade inicialmente é feita em nível micro, sendo em geral, no grupo familiar mais próximo. E a creche, dadas às configurações sociais atuais, tem ganhado importância como instituição que partilha os cuidados/educação de bebês com as famílias.

Além disso, é no entrecruzamento dessas instituições que os bebês desenvolvem suas ações construindo suas culturas. Para Corsaro (2011), as crianças participam desde pequenas de uma série de espaços institucionais, como a família, a comunidade imediata, a igreja, a creche, etc. A família é justamente a responsável pela ligação entre o bebê e as outras instituições sociais.

A opção de conduzir a pesquisa no contexto da creche e da família também devese a busca por conhecer o uso do tempo dos bebês de uma forma integral, ou seja, conhecer o tempo do bebê não apenas enquanto filho que integra a dinâmica familiar, nem apenas como "aluno", mas como indivíduo que integra o "hibridismo do mundo social" (PROUT, 2010), o bebê enquanto participante da dinâmica da sociedade ocupante de diversos espaços.

\subsection{TEMPO, FAMÍLIA E CRECHE}

Ariès (1981), em seus estudos da iconografia da Idade Média e Moderna, afirma que a noção de família foi sendo forjada ao longo da história. A partir da análise das gravuras do século XVI é que o autor começa a perceber a representação da família, baseada na propriedade e na linhagem. A partir do século XVI, a representação de família se aproxima à perspectiva moderna, e surgem novas personagens nas gravuras: a mulher, o grupo de vizinhos, os companheiros e a criança. Os laços passam a se constituir pela ligação sanguínea e não apenas pela linhagem, desenvolvendo o sentimento de família pautado na privacidade e na intimidade, estreitando os laços entre cônjuges e entre pais e 
filhos. Segundo Szymansky (2002, p. 24), é nesse contexto que emerge o modelo de família nuclear burguesa:

Com o surgimento da escola, da privacidade, a preocupação de igualdade entre os filhos, a manutenção das crianças junto aos pais e o sentimento de família valorizado pelas instituições (principalmente a Igreja), no início do século XVIII, começa a delinear-se a família nuclear burguesa.

A vida familiar estendeu-se a quase toda a sociedade, a tal ponto que as pessoas se esqueceram de sua origem aristocrática e burguesa (ARIÈS, 1981). Nesse contexto, passou a ser comum as generalizações em torno dos papéis sociais de homem, de mulher e de filhos. Bilac (2002) argumenta que a variabilidade histórica da instituição familiar não permite uma generalização ou um conceito geral.

As Ciências Sociais vêm discutindo o tema da família sob uma diversidade de abordagens. A sociologia funcionalista considera a família uma agência socializadora "[...] cujas funções concentram-se na formação da personalidade dos indivíduos" (BRUSCHINI, 1989, p. 2). Para a teoria marxista, a família está ligada ao sistema de produção e reprodução da sociedade capitalista. Já a antropologia questiona a naturalização da família e a tem conceituado como "[...] grupo de indivíduos ligados por elos de sangue, adoção ou aliança socialmente reconhecidos e organizados em núcleos de reprodução social” (BRUSCHINI, 1989, p. 4).

Todavia, criou-se nas sociedades ocidentais modernas um modelo predominante de família: grupo composto por marido, mulher e filhos. Esse modelo vem sendo debatido e questionado na contemporaneidade. Goldani (1993) argumenta que a família tanto é vista como instituição de confiabilidade como instituição em desagregação/crise. Afirma que há mudanças no comportamento das famílias patriarcais, mas isso não significa que elas estejam desaparecendo.

Fontoura et al. (2010), ao analisarem os dados do Instituto Brasileiro de Geografia e Estatística (IBGE), especialmente da Pesquisa Nacional por Amostra de Domicílios (PNAD), afirmam que a tendência que pode ser observada em relação às composições familiares é ainda a do casal com filhos, contudo, sua importância tem decrescido ao longo das últimas décadas.

Em 1993, correspondia a 62,6\% das famílias brasileiras; em 2008, caracterizava $48,2 \%$ delas. Paralelamente, ganham importância as famílias 
monoparentais e uni-pessoais, e, ainda que timidamente, vem crescendo o número de casais sem filhos. Em todos esses modelos, cada vez mais mulheres são identificadas como principais responsáveis pela família: em 1993, 22,3\% dos arranjos familiares eram chefiados por mulheres; em 2008, chegamos a $35 \%$. Chama ainda mais atenção o aumento significativo de famílias nas quais as mulheres, mesmo com cônjuge, são identificadas como pessoa de referência. Entre 1998 e 2008, o número de arranjos familiares com cônjuge sendo chefiados por mulheres subiu de 2,4\% para 9,1\% (FONTOURA et al., 2010, p. 14).

O papel histórico e cultural das mulheres sempre esteve ligado aos cuidados com a casa e com a família. Há uma mudança na configuração dos arranjos familiares que, no entanto, não significa uma desobrigação das mulheres com as tarefas de cuidado materno, ao mesmo tempo implica na sua inserção no mercado de trabalho de forma precarizada. Para Fontoura et al. (2010), as mulheres não só têm maiores dificuldades para encontrar uma posição no mercado de trabalho, como também de permanecer nele. Para os autores, as mulheres, de forma geral, auferem, na média, rendas inferiores às dos homens.

No entanto, algumas mudanças podem ser observadas nesse cenário. Há uma queda do tempo despendido nos afazeres domésticos tanto para homens como para mulheres. Segundo Fontoura et al. (2010), em 2001 estes gastavam, respectivamente, 10,9 e 29 horas semanais com trabalhos domésticos; já em 2008 gastavam 9,7 e 23,9 horas, respectivamente. Esse fato se deve às novas tecnologias e aos novos hábitos (como almoçar fora de casa), além do menor número de filhos, ampliação do acesso a bens e serviços, tais como água encanada, saneamento e eletrodomésticos, que facilitam a vida de quem responde pelo trabalho doméstico.

As políticas públicas brasileiras ainda são configuradas no trabalho reprodutivo das mulheres. Pinheiro, Galiza e Fountura (2009) mostram que os benefícios previstos por essas políticas enfatizam prioritariamente os direitos reprodutivos das mulheres, oferecendo poucas possibilidades aos homens de se comprometerem com o exercício da paternidade responsável. As políticas públicas brasileiras ainda ignoram a existência de famílias homoafetivas, monoparentais e masculinas.

Um dos desafios aos indivíduos na atualidade é conciliar o tempo entre família, trabalho, compromissos sociais, lazer, etc. Zeiher (2007) trata desse aspecto em seu estudo, relacionando os impactos da flexibilização do tempo nas configurações da família e infância alemã. A autora discute sobre negociações que existem entre os tempos dos pais, as demandas em seus trabalhos, os tempos dos filhos e o tempo da instituição de 
Educação Infantil. No estudo, o modelo de família abordado foi o parental, em que tanto pai como mãe trabalham fora e participam da divisão das tarefas na casa. Zeiher (2007) afirma que, nesse modelo de família, há uma nova tendência just in time, onde o tempo é comandado, principalmente, pelas necessidades que vão surgindo, ou seja, “[...] somente onde se deve planeja-se o tempo, para o resto as específicas ações surgem das situações, por necessidade ou segundo inclinações" (ZEIHER, 2007, p. 67).

Nesse contexto, ocorreu um deslocamento do cuidado dos filhos para fora da família e as crianças passam mais tempo na escola, em lugares de assistência e em instituições do tempo livre. Assim, múltiplas instituições participam alternativamente do cuidado das crianças e, portanto, elas experimentam uma diversidade de uso do tempo.

No cenário brasileiro, o atendimento oferecido em creches tem grande importância. Em 2001, o atendimento de crianças de 0 a 3 anos em creche era de 13,8\%, passando para 27,9\% em 2013. É possível visualizar esta mudança no gráfico1:

Gráfico 1 - Porcentagem de crianças de 0 a 3 anos na Educação Infantil

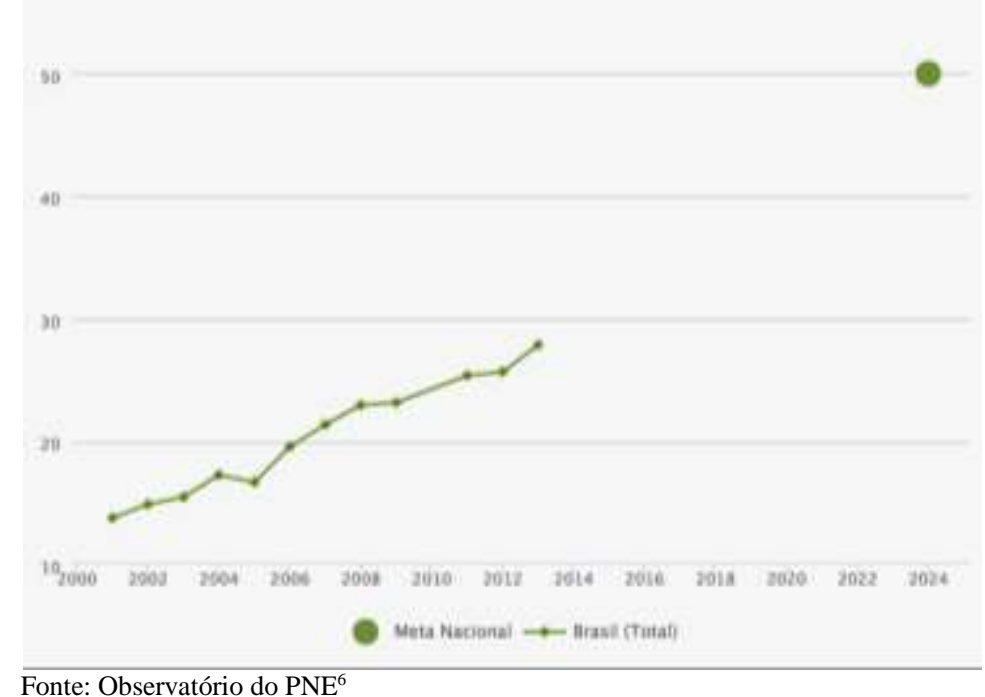

Já o atendimento de crianças de 4 a 5 anos em pré-escolas (Gráfico 2) em 2001 era de $66,4 \%$ e passou para $87,9 \%$ em 2013.

\footnotetext{
${ }^{6}$ http://www.observatoriodopne.org.br/metas-pne/1-educacao-infantil/indicadores
} 
Gráfico 2 - Porcentagem de crianças de 4 e 5 anos na Educação Infantil

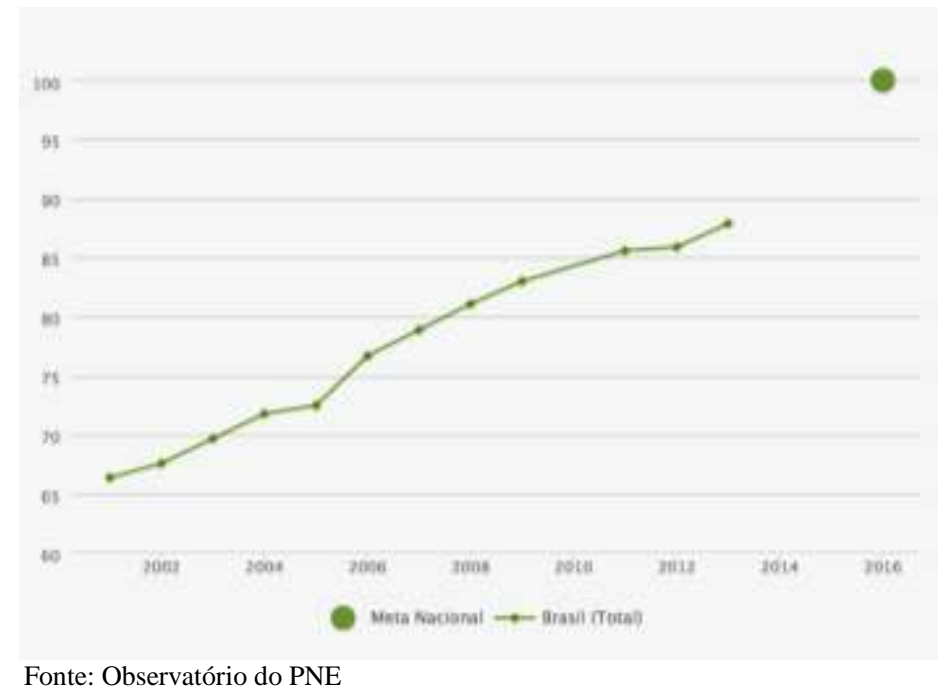

Vale destacar que a meta do Plano Nacional de Educação (PNE, 2014) é universalizar, até 2016, a pré-escola para as crianças de 4 a 5 anos de idade e ampliar a oferta de atendimento em creches de forma a atender, no mínimo, $50 \%$ das crianças de até 3 anos até o final da vigência do PNE em 2024. A partir dos dados do Censo Escolar (MEC/ INEP, 2014), nota-se que o número total de matrículas nas creches em 2014 foi de 2,9 milhões e da pré-escola foi de 4,9 milhões.

Segundo Batista (1998, p. 3),

[...] a creche vem se constituindo como um espaço de educação coletiva no mundo contemporâneo, cuja relevância não é possível ignorar. Se em outros tempos cabia à família cuidar e inserir seus filhos pequenos no universo da cultura, hoje com o processo crescente de industrialização e urbanização, com a inserção cada vez mais intensa da mulher no mercado de trabalho, parece ser a creche que cada vez mais partilha com a família esta tarefa.

A creche afeta e é afetada por essa estruturação do tempo. No Brasil, um recente debate acerca dessa complexa rede de relações pode ser observado na reinvindicação por funcionamento de creche no período noturno e sem pausa para recesso ou período de férias. O Tribunal de Justiça do Estado de São Paulo determinou, no decorrer de 2011, que as creches municipais deveriam permanecer abertas nos períodos de férias e recesso escolar ${ }^{7}$ com a justificativa de que essa medida poderia garantir a segurança das crianças enquanto os pais trabalhavam. Outras cidades também passaram a adotar esse tipo de

\footnotetext{
${ }^{7}$ http://revistaepoca.globo.com/Revista/Epoca/0,EMI217315-15215,00.html
} 
atendimento. Na época da decisão judicial, algumas entidades e órgãos ligados à educação se pronunciaram. O Conselho Nacional de Educação elaborou um parecer aprovado ${ }^{8}$ pelo Ministério da Educação que se mostrava contrário à medida judicial e orientava que todas as creches do país não ofertassem atendimento durante as férias, alegando que não deveriam ser vistas como unidades assistencialistas.

Ainda que tenha ocorrido essa resistência em relação ao atendimento no período de férias e recesso, o atendimento no período noturno é uma realidade em muitos municípios. Segundo dados do Censo 2012 (MEC/INEP, 2013), esse atendimento se concentra na região Sul. Em municípios como Presidente Getúlio, em Santa Catarina o atendimento noturno é realizado em escolas próximas a grandes empresas, as quais possuem turnos variados de trabalho; em Pomedore, Santa Catarina o atendimento noturno é prestado aos pais que comprovam a necessidade ${ }^{9}$.

A história da creche no Brasil está vinculada às demandas sociais e aos direitos das crianças. De acordo com Kuhlmann Jr. (2010), as instituições de Educação Infantil foram difundidas internacionalmente a partir da segunda metade do século XIX. No Brasil, as duas primeiras décadas do século XX foram marcadas pela implementação das creches de caráter assistencialista e três influências podem ser identificadas na composição de forças que participaram da elaboração das políticas: a médico-higienista, a jurídico-policial e a religiosa.

Segundo Kuhlmann Jr. (2010), as creches brasileiras passaram por um processo de expansão a partir do final da década de 1970, a qual pode ser definida como um novo momento na história da Educação Infantil. Esse novo período, segundo o autor, é impulsionado pela crescente presença da mulher no mercado de trabalho. De acordo com Faria (2006), os movimentos feministas, sindicalistas e de esquerda influenciaram a reivindicação por creches.

\footnotetext{
${ }^{8}$ Parecer CNE/CEB n ${ }^{\circ} 8 / 2011$

${ }^{9}$ Fonte: http://ultimosegundo.ig.com.br/educacao/2014-06-27/demanda-por-creches-noturnas-cresce-44em-cinco-anos.html
} 
Nos anos 1970, a luta ocorreu pelo direito das mulheres terem acesso a esse serviço, enquanto nos anos 1980, o próprio movimento feminista defendeu as creches como direito das crianças pequenas e não só das mães trabalhadoras. De acordo com Cerisara (2002) os anos 1980 marcam o início de uma reorientação de enfoque, da criança como objeto de tutela para a criança como sujeito de direitos, legalmente isso é estabelecido pela Constituição de 1988. Assim, a Educação Infantil passou a ser um dever do Estado e um direito da criança. O Estatuto da Criança e do Adolescente (ECA) de 1990, é outro marco legal que avança nessa direção de afirmar os direitos das crianças. E com a Lei de Diretrizes e Bases (LDB), Lei nº 9.394/96, há o estabelecimento da Educação Infantil como primeira etapa da Educação Básica.

Campos, Fülllgraf e Wiggers (2006) afirmam que apesar dos avanços legais e a proliferação de saberes sobre as crianças, o atendimento na Educação Infantil ainda tem baixa qualidade. Segundo as autoras, os estudos realizados sobre o funcionamento das instituições de Educação Infantil indicam para as más condições dos prédios e equipamentos, para falta de materiais pedagógicos, para a falta de formação dos educadores e dificuldades de comunicação com as famílias.

Além, destas dificuldades estruturais há também dificuldades de adequação da prática pedagógica as novas formas de compreender as crianças não mais como ser imaturo, mas como seres competentes, como atores sociais. Diversos estudos têm mostrado a persistência de práticas pedagógicas baseadas na lógica do adulto. Batista (1998), em seu estudo sobre o que é proposto e o que é vivido na creche, afirma que há uma tendência de se adotarem rotinas rígidas, homogeneizadas e hierarquizadas, fazendo com que a organização do tempo-espaço seja compreendida e estruturada para sujeitosalunos e não para sujeitos-crianças. Segundo a autora, essa lógica dificulta o trabalho pedagógico a ser desenvolvido, “[...] abreviando as possibilidades das crianças viverem com intensidade suas pluralidades de saberes, sua diversidade de raça, credo e gênero, de sentimentos, desejos e fantasias" (BATISTA, 1998, p. 4). Segundo Guimarães (2011, p. 36) a realidade da creche é marcada pelas rotinas automatizadas de alimentação, higiene e sono, como também pelo modelo disciplinar, pela individualização, isolamento dos corpos e mecanização das ações.

Batista (1998, p. 11-12) afirma que o que acaba acontecendo na creche é que o tempo determina a atividade e não o contrário: 
[...] não é a atividade que determina o tempo, mas o tempo que a determina [...]. Neste sentido, não importa se a atividade está sendo significativa para as crianças, mas sim tentar manter a sequência para garantir a pontualidade dos horários predeterminados.

Assim, nesse cenário de diferentes demandas de tempo para famílias, creche e bebês, é que propomos o presente estudo. Buscamos responder a pergunta: Como é de fato o uso do tempo no cotidiano de dois bebês?

Nos próximos capítulos descrevemos qual foi o percurso metodológico adotado, as categorias analíticas e as considerações que chegamos acerca do objetivo de pesquisa. 


\section{TEMPO, ENTRO NUM ACORDO CONTIGO - PERCURSOS DA PESQUISA}

A água da panela parece que não vai ferver, seu eu a observar.

(Provérbio inglês)

O provérbio inglês trata da percepção da passagem do tempo para um indivíduo. Vários fatores podem interferir nessa percepção: se enquanto o indivíduo espera acontece algo, se nesse intervalo o tempo é homogêneo, ou se algo está para acontecer, mas não acontece. Esses diferentes elementos vão fornecer diferentes marcadores para o indivíduo e interferir na sua percepção da passagem do tempo. Segundo Ades (2002), a estimativa de duração depende da perspectiva em que se coloca a pessoa durante a sua passagem. $\mathrm{O}$ relógio, instrumento social, proporciona a essa observação uma medida objetiva e homogênea, contudo a percepção do indivíduo sobre o transcorrer do tempo vai depender de vários elementos. Inspirados nesse provérbio inglês, abrimos a discussão sobre a metodologia adotada nesta pesquisa. Informamos quais foram as lentes e os caminhos adotados para cumprir nosso objetivo de pesquisa.

A pesquisa foi desenvolvida com dois bebês, um menino e uma menina, da turma inicial de uma instituição pública de Educação Infantil do Distrito Federal e seus respectivos responsáveis, em ambos os casos, suas mães. De acordo com Goldenberg (2004), a representatividade dos dados na pesquisa qualitativa em Ciências Sociais está relacionada à capacidade de possibilitar a compreensão do significado e a "descrição densa" dos fenômenos estudados em seus contextos e não à sua expressividade numérica.

A seleção das participantes deu-se por conveniência e intencionalidade. De acordo com Gil (2008, p. 94), a seleção por conveniência é adequada para estudos qualitativos, quando o "[...] pesquisador seleciona os elementos a que tem acesso". E, Creswell (2010) escreve que a seleção intencional significa que o pesquisador vai escolher os indivíduos, o local e os materiais que irão ajudá-lo a entender o problema e as questões de pesquisa.

No ano de 2013, o Distrito Federal (DF) possuía apenas duas instituições públicas que ofertavam atendimento educacional às crianças a partir de quatro meses de idade, localizadas em duas Regiões Administrativas distintas. Assim, para escolhermos a instituição na qual conduziríamos a pesquisa, utilizamos o critério da intencionalidade, 
ou seja, de que a creche possuísse consolidado o atendimento aos bebês, e o da conveniência, neste caso, o fato de uma equipe do GIPI já estar trabalhando na instituição.

Na instituição selecionada, o Berçário I atendia, no ano de 2013, 21 crianças, sendo 13 meninos e 8 meninas, com idade entre 9 e 18 meses na data da primeira geração de dados (25/09/2013). A seleção dos sujeitos da pesquisa seguiu o critério da menor idade do bebê - pois nos interessava contribuir para o preenchimento da lacuna em relação aos estudos com crianças pequenas - e também considerou a pessoa que se declarava responsável pela criança. Foram realizados três convites para a participação da menina e um convite para a participação do menino.

Apresentamos a seguir a caracterização da instituição e dos participantes da pesquisa, os instrumentos utilizados, o corpus da pesquisa e a ética na pesquisa.

\subsection{INSTITUIÇÃO E PARTICIPANTES}

A pesquisa foi desenvolvida no contexto de uma instituição pública de Educação Infantil do DF que ofertava atendimento em creche e pré-escola em tempo integral (10 horas). As matrículas para a creche seguiam critérios socioeconômicos, uma vez que havia uma demanda maior que a oferta. Até o ano de 2014, o DF possuía apenas uma instituição pública que ofertava atendimento a crianças a partir de 4 meses de idade.

Segundo dados do Censo da Educação Básica (MEC/INEP, 2013), existia, no DF, 25.498 crianças matriculadas em creches e 58.365 crianças matrículas na pré-escolas, distribuídas na rede pública e privada. O atendimento na rede pública em creche correspondia a 6,4\% (1.630 matrículas) ${ }^{10}$ e na pré-escola a 55,7\% (32.497 matrículas). Já na rede privada as matrículas na creche correspondiam 93,6\% (23.868 matrículas) e na pré-escola 44,3\% (25.868 matrículas).

A SEDF estabeleceu política de conveniamento para atendimento da demanda de Educação Infantil. Em 2013, havia 51 instituições conveniadas com a SEDF. Segundo

\footnotetext{
${ }^{10}$ Número de matrículas que correspondia, principalmente, ao atendimento de crianças de 2 e 3 anos.
} 
dados do Censo Escolar do DF, o atendimento em creche correspondeu a 6.492 matrículas, enquanto na pré-escola foram 3.497 matrículas. O conveniamento com as instituições privadas sem fins lucrativos de Educação Infantil até 2010 era responsabilidade da Secretaria de Estado de Desenvolvimento Social e Transferência de Renda (SEDEST). Somente em 2011 o conveniamento passou a ser integralmente de responsabilidade ${ }^{11}$ da SEDF, que buscou atender ainda que tardiamente o disposto no Art. 89 da LDB, que determina que as creches e pré-escolas façam parte do sistema de ensino.

Nesse cenário, a instituição locus dessa pesquisa atendia, em 2013, 192 crianças, sendo 97 crianças na creche e 95 crianças na pré-escola. A equipe era composta por 69 funcionários: 7 pessoas na equipe da direção (1 diretora, 1 vice-diretora, 1 supervisora, 1 chefe de secretaria e 3 coordenadoras pedagógicas); 24 professoras; 11 monitores; 2 porteiros; 8 profissionais de serviços gerais; 3 vigilantes; 4 cozinheiras e 10 educadores sociais voluntários.

Os profissionais responsáveis pela turma do Berçário I eram duas professoras, uma para cada período de 5 horas. A jornada de trabalho de cada uma totalizava 25 horas semanais, diretamente com as crianças, e 15 horas dedicadas à formação continuada, planejamento e reuniões com coordenação pedagógica, constituindo-se assim em 40 horas de trabalho por semana. Além das professoras, eram também responsáveis pela turma três monitores que trabalhavam em jornada integral. Contudo ocorreram algumas mudanças no decorrer do ano e, em cada uma das ocasiões de geração de dados, foram encontrados adultos diferentes responsáveis pelas crianças.

As duas professoras do Berçário I faziam parte do quadro de professores temporários da SEDF, e, para ambas, foi a primeira experiência profissional com uma turma de Berçário. A formação exigida pela SEDF para contratação de professores temporários é curso de graduação de nível superior em Pedagogia com habilitação em séries iniciais e/ou em Educação Infantil ou curso de licenciatura plena em Normal Superior. Já a formação exigida para os monitores é o Ensino Médio.

${ }^{11}$ Portaria Conjunta $N^{\mathrm{o}}$ 3, de 11 de Março de 2011. 
O espaço do Berçário I era constituído por um banheiro, sala principal, sala com berços e solário. Na sala principal havia um tapete de EVA que cobria quase todo o piso, uma barra no meio da sala para ajudar no apoio dos bebês que estavam começando a andar, algumas cadeiras do tipo bebê conforto que ficavam no fundo da sala, um pequeno armário para uso das professoras e uma televisão. A alimentação dos bebês ocorria na sala principal, com a utilização de alguns cadeirões.

A rotina da turma estava estabelecida da seguinte forma: 7h20min - início da entrada, 8h30min - café da manhã, 9h30min - banho e/ou troca de fraldas, 10h30min almoço, 11h30min - momento para descanso, 13h - lanche, 15h30min - jantar, 17h30min - saída.

Participaram da pesquisa os bebês Augusto ${ }^{12}$ e Clarice e suas respectivas mães Isadora e Carolina, conforme se observa no Quadro 1.

Quadro 1 - Apresentação dos participantes

\begin{tabular}{|c|c|}
\hline Participante & Idade \\
\hline Criança: Augusto & 11 meses \\
\hline Mãe: Isadora & 32 anos \\
\hline Criança: Clarice & 18 meses \\
\hline Mãe: Carolina & 26 anos \\
\hline Fonte: Corpus da pesquisa
\end{tabular}

Augusto, com 11 meses na data da primeira geração dos dados (25/09/2013), frequentava a creche desde abril de 2013. Morava com o pai, a mãe e a irmã em um bairro central de Brasília. Isadora, mãe de Augusto, tinha 32 anos, possuía ensino superior completo, estava realizando curso de pós-graduação e era bancária.

Clarice, com 18 meses na data da primeira geração dos dados (25/11/2013), frequentava a creche desde fevereiro de 2013. Morava com o pai, a mãe e o irmão em

\footnotetext{
12 Para preservar a identidade dos participantes na pesquisa, exigência do Comitê de Ética em Pesquisa (CEP/IH/UnB), todos os nomes foram substituídos por nomes fictícios.
} 
uma Região Administrativa do DF. Carolina, mãe de Clarice, tinha 26 anos, possuía ensino fundamental incompleto e era empregada doméstica.

Destacamos as informações referentes às mães, pois estas participaram da geração dos dados, tendo sido responsáveis pelo preenchimento do Diário do Uso do Tempo, assim como participaram das entrevistas.

\subsection{INSTRUMENTOS}

Por se tratar de uma pesquisa focada no tempo, para a geração de dados foi utilizado o Diário do Uso do Tempo e entrevistas subsequentes. O Diário do Uso do Tempo consiste em uma técnica para gerar informações sobre o cotidiano dos indivíduos (TEIXEIRA; CRUZ, 2006b) nas seguintes dimensões: diversidade, variedade, natureza e duração das atividades (primárias e secundárias) ${ }^{13}$; contexto de vida (quantidade e tempo passado em cada um); contexto social de interação (em direção direta ou apenas disponível), permitindo perceber com quem o sujeito está, quanto tempo, em que local e fazendo o quê.

Em geral, as pesquisas que utilizam esse instrumento tem caráter quantitativo, conforme observado por Larson e Verma (1999). Esses autores revisaram os estudos sobre a utilização do tempo de crianças e adolescentes em todo o mundo e apresentam um esboço geral das experiências diárias de socialização. O método de registro dessas pesquisas documenta em horas e/ou minutos o período de 24 horas, tanto em dias de semana quanto no final de semana.

O presente estudo construiu um diário inspirado no modelo proposto pelo Harmonised European Time Use Surveys - HETUS (EUROSTAT, 2004) ${ }^{14}$. Nesse instrumento, as atividades são registradas em um quadro com intervalos de tempo prédefinidos de 10, 15, 20 ou 30 minutos, conforme a pertinência para o estudo em pauta.

\footnotetext{
${ }^{13}$ Atividade primária consiste na atividade principal, o que o sujeito estava fazendo. Atividade secundária diz respeito ao que o sujeito estava fazendo concomitante à atividade primária.

14 Trata-se de um consórcio dos Institutos Nacionais de Estatística dos países da União Europeia que busca harmonizar as pesquisas sobre o uso do tempo, de forma a tornar os estudos nacionais mais facilmente comparáveis. Fonte: https://www.h2.scb.se/tus/tus/Default.htm
} 
Além desse instrumento, utilizamos como referência os diários usados nos estudos de Teixeira e Cruz (2006a), Christensen e James (2008) e Minkoff e Riley (2011), já destacados na introdução desse trabalho. Retomamos esses estudos para apresentar os instrumentos de pesquisa utilizados por eles, pois eles inspiraram a construção do nosso Diário do Uso do Tempo.

Teixeira e Cruz (2006a) adotaram uma abordagem quantitativa. Utilizaram o Diário do Uso do Tempo com crianças entre 8 e 10 anos de idade na região metropolitana do Porto, em Portugal. Nesse caso, o instrumento não foi preenchido enquanto ocorriam as atividades, mas a partir de uma entrevista em que o pesquisador solicitava à criança que descrevesse as atividades que lembrasse.

Christensen e James (2008) e Minkoff e Riley (2011) desenvolveram suas análises por meio de uma abordagem qualitativa, levando em consideração a compreensão de tempo das próprias crianças.

Christensen e James (2008) conduziram a pesquisa com crianças de 10 anos de idade que viviam em zona urbana e rural da Inglaterra. Para isso, utilizaram como instrumento um círculo vazado em uma folha branca para registro da semana. $\mathrm{O}$ instrumento tinha por objetivo facilitar o pensamento das crianças em responder a pergunta de como elas utilizavam o seu tempo durante uma semana. O registro da informação ocorreu de diferentes formas, em alguns casos as crianças preencheram o círculo enquanto estavam na presença do pesquisador em outras situações preencheram em casa com ajuda dos pais ou não, para depois discutirem com o pesquisador.

Minkoff e Riley (2011) utilizaram como instrumento metodológico uma adaptação do Diário de Uso do Tempo de adultos conjugado a desenhos para captar as informações subjetivas das crianças, de 6 e 7 anos de idade, sobre as suas rotinas diárias. Após a aplicação do Diário do Uso do Tempo, ocorreu uma entrevista detalhada com cada criança para explorar suas percepções de tempo em relação às ocupações diárias, utilizando como suporte os desenhos e uma escala de avaliação.

Percebemos que o Diário do Uso do Tempo tem sido utilizado com pessoas de todas as idades, tanto adultos quanto crianças, variando na forma de administração. 
Portanto, esse instrumento oportuniza uma interessante forma de coleta de dados sobre o cotidiano dos indivíduos.

Assim, construímos nosso Diário do Uso do Tempo. Foi possível gerar as seguintes informações: atividade desenvolvida, hora de início e fim de cada atividade, local, com quem estava durante a atividade e observações.

As informações relativas ao cotidiano das crianças foram geradas em dois momentos diferentes. Em um período de 24 horas do dia da semana em que a criança esteve presente na creche e em um período de 24 horas no final de semana. A opção por esses dois dias teve como objetivo obter uma descrição pormenorizada das atividades desenvolvidas pelos bebês.

O registro das atividades no período da creche foi realizado pela pesquisadora de forma individualizada, com uma ida a campo para cada criança. Já o registro das atividades realizadas no contexto familiar, tanto no dia da semana quanto no final de semana, foi realizado pelo responsável. Portanto, cada mãe preencheu 2 Diários do Uso do Tempo. As mães foram orientadas para que todas as atividades desenvolvidas pela criança fossem anotadas de forma detalhada no Diário, garantindo o registro no momento em que aconteciam ou no final de cada período: manhã, tarde e noite.

A seguir é apresentado o Quadro 2 que sistematiza informações sobre o responsável pelo preenchimento do Diário, o local e a data da geração dos dados de cada criança:

Quadro 2 - Data e local do preenchimento do Diário do Uso do Tempo

\begin{tabular}{|c|c|c|c|}
\hline \multirow{4}{*}{ Bebê } & Preenchimento & Local & Data \\
\hline \multirow{2}{*}{ Augusto } & Pesquisadora & Creche & $25 / 09 / 2013$ \\
\cline { 2 - 4 } & Isadora & Casa & $25 / 09 / 2013$ \\
\cline { 2 - 4 } & Isadora & Casa & $02 / 11 / 2013$ \\
\hline \multirow{2}{*}{ Clarice } & Pesquisadora & Creche & $25 / 11 / 2013$ \\
\cline { 2 - 4 } & Carolina & Casa & $25 / 11 / 2013$ \\
\cline { 2 - 4 } & Carolina & Casa & $09 / 12 / 2013$ \\
\hline
\end{tabular}

Fonte: Corpus da pesquisa 
De forma complementar, foram realizadas entrevistas com as mães. Com a entrevista, buscamos superar uma limitação do Diário do Uso do Tempo, isto é, a tendência de os sujeitos omitirem o tempo dedicado às atividades curtas relacionadas aos cuidados pessoais e às conversas entremeadas das atividades. Como registrado em outros estudos (LARSON; VERMA, 1999; CARVALHO; MACHADO, 2006) os sujeitos tendem a subestimar o tempo dedicado às atividades curtas relacionadas aos cuidados pessoais e às conversas que são intercaladas no âmbito das atividades, pois os participantes negligenciam essas informações nos seus registros. Assim, as anotações dos Diários serviram como base para o roteiro da entrevista.

\subsection{CORPUS DA PESQUISA}

Em relação ao preenchimento dos quatro Diários, no campo onde deveria ser discriminada a atividade, houve um registro de 396 atividades com um total de 83 h. Essas passaram-se em 11 espaços e houve o registro de 281 observações. Especificamos a seguir os dados para cada uma das crianças.

Os dois Diários de Augusto constituem-se em 180 atividades com um total de 16h47min, registradas no dia da semana, divididos em 138 atividades e 8h19min na creche; 42 atividades e $8 \mathrm{~h} 28 \mathrm{~min}$ no contexto familiar. Também é observável o registro de 72 atividades e $23 \mathrm{~h} 44 \mathrm{~min}$ no final de semana.

No campo do Diário destinado ao local, no dia da semana, Augusto esteve na instituição de Educação Infantil, predominantemente na sala principal do Berçário I. No período que esteve com a família, as atividades ocorreram em casa (quarto dos filhos, quarto dos pais, sala, banheiro, cozinha) e igreja. No final de semana, as atividades transcorreram em casa (quarto dos filhos, quarto dos pais, sala, banheiro, cozinha, varanda, calçada), na casa da avó (calçada), em lojas em 4 diferentes Regiões Administrativas do DF, além de espaços de lazer em duas dessas Regiões Administrativas e dentro do carro.

Augusto, enquanto esteve na creche, participou de encontros que envolveram 26 indivíduos diferentes, sendo 17 bebês presentes no dia da geração dos dados e 9 adultos: 2 professoras, 2 pesquisadoras, 4 adultos da equipe da direção e 1 monitor. Os adultos se 
revezaram ao longo do dia. No período da manhã esteve presente a professora do período da manhã, as pesquisadoras e algumas pessoas da equipe gestora, que estiveram presentes na turma do Berçário I nos momentos de maior movimentação: horário do café da manhã, troca de fraldas, banho e almoço. Nesse dia não havia monitores disponíveis no período da manhã, sendo assim a equipe gestora se revezou, não sendo observada uma presença contínua de adultos na turma. No período da tarde estiveram presentes a professora da tarde, novamente as duas pesquisadoras, o monitor e, em alguns momentos pontuais, algum membro da equipe gestora.

No contexto familiar os encontros ocorreram com alguns membros da família: pai, mãe, irmã e avó. Ocorreram também encontros com adultos e crianças que não foram especificados em seu Diário no período em que ele acompanhou a família à igreja. No final de semana, Augusto se relacionou com 9 pessoas: pai, mãe, irmã, avó, tia, prima, outra criança de sua idade e 2 amigos dos pais, além de alguns comerciantes enquanto os pais realizavam compras.

No campo observação do Diário do dia da semana foram registradas 98 observações no período em que ele esteve na creche e 29 observações enquanto esteve com sua família. Foram registradas 55 observações no final de semana. As observações complementaram informações registradas no campo atividades, bem como forneceram alguns dados do contexto. O quadro 3 sintetiza essas informações.

Quadro 3 - Dados gerados nos Diários de Augusto

\begin{tabular}{|c|c|c|c|c|c|c|}
\hline \multicolumn{7}{|c|}{ Augusto } \\
\hline & Atividade & Duração & Local & $\begin{array}{c}\text { Com quem } \\
\text { estava }\end{array}$ & Observação \\
\hline $\begin{array}{c}\text { Dia da } \\
\text { Semana }\end{array}$ & Creche & 138 & $08: 19$ & 1 & 26 & 98 \\
\cline { 2 - 7 } & Casa & 42 & $08: 28$ & 2 & 4 & 29 \\
\hline $\begin{array}{c}\text { Fim de } \\
\text { semana }\end{array}$ & Casa & 72 & 23 h44min & 4 & 9 & 55 \\
\hline
\end{tabular}

Fonte: corpus de pesquisa

Já os dados gerados a partir do Diário do Uso do Tempo de Clarice durante a semana contaram com 120 atividades registradas, totalizando 21h29min, sendo que 109 atividades em $9 \mathrm{~h} 09 \mathrm{~min}$ ocorreram na creche e 11 atividades em $12 \mathrm{~h} 02 \mathrm{~min}$ no contexto familiar. No final de semana transcorreram 24 atividades em um período de $21 \mathrm{~h} 02 \mathrm{~min}$. 
No dia da semana, Clarice esteve nos seguintes locais: instituição de Educação Infantil, predominantemente na sala principal do Berçário I, mas também utilizou o corredor, auditório, sala da direção e hall da instituição. No período em que ficou com a família, as atividades ocorreram em casa (quarto, sala e banheiro) e no ônibus. No final de semana, as atividades realizaram-se em casa (quarto, sala, banheiro, cozinha, varanda, calçada) e parquinho que fica próximo à casa.

Clarice, enquanto esteve na creche, participou de encontros que envolveram 29 diferentes indivíduos, sendo 19 bebês, presentes no dia da geração dos dados, e 9 adultos: 2 professoras, 1 pesquisadora, 4 monitores, 1 funcionário de serviços gerais e 2 adultos da equipe da direção. No período da manhã, estiveram presentes a professora do turno da manhã, a pesquisadora e duas monitoras. No período da tarde, estiveram presentes a professora do turno da tarde, a mesma pesquisadora e as monitoras do período da tarde. No período da tarde também esteve presente uma das monitoras do período da manhã e o funcionário responsável pela limpeza da sala. Clarice participou de encontros pontuais também com outros adultos da equipe da direção, tanto no período da manhã quanto da tarde. Além disso, houve contato com crianças das outras turmas da instituição que não foram especificados no Diário. No contexto familiar, os encontros ocorreram com alguns membros da família, dentre eles: pai, mãe, irmão e tia. No final de semana, ela se relacionou com os mesmos membros da família, com exceção da tia.

No campo observação do Diário do dia da semana foram registradas 92 notas no período em que esteve na creche e 4 observações enquanto esteve com sua família. No final de semana foram registradas 3 observações. $O$ quadro 4 sintetiza as informações geradas nos Diários de Clarice:

Quadro 4 - Dados gerados nos Diários de Clarice

\begin{tabular}{|c|c|c|c|c|c|c|}
\hline \multicolumn{7}{|c|}{ Clarice } \\
\hline \multicolumn{2}{|c|}{} & Atividade & Duração & Local & $\begin{array}{c}\text { Com quem } \\
\text { estava }\end{array}$ & Observação \\
\hline $\begin{array}{c}\text { Dia da } \\
\text { Semana }\end{array}$ & Creche & 109 & $09: 09$ & 1 & 29 & 92 \\
\cline { 2 - 7 } & Casa & 11 & $12: 20$ & 1 & 4 & 4 \\
\hline $\begin{array}{c}\text { Fim de } \\
\text { semana }\end{array}$ & Casa & 24 & 21 h02min & 2 & 3 & 3 \\
\hline
\end{tabular}

Fonte: corpus de pesquisa 
Além dos Diários, as entrevistas realizadas com cada uma das mães compõem o corpus da pesquisa. A entrevista com Isadora, mãe do Augusto, foi realizada no dia 10 de fevereiro de 2014 e teve duração de 1h42min. A entrevista com Carolina, mãe de Clarice, foi realizada no dia 11 de fevereiro de 2014, e teve duração de 48 min.

\section{6 ÉTICA}

Antes de apresentarmos a análise dos dados faz-se necessário discutir sobre a ética na pesquisa com crianças. A ética na pesquisa relaciona-se às regras de conduta e aos princípios morais. As novas concepções de infância/criança nos instigam a discutir a dimensão ética desenvolvida nas pesquisas sobre essa temática. Ao passarmos a escutar o que as crianças têm a nos dizer, se faz necessário “[...] repensar a atuação do pesquisador tanto em seu caráter operatório-metodológico quanto ético" (CARVALHO; MÜLLER, 2010, p. 66).

Diversos autores vêm destacando a importância de as crianças estarem informadas sobre o que os pesquisadores estão fazendo desde o início da entrada em campo, bem como se desejam participar da pesquisa. Nos estudos com bebês esses aspectos tornamse complexos. Ferreira (2010) afirma que o debate em torno da noção da competência das crianças para entenderem a pesquisa e todas as suas implicações tende a agravar-se quanto menores elas forem, devido aos limites da sua linguagem verbal, da sua compreensão e da sua experiência social. Isso não significa que os recentes estudos realizados com bebês têm ignorado esse cuidado ético. Como afirma Corsaro, o consentimento da criança é uma etapa necessária, independentemente da idade. Assim, é preciso adotar estratégias adequadas, levando em consideração as características e capacidades das crianças (BARBOSA, 2014).

Outras questões são tratadas por Morrow (s.d.) em relação aos cuidados que devem ser tomados, como: as estratégias de pesquisa devem ser compatíveis e respeitarem os participantes; o local onde a pesquisa será desenvolvida é relevante, pois em alguns casos a participação da criança pode ter um caráter obrigatório; as crianças são competentes em suas ações, contudo os adultos são os responsáveis por garantir a segurança delas; é preciso levar em consideração as características do pesquisador - 
gênero, idade, cultura, origem - pois, estas podem enviesar seu olhar; os métodos utilizados devem priorizar a participação das crianças na geração dos dados.

O primeiro procedimento ético-metodológico adotado em nosso projeto de pesquisa foi a submissão deste ao Comitê de Ética em Pesquisa do Instituto de Ciências Humanas da Universidade de Brasília, responsável pela avaliação de pesquisas sociais. Após avaliação desse Comitê, o projeto foi aprovado ${ }^{15}$. A entrada em campo se deu após essa aprovação, além das devidas autorizações pela SEDF para a entrada na creche. A submissão do projeto ao Comitê teve a intenção também de avaliar se a pesquisa geraria algum tipo de constrangimento ou prejuízo a seus participantes. Vale lembrar que somente o parecer de um órgão não irá garantir automaticamente a segurança aos participantes e a ética na pesquisa, pois estas dependem principalmente da postura do pesquisador.

Nosso estudo, assim como em outras pesquisas com bebês, não possui a autorização expressa dos próprios bebês para participação da pesquisa, já que eles não podem nos informar verbalmente se aceitam participar dela. Isso exigiu um cuidado e sensibilidade maior na aproximação dos participantes da pesquisa. Estávamos atentos aos sinais e a outras linguagens dos bebês. Vale destacar que, apesar de contarmos com a participação de apenas dois bebês, esse cuidado não se restringiu apenas aos dois. Pois, a geração dos dados no dia da semana ocorreu no período em que eles estavam na creche, sendo assim, outros bebês estavam presentes. Nossa preocupação ética foi com a turma do Berçário I como um todo. Adotamos a postura de observar suas reações à nossa presença.

O contato com a instituição e com os pais foi facilitado pela pesquisadora responsável pelo projeto "Episódios Interativos de Bebês em Creche"16. Este já estava em andamento na turma do Berçário I quando iniciamos a presente pesquisa. Sendo assim, já havia um vínculo de confiança estabelecido pela coordenadora do referido projeto com os pais e profissionais responsáveis pela turma. A partir dessa relação foi possível a

\footnotetext{
${ }^{15} \mathrm{O}$ parecer de aprovação do Comitê de Ética em Pesquisa encontra-se no anexo A.

${ }^{16}$ Projeto coordenado pela Professora Dra. Fernanda Müller, o qual foi conduzido de 2011 a 2013, filiado ao Grupo Interdisciplinar de Pesquisa sobre a Infância (GIPI). O projeto investigou as possibilidades de interações de bebês, atendidos em uma creche pública do Distrito Federal. O projeto contou com a participação de alunos de graduação e mestrado da Universidade de Brasília.
} 
aproximação dos participantes da pesquisa. Após apresentar o projeto para alguns pais, perguntamos sobre a sua disponibilidade e observamos se eles se sentiam confortáveis em participar. Isso porque a pesquisa, por ter como instrumento o Diário do Uso do Tempo, iria expor não apenas a rotina do bebê na creche, mas também na família. 


\title{
4 TEMPO, OUVE BEM O QUE TE DIGO - ANÁLISE
}

\author{
Tempo tempo tempo tempo (...) \\ Entro num acordo contigo (...) \\ Ouve bem o que te digo (...) \\ (Caetano Veloso)
}

A epígrafe acima faz referência aos capítulos anteriores dessa dissertação, o que significa dizer que a construção da nossa análise parte do alinhavo do que foi discutido anteriormente e arrematado com os conceitos de Goffman. Neste capítulo apresentamos a estratégia analítica utilizada para o tratamento dos dados. O foco da análise voltou-se para as atividades que os bebês realizaram, e com quem os bebês estavam.

Realizamos dois movimentos para a organização e análise dos dados. O primeiro movimento foi a categorização a partir da análise das informações registradas nos Diários. Assim, pudemos elaborar o roteiro para as entrevistas com as mães. Nessa primeira organização buscamos realizar o que Luker (2008) apresenta como redução dos dados, a fim de que seja alcançada a sua essência. Segundo a autora, dessa forma pode-se manuseá-los e gerenciá-los de uma maneira melhor.

Os Diários do Uso do Tempo foram lidos de forma completa para avaliar quais as principais informações relatadas e como elas poderiam se relacionar a partir de categorias. Tais categorias basearam-se inicialmente no quadro de codificação de atividades do HETUS (EUROSTAT, 2004). A categorização foi realizada para dar objetividade aos dados, tentando encontrar um padrão, o que demandou a sua organização de acordo com as similaridades das suas características. Para estabelecer um padrão e não ficar com um número elevado de categorias, o que poderia inviabilizar a análise, foi convencionado o máximo de três categorias por atividade e, no mínimo, uma. Segue um exemplo (Quadro 5): 
Quadro 5 - Exemplo de categorias do Diário do Uso do Tempo de Augusto

\begin{tabular}{|c|c|c|c|c|c|c|c|c|}
\hline Atividade & $\begin{array}{l}\text { Hora } \\
\text { início }\end{array}$ & $\begin{array}{l}\text { Hora } \\
\text { fim }\end{array}$ & Local & $\begin{array}{l}\text { Com } \\
\text { quem } \\
\text { estava } \\
\end{array}$ & Observação & \multicolumn{3}{|c|}{ Categoria } \\
\hline $\begin{array}{l}\text { Brincando } \\
\text { com } \\
\text { Coelho }\end{array}$ & 08:17 & 08:20 & $\begin{array}{c}\text { Sala } \\
\text { principal }\end{array}$ & Bebê & $\begin{array}{l}\text { Manipula o } \quad \text { coelhinho } \\
\text { sozinho. Um menino } \\
\text { estava por perto. }\end{array}$ & Brincar & & \\
\hline $\begin{array}{l}\text { Engatinha } \\
\text { pelo } \\
\text { solário }\end{array}$ & 08:51 & 08:57 & Solário & $\begin{array}{l}\text { Grupo de } \\
\text { crianças }\end{array}$ & $\begin{array}{l}\text { Engatinha para solário } \\
\text { depois de a professora } \\
\text { abrir a porta para o } \\
\text { solário. Muitas crianças } \\
\text { saem ele acompanha e } \\
\text { fica circulando pelo } \\
\text { espaço. Encontra uma } \\
\text { folha de árvore no chão e } \\
\text { coloca na boca. } \\
\text { Professora interage com } \\
\text { ele para que tire da boca. } \\
\text { O grupo de crianças que } \\
\text { está próximo a ele se } \\
\text { desloca aos poucos. Ele } \\
\text { também engatinha um } \\
\text { pouco e para novamente. } \\
\text { Encontra um brinquedo e } \\
\text { fica manipulando com a } \\
\text { boca o objeto }\end{array}$ & Interação & exploração & deslocamento \\
\hline
\end{tabular}

Fonte: Corpus da pesquisa - Diário do dia da semana Augusto - registro realizado pela pesquisadora

Ao final desse exercício obtivemos 15 categorias relacionadas aos Diários dos bebês, sendo elas: alimentação, assistir televisão, brincar, colo, compras, deslocamento, dormir, exploração, expressão, família, filhos, higiene, interação, passeio, roupa. Após essa etapa, foram realizados alguns exercícios para verificar a duração, média e frequência de cada uma das categorias. Esse exercício foi realizado para cada um dos Diários dos bebês, tanto no dia da semana quanto no final de semana.

As categorias geradas a partir da primeira organização dos dados nos ajudaram a construir o roteiro para a entrevista, contudo, mostraram-se inviáveis para a análise devido ao grande número de categorias geradas e por serem internamente inconsistentes. O segundo movimento de organização dos dados consistiu em um novo exercício de síntese, com o objetivo de organizar as categorias a partir do cruzamento das informações registradas nos Diários das crianças e as informações apresentadas durante as entrevistas. Nesse momento, percebemos que as codificações propostas no modelo HETUS não contemplavam as especificidades das ações das crianças bem pequenas, o que demandou a criação da nossa própria categorização.

A princípio, definimos duas categorias: cuidados pessoais e interação. A categoria cuidados pessoais abarcava as atividades: sono, alimentação e higiene; e a categoria interação as atividades como: brincar, assistir à televisão, comunicação e outros. 
Entretanto, ao longo deste estudo, foi sendo construído um olhar atento sobre o conceito de interação. Inicialmente, nas primeiras organizações dos dados, os utilizamos como categorias distintas, seguindo o modelo de organização do HETUS. Todavia, ao separar essas duas dimensões, não conseguíamos dar continuidade às discussões, pois elas não se davam de forma separada no cotidiano dos bebês. A interação esteve presente em grande parte do tempo dos bebês, tanto na creche quanto na casa. Foi a partir das interações que pudemos caracterizar as situações de que os bebês participaram.

Devido ao destaque da categoria interação em nossos dados, foi necessário um mapeamento sobre os estudos realizados com bebês, os quais consideraram esse conceito. Tais estudos indicaram que o conceito de interação sofreu mudanças ao longo das últimas décadas, além de a abordarem sob uma nova perspectiva, isto é, a interação deixa de ser considerada somente entre mãe e bebê, e se estende para formas mais amplas de relacionamento. Anjos et al. (2004), Rossetti-Ferreira, Amorim e Oliveira (2009), Franchi e Vasconcelos et al. (2003), Carvalho et al. (2002), entre outros, realizaram um levantamento das produções acerca de interações de crianças pequenas e mostraram como o foco dos estudos mudou ao longo das últimas décadas, seja por mudanças conceituais ou por mudanças metodológicas.

De acordo com Anjos et al. (2004), os estudos na década de 1960 focavam principalmente as relações mãe-criança. Na década de 1970, emergiram questionamentos se as interações de pares contribuíam para o desenvolvimento de competências das crianças. Na década de 1980, alguns pesquisadores reconheceram que os bebês interagiam com pares. Na década de 1990, Carvalho, Império-Hamburger e Pedrosa (1997) definiram interação como mais do que o fazer algo juntos, pois a criança passa a contemplar também a regulação recíproca, implícita e não necessariamente intencional.

Nos anos 2000, observamos a continuidade dos esforços teóricos e metodológicos para o aperfeiçoamento do conceito. Rossetti-Ferreira, Amorim e Silva, (2000) propõem a perspectiva da Rede de Significações $(\operatorname{RedSig})^{17}$ para a coleta e a análise dos dados.

${ }^{17}$ Segundo os autores, “[...] essa perspectiva propõe o ser humano como um ser complexo, dotado de capacidades interativas, desde o nascimento, já que considera que o bebê nasce com um repertório biológico complexo, com um alto grau de organização perceptiva e expressiva, com uma capacidade de reconhecer e 
Franchi e Vasconcelos et.al. (2003) afirmam que o desajeitamento do bebê em seu primeiro ano de vida, ou a sua "incompletude motora", pode representar um elemento que favoreça a ocorrência das interações.

Percebe-se que há um reposicionamento das áreas do conhecimento em torno do conceito de interação, ainda que na prática persista concepções cunhadas durante a década de 1960 que enfatizavam principalmente as interações de mãe e criança, decorrentes da teoria do Apego de Bowlby. A temática passa a ser reconhecida como importante para a Educação Infantil, a exemplo da atenção que a inserção/adaptação das crianças, famílias e educadores passa a receber, além de compor um dos eixos norteadores para as práticas pedagógicas nas Diretrizes Curriculares Nacionais para Educação Infantil (2009).

Os estudos anteriormente citados ajudam a localizar e a respaldar o nosso corpus de pesquisa. Buscamos, na análise, contribuir para a ampliação das discussões acerca dessa temática e propomos como repertório teórico Erving Goffman, pois este autor desenvolveu sua obra em torno das situações do cotidiano relacionadas às interações.

Goffman foi um dos principais pensadores da vida social. Sua obra está baseada em como os pequenos gestos e rituais constituem as interações sociais. Segundo Manning (1992, p. 5, tradução nossa) "Um dos principais legados do trabalho de Goffman é que ele nos mostra como a fragilidade da vida do dia-a-dia é lentamente solidificada e ordenada por pequenos gestos e rituais". Assim, Goffman nos ajuda olhar para o cotidiano e "[...] ver a complexidade, a estabilidade e a importância da interação social aparentemente mundana" (MANNING, 1992, p. 4, tradução nossa).

Bourdieu (2004, p. 11), afirma que Goffman foi aquele:

[...] que fez com que a sociologia descobrisse o infinitamente pequeno: aquilo mesmo que os teóricos sem objeto e os observadores sem conceitos não sabiam perceber e que permanecia ignorado, porque muito evidente, como tudo o que é óbvio.

Nesse sentido, lançamos mão dos estudos desse autor, buscando cruzar a tênue linha entre o que nos parece ser óbvio nas atividades dos bebês e as possibilidades de 
análise do que eles fazem, em que condições e com quem. A obra do autor nos ajudou a entender as atividades cotidianas dos bebês, perceber os gestos e a comunicação, escapando do excesso de naturalidade com a qual essas atividades são usualmente vistas, além de contribuir para a compreensão da interação.

A obra de Goffman recorrentemente é associada ao Interacionismo Simbólico, que destaca a importância dos significados particulares apresentados pelos indivíduos na interação social, assim como os significados que ele obtém a partir dessa interação sob sua interpretação pessoal. Contudo, Goffman sempre recusou as classificações e os enquadramentos que a academia tentou dar a sua obra. Em uma resposta à Denzin e à Keller, que argumentaram que sua obra podia ser entendida como estruturalista e não interacionista, Goffman (1981) afirmou que compreendia a necessidade de se caracterizar as escolas de pensamento e os paradigmas, mas sentia-se triste com a tendência de fazer um trabalho a partir dessas necessidades (GOFFMAN, 1981).

No caso da presente pesquisa, Goffman nos ajuda a dar visibilidade às ações dos bebês, já que enfatiza situações que podem parecer pequenas e irrelevantes, ressaltando as interações. Goffman (2012b) afirma que vivemos em um mundo de encontros sociais e que em cada um desses encontros os indivíduos tendem a desempenhar um padrão de comportamento. Nesses encontros os indivíduos ao mesmo tempo que se expressam avaliam a sua atuação, bem como a de outros participantes envolvidos. Ou seja, na interação social há um processo de influência recíproca ou unilateral entre dois ou mais agentes sociais. Nas palavras do autor a interação pode ser definida:

[...] em linhas gerais, como a influência recíproca dos indivíduos sobre as ações uns dos outros, quando em presença física imediata. Uma interação pode ser definida como toda interação que ocorre em qualquer ocasião, quando, num conjunto de indivíduos, uns se encontram na presença imediata de outros (GOFFMAN, 2013, p. 27-28, grifo do autor).

Para Goffman, somos convocados a representar um papel em cada um dos encontros que de participamos, pois em cada uma dessas situações há um padrão de comportamento a ser seguido, ou seja, uma linha ${ }^{18}$. Nesse sentido, ao participar de diferentes encontros, adotamos uma fachada que, de acordo com Goffman (2013, p. 34),

\footnotetext{
${ }^{18}$ Neste trabalho sempre que nos referirmos a algum termo/conceito de Goffman escreveremos em itálico
} 
“[...] faz parte do desempenho do indivíduo que funciona regularmente de forma geral e fixa a fim de definir a situação para os que observam a representação". Em alguns casos, o indivíduo consegue manter a fachada correta nas diferentes situações, ou seja, age com o porte correto e os envolvidos na situação tratam-no com deferência. Mas há casos em que o indivíduo perde a fachada, executando algum comportamento não tolerado socialmente, ou não adequado para a situação.

Dessa forma, há um conjunto de regras ou normas morais para cada situação social em que os atores sociais estão envolvidos, elas vão moldar e regular como as pessoas se comportam. Ou seja, é uma espécie de palco social onde as pessoas, no momento em que entram nele, adaptam-se a situação e começam a agir no molde estabelecido. Mas isso não significa que Goffman postula a reprodução de comportamentos. Como afirma Manning (1992), as regras de interação não nos obrigam a desempenhar um determinado papel, mas são uma forma de exibir a ordem social:

[...] em vez de ver a previsibilidade da vida social como leis, Goffman pensou que a previsibilidade é algo que todos nós fazemos acontecer. Estas regras de interação não produzem a ordem social. Elas não nos obrigam a agir, mas elas são uma forma de exibir a ordem social [...] que estão sujeitas a interpretação, a discordância (MANNING, 1992, p. 10, tradução nossa).

Assim, vale dizer que, ao postular os comportamentos esperados em cada situação social, Goffman não está afirmando que há apenas uma reprodução das ações, mas sim uma construção coletiva diária de tais comportamentos. Dito isso, podemos passar a explorar quais os conceitos da obra do autor nos ajudam a analisar os dados do presente estudo.

Goffman nos permitiu compreender cada atividade, bem como definir o ponto central de cada situação descrita no Diário do Uso do Tempo. Ao categorizar os dados, tentamos explorar a atividade em que o bebê estava envolvido, para isso utilizamos alguns esquemas fundamentais de compreensão que estão disponíveis em nossa sociedade. De acordo com Goffman (2012a), os indivíduos quando envolvidos em uma situação tendem a usar os esquemas de interpretação, que estão disponíveis em nossa sociedade, permitindo assim os indivíduos reconhecerem o acontecimento e escolherem qual comportamento a ser adotado.

Para além da compreensão do significado de cada situação também atentamos ao fato de que um primeiro recorte de informação já tinha sido realizado tanto pela 
pesquisadora quanto pelas mães que preencheram os Diários. Goffman (2012a) assume que, dentro de uma cena, os indivíduos reconhecem o objetivo principal para onde a atenção é focada, o que pode ser definido como atividade primária. Além disso, consideramos também que, ao ser preenchido o campo "Atividade" do Diário do Uso do Tempo, estávamos tentando responder a uma das perguntas principais da obra de Goffman, qual seja: "O que está acontecendo aqui?" (GOFFMAN, 2012a, p. 31). Conforme o próprio autor, essa pergunta é bastante aberta, já que:

Qualquer acontecimento pode ser descrito em termos de um enfoque que inclui um espectro amplo ou um espectro estreito e - como questão relacionada, mas não idêntica - em termos de um enfoque em primeiro plano ou distante. E que ninguém tem uma teoria sobre qual a abertura e qual o nível que serão efetivamente empregados. Para começar, deve ser-me permitido o direito de escolher arbitrariamente minha abertura e meu nível, sem justificação especial (GOFFMAN, 2012a, p.31).

Assim, consideramos que cada uma das mães e a pesquisadora escolheram qual recorte fazer da cena, ainda que estivessem orientadas a fazer uma descrição mais detalhada possível acerca das ações dos bebês. Entretanto, cada sujeito se valeu de uma lente para olhar a cena. Pois, como afirma Nunes (1993, p. 40), “[...] toda a produção da informação é uma forma de processar experiências, susceptíveis de serem reenquadradas".

Os dados das experiências dos bebês foram analisados por meio de quadros, termo que Goffman toma emprestado de Bateson. Goffman (2012a) define quadro como o conjunto de princípios de organização que governam os acontecimentos sociais e o nosso envolvimento subjetivo neles. Nas palavras do autor:

\footnotetext{
Pressuponho que as definições de uma situação são elaboradas de acordo com os princípios de organização que governam os acontecimentos - pelo menos os sociais - e nosso envolvimento subjetivo neles; quadro é a palavra que uso para me referir a esses elementos básicos que sou capaz de identificar. Esta é a minha definição de quadro. Minha expressão "análise de quadros" é um slogan para referir-se ao exame, nesses termos, da organização da experiência (GOFFMAN, 2012a, p. 34, grifo do autor).
}

Como afirmam Mendonça e Simões (2012, p. 189, grifo dos autores): "São esses princípios conformadores dos quadros que permitem a definição da situação pelos sujeitos". Assim, devemos buscar compreender dentro da situação que os bebês se inserem qual o quadro que os envolve e "[...] qual o posicionamento que se deve adotar perante ele" (MENDONÇA; SIMÕES, 2012, p. 189). 
O termo situação é importante para a obra de Goffman (2010, p. 28), que assim o define:

[...] ambiente espacial completo em que ao adentrar uma pessoa se torna um membro do ajuntamento que está presente, ou que então se constitui. As situações começam quando o monitoramento mútuo ocorre, e prescrevem quando a penúltima pessoa sai.

Em nossos dados notamos que os bebês estão predominantemente acompanhados ou são observados, seja porque estão na creche e estão envolvidos em um ambiente com outras crianças e adultos, ou porque, em casa, sempre contam com a companhia de um adulto. Contudo, em nossos dados notamos que a copresença do bebê com o adulto ou com outra criança não necessariamente tinham significação para a situação em que os bebês estavam envolvidos. Assim, é importante distinguir as interações desfocadas e focadas.

Para Goffman (2010, p. 34) a interação desfocada diz a respeito à “[...] comunicação que ocorre quando se recolhe informações sobre outra pessoa ao se olhar de relance para ela [...] trata em grande parte do gerenciamento da simples e mera copresença". Neste caso, há a consciência da presença do outro, mas não há uma interação direta. Geralmente, a comunicação utilizada é a não verbal, isso inclui a aparência corporal e os atos pessoais: vestuário, postura, movimento e posição no espaço, expressões faciais, volume do tom de voz e gestos Já a interação focada “[...] ocorre quando as pessoas se juntam e cooperam abertamente para manter um único foco de atenção" (GOFFMAN, 2010, p. 35), normalmente revezando a fala ou simplesmente uma atenção mútua e recíproca. Em nossa pesquisa tratamos das interações focadas principalmente, mas também consideramos as interações desfocadas para caracterização da situação vivenciada pelos bebês, as informações das interações desfocadas nos deram dados de contexto.

As atividades dos bebês podem ser enquadradas em mais de um quadro o que Goffman chama de quadro dentro do quadro. Nossa opção foi trabalhar com as interpretações que os adultos deram a essas ações, pois, ao registrar a informação no Diário do Uso do Tempo, realizaram o enquadramento segundo o que consideram ser o objetivo da ação, o que seria a atividade primária. Para tentar abarcar mais profundamente o que os bebês estavam fazendo em cada situação, trabalhamos em nossa análise com 
mais um conceito de Goffman, qual seja: tom. Assim, destacamos dentro de cada situação qual o tom da atividade.

Goffman (2012a) define tom como sendo uma atividade primária transformada, em que uma nova camada de significados é adicionada sobre uma faixa de atividade preconcebida. Ou seja, reposiciona-se “[...] um acontecimento a partir de outro ângulo de percepção" (HANGAI, 2012, p. 2). Nos termos de Goffman (2012a, p. 71):

[...] tom [key]. Refiro-me aqui ao conjunto de convenções pelas quais uma dada atividade, já significativa em termos de algum esquema primário, é transformada em algo pautado sobre esta atividade, mas visto pelos participantes como algo muito diferente.

Por exemplo, uma briga pode ser enquadrada como um esquema primário, mas se este conflito for, na verdade, um faz de conta, uma brincadeira, então se adiciona ao esquema primário da luta um novo significado, que permite o reconhecimento da situação como uma brincadeira.

Definido os conceitos de Goffman, passamos à análise dos dados propriamente dita. Destacaremos as atividades: sono, alimentação e higiene, sintetizadas na categoria cuidados e a brincadeira, que ocorreram tanto no espaço da creche quanto da casa. Utilizaremos para cada situação social alguns dos conceitos de Goffman apresentados nesta seção.

\subsection{CUIDAdOS NA CRECHE E NA FAMíLIA}

Vamos tratar nesta subseção da categoria cuidados, recorrente nos Diários de ambas as crianças. Ela está presente nos dois contextos sociais em que os bebês preponderantemente participam - creche e família - e representa o maior uso do tempo dos bebês. Dentro da categoria cuidados estão as situações sociais relacionadas ao sono, alimentação e higiene (Quadros 6 e 7).

Vale destacar que a discussão sobre os cuidados é uma temática recorrente nos estudos sobre a infância, mais especificamente nos estudos sobre/com crianças em contextos educativos. No geral, os estudos Coutinho (2002), Kramer (2003), Montenegro (2005), Kuhlmann Jr (2010), Guimarães (2011), dentre outros discutem a dicotomia entre 
o cuidar e o educar estabelecida nas instituições de Educação Infantil, assim como as implicações dessa separação para o trabalho pedagógico desenvolvido com as crianças.

Segundo Kuhlmann Jr. (2010), as primeiras creches populares no Brasil foram criadas para atender a mãe trabalhadora, sendo marcadas pela função de guarda e assistência. Essa instituição, influenciada pelo discurso higienista e da puericultura, focava suas ações no cuidado, este entendido como forma de atender às necessidades relacionadas ao sono, higiene e alimentação, além de proteção.

Contudo, autores como Guimarães (2011) propõem a superação dessa visão de cuidado. Para ela, o cuidar não se restringe a ações instrumentais do adulto para com a criança, mas dizem respeito à criação de práticas do adulto para com ele mesmo, que produzem uma atmosfera de atenção, escuta e disponibilidade na creche como um todo. Guimarães (2011) utiliza Foucault para ampliar a noção do cuidar que, segundo ela, é entendido como uma postura ética, "[...] não só da ação dos adultos sobre as crianças, como também a promoção de uma cultura de si, atenção ao outro, prática de liberdade" (GUIMARÃES, 2011, p. 41).

Não ignoramos o fato apresentado nas pesquisas recentes acerca da problematização dos cuidados serem entendidos apenas como sono, higiene e alimentação. Contudo, esses estão imbricados nos tempos institucionais e fazem parte da rotina da instituição onde o estudo foi conduzido. Outro fator é que essa categoria pedagógica já foi bem explorada no contexto da Educação Infantil, mas não temos muitos estudos que abordem essa rotina no espaço familiar. Portanto, destacamos esta categoria em nosso estudo buscando compreender como ela se dá na creche e na casa.

A maior parte do tempo para ambas as crianças foi empregado para o sono, seguido da alimentação e depois higiene. 
Quadro 6 - Total de horas do dia da semana por subcategoria

\begin{tabular}{|c|c|c|c|}
\hline \multicolumn{4}{|c|}{ Augusto } \\
\hline & & Duração & Quadros \\
\hline \multirow{3}{*}{ Creche } & Sono & $01: 17$ & 2 \\
\cline { 2 - 4 } & Alimentação & $00: 21$ & 4 \\
\cline { 2 - 4 } & Higiene & $00: 26$ & 3 \\
\hline \multirow{3}{*}{ Casa } & Sono & $08: 53$ & 2 \\
\cline { 2 - 4 } & Alimentação & $01: 13$ & 10 \\
\cline { 2 - 4 } & Higiene & $00: 48$ & 7 \\
\hline
\end{tabular}

\begin{tabular}{|c|c|c|c|}
\hline \multicolumn{4}{|c|}{ Clarice } \\
\hline & & Duração & Quadros \\
\hline \multirow{3}{*}{ Creche } & Sono & $01: 31$ & 1 \\
\cline { 2 - 4 } & Alimentação & $01: 02$ & 6 \\
\cline { 2 - 4 } & Higiene & $00: 16$ & 2 \\
\hline \multirow{3}{*}{ Casa } & Sono & $08: 20$ & 2 \\
\cline { 2 - 4 } & Alimentação & $00: 55$ & 3 \\
\cline { 2 - 4 } & Higiene & $00: 25$ & 2 \\
\hline
\end{tabular}

Fonte: corpus de pesquisa

Quadro 7 - Total de horas do final de semana por subcategoria

\begin{tabular}{|c|c|c|}
\hline \multicolumn{3}{|c|}{ Augusto } \\
\hline & Duração & Quadros \\
\hline Sono & $09: 36$ & 4 \\
\hline Alimentação & $02: 39$ & 16 \\
\hline Higiene & $00: 40$ & 9 \\
\hline
\end{tabular}

\begin{tabular}{|c|c|c|}
\hline \multicolumn{3}{|c|}{ Clarice } \\
\hline & Duração & Quadros \\
\hline Sono & $10: 22$ & 3 \\
\hline Alimentação & $03: 15$ & 8 \\
\hline Higiene & $00: 25$ & 2 \\
\hline
\end{tabular}

Fonte: corpus de pesquisa

Apresentaremos a seguir como essas atividades ocorreram no dia da semana e final de semana para cada criança e, na sequência, discutiremos esses dados considerando conceitos de Goffman.

\subsubsection{SONO}

Iniciamos nossa análise pela atividade que representa um dos maiores usos do tempo dos bebês: o sono. Os dados apresentados nos Diários do Uso do Tempo mostram que Augusto dormiu 1h17min das 8h19min que passou na creche e das 14h32min que esteve em casa, dormiu 8 h53min. Ou seja, dentro das 22h51min registradas no Diário do dia da semana, 10h10min referem-se ao descanso do bebê. Em relação ao final de semana, das 23h44min registradas no Diário do Uso do Tempo, 09h36min foram utilizadas para o sono.

No dia da semana Augusto estava febril. No período em que permaneceu na creche, ele dormiu em dois momentos diferentes do restante da turma. O momento de dormir, segundo a rotina da creche, é após o horário do almoço. Contudo, nesse dia, ele 
dormiu antes do horário do almoço e à tarde, no período em que seus colegas estavam acordando.

Os dois momentos de sono na creche ocorreram fora do espaço convencionado. Ele dormiu na sala de atividades em um bebê conforto, o que ocasionou alguns momentos de interferência no seu sono, a exemplo do que ocorreu no período da manhã. O primeiro momento aconteceu quando um bebê da turma retirou a sua chupeta. Augusto começou a chorar, o bebê então devolveu sua chupeta; Augusto voltou a dormir. Outro momento ocorreu quando Augusto foi movimentado do bebê conforto para um carrinho de bebê; nesse momento ele acordou e não voltou a dormir, conforme observamos no Quadro 8.

Quadro 8 - Interferência no sono de Augusto

\begin{tabular}{|c|c|c|c|c|c|}
\hline Atividade & $\begin{array}{c}\text { Hora } \\
\text { início }\end{array}$ & $\begin{array}{c}\text { Hora } \\
\text { fim }\end{array}$ & Local & $\begin{array}{c}\text { Com quem } \\
\text { estava }\end{array}$ & \multicolumn{1}{|c|}{ Observação } \\
\hline Dormiu & $09: 47$ & $10: 25$ & $\begin{array}{c}\text { Sala } \\
\text { principal }\end{array}$ & $\begin{array}{c}\text { Ivan, e depois } \\
\text { sozinho }\end{array}$ & $\begin{array}{l}\text { Ivan tirou a chupeta de Augusto e } \\
\text { ele acordou, mas logo voltou a } \\
\text { dormir (Ivan devolveu a chupeta). }\end{array}$ \\
\hline $\begin{array}{c}\text { Teresa pega- } \\
\text { o no colo }\end{array}$ & $10: 25$ & $10: 25$ & $\begin{array}{c}\text { Sala } \\
\text { principal }\end{array}$ & $\begin{array}{c}\text { Teresa (vice- } \\
\text { diretora) }\end{array}$ & $\begin{array}{l}\text { Teresa retirou Augusto da } \\
\text { cadeirinha para colocar no carrinho } \\
\text { para poder colocar outra criança } \\
\text { que estava com sono), só que, no } \\
\text { meio dessa movimentação, ele } \\
\text { acordou e não voltou a dormir. }\end{array}$ \\
\hline
\end{tabular}

Fonte: Corpus da pesquisa - Diário do dia da semana de Augusto - registro realizado pela pesquisadora

No período em que Augusto esteve em casa, ele dormiu às 22h09min e acordou em diversos momentos para mamar. De acordo com a mãe, ele sempre acordava para mamar; no dia registrado durante a semana, ele acordou seis vezes, por esse motivo, a mãe acabou colocando-o para dormir no quarto dos pais.

MÃE: É. A mamadeira, ele [...] tomava mais na hora de dormir e na hora que acordava. Mais durante a noite, porque ele inda acorda um pouquinho à noite, né. [...] todo santo dia, ele acorda à noite e às vezes bebe um pouquinho assim. Às vezes dou água para ele, nem dou leite mesmo porque mais eu vejo que é sede. Chupa lá um pouquinho, dorme de novo [...] (Entrevista com Isadora, mãe de Augusto, 10/02/2014, linhas 66-70).

MÃE: Ele divide com a irmã o quartinho. Só que ele é assim: ele dorme no berço, mas tem vezes que eu tiro. Tem horas que eu não aguento não, porque ele é assim, ele tem muito essa mania de acordar, ele dá uma choramingadinha, toma o leite e dorme. É até um costume que eu estou tentando aos poucos tirar, né. Mas ele, nessa época ele não sabia ainda, ele não conseguia pegar a chupeta e pôr na boca. Hoje em dia ele já faz isso. Então, quando ele acorda, ele mesmo caça assim, dá uma resmungada, pega a chupeta, põe na boca e volta a dormir. 
Nessa época não. Se ele acordasse ele só voltava a dormir com a chupeta. Aí eu tinha que levantar, ir lá ao quarto e pegar. Então tinha vezes que eu acordava cinco vezes à noite ou seis. Aí eu falava “ah, quer saber, não estou nem aí não, dorme aqui logo que pelo menos eu descanso" (risos). Então assim, ele dormia algumas vezes no quarto, algumas vezes com a gente. (Entrevista com Isadora, mãe de Augusto, 10/02/2014, linhas 146-160).

Ainda em relação ao registro do sono que ocorreu durante a semana, notamos que esse momento em que o bebê está dormindo os pais aproveitam para cuidar dele. Observamos no registro (Quadro 9) que o pai aproveitou para cortar as unhas do bebê enquanto ele dormia.

Quadro 9 - Outras atividades enquanto o bebê dormia

\begin{tabular}{|c|c|c|c|c|c|}
\hline Atividade & $\begin{array}{c}\text { Hora } \\
\text { início }\end{array}$ & $\begin{array}{c}\text { Hora } \\
\text { fim }\end{array}$ & Local & $\begin{array}{c}\text { Com quem } \\
\text { estava }\end{array}$ & Observação \\
\hline $\begin{array}{c}\text { Cortar } \\
\text { unhas }\end{array}$ & $22: 15$ & $22: 20$ & Sala & Pais e irmã & $\begin{array}{c}\text { O pai cortou as unhas do Augusto enquanto ele } \\
\text { mamava já adormecido }\end{array}$ \\
\hline
\end{tabular}

No final de semana o sono de Augusto foi caracterizado por momentos em que acordou durante a noite (3 vezes) devido a algum barulho, ou para mamar, como também por momentos de sono no carro (1h10min) e também por sono durante a tarde $(57 \mathrm{~min})$.

Já Clarice dormiu 1h31min das 9h09min do período em que esteve na creche e das $14 \mathrm{~h} 30 \mathrm{~min}$ que passou com a família, dormiu $8 \mathrm{~h} 20 \mathrm{~min}$. Ou seja, dentro das $23 \mathrm{~h} 39 \mathrm{~min}$ registradas no Diário do Uso do Tempo do dia da semana, 9h51 min foram dormindo. Em relação ao final de semana Clarice dormiu 10h22min das 21h02min registradas.

No registro da creche de Clarice, ela dormiu no momento estipulado pela rotina da instituição com alguma dificuldade, pois estava sem sua chupeta (Quadro 10). A mãe não levou a sua chupeta para a creche, pois Clarice estava com um machucado na boca e o pediatra recomendou que não fosse utilizada. Ela passou cerca de 30min negociando com a professora para conseguir a chupeta. A professora acabou arrumando uma chupeta que parecia com a dela, o que a fez dormir. 
Quadro 10 - Negociação no momento do sono de Clarice

\begin{tabular}{|c|c|c|c|c|c|}
\hline Atividade & $\begin{array}{l}\text { Hora } \\
\text { início } \\
\end{array}$ & $\begin{array}{l}\text { Hora } \\
\text { fim }\end{array}$ & Local & \begin{tabular}{|c|}
$\begin{array}{c}\text { Com quem } \\
\text { estava }\end{array}$ \\
\end{tabular} & Observação \\
\hline $\begin{array}{c}\text { Entra na } \\
\text { sala de } \\
\text { berços atrás } \\
\text { da } \\
\text { professora }\end{array}$ & $11: 13$ & $11: 31$ & $\begin{array}{c}\text { Sala de } \\
\text { berços }\end{array}$ & $\begin{array}{c}\text { Professora, } \\
\text { Isadora }\end{array}$ & $\begin{array}{l}\text { Professora coloca-a em um berço, ela fica } \\
\text { deitada, mas depois de um tempo levanta. } \\
\text { Ela gesticula algo para professora. Pede a } \\
\text { pepe. Professora conversa com ela contando } \\
\text { que a mãe tirou a sua chupeta. Professora a } \\
\text { nina. }\end{array}$ \\
\hline $\begin{array}{l}\text { Permanece } \\
\text { acordada }\end{array}$ & $11: 31$ & $11: 41$ & $\begin{array}{l}\text { Sala de } \\
\text { berços }\end{array}$ & Professora & $\begin{array}{l}\text { Professora conversa com Clarice, pergunta } \\
\text { se ela arrumar uma pepe ela irá dormir. } \\
\text { Clarice faz um gesto afirmativo com a } \\
\text { cabeça. Professora sai da sala para arrumar } \\
\text { uma chupeta. A professora entrega para ela } \\
\text { uma chupeta, mas Clarice reconhece que } \\
\text { não é a sua e recusa. Professora sai } \\
\text { novamente da sala. Clarice fica em pé no } \\
\text { berço observando. Olha para a professora } \\
\text { vindo em sua direção e sorri, quando a } \\
\text { professora tenta colocar a chupeta em sua } \\
\text { boca mais uma vez reconhece que não é a } \\
\text { sua e se recusa novamente. Professora sai à } \\
\text { procura de um cordão porque Clarice usava } \\
\text { uma chupeta com cordão vermelho. } \\
\text { Professora consegue um cordão e entrega a } \\
\text { chupeta para ela, Clarice aceita [...] }\end{array}$ \\
\hline
\end{tabular}

Fonte: Diário dia da semana Clarice - Creche - registro realizado pela pesquisadora

No registro do dia da semana realizado pela mãe, ela informou que Clarice dormiu dentro do ônibus na volta da creche para casa e, em casa, foi dormir às $22 \mathrm{~h} 30 \mathrm{~min}$. A mãe relatou, na entrevista, que a criança sempre dorme quando está dentro do ônibus e que o trajeto de casa até a creche demora cerca de 40min.

PESQUISADORA. É... no diário você relatou que você foi para casa, um dia você foi de ônibus outro dia você foi de carro, normalmente quando você vai de ônibus a Clarice faz o que quando você está dentro do ônibus?

MÃE. Ela dorme.

PESQUISADORA. Tanto na ida quando na volta?

MÃE. É, isso. Assim que a gente entra dentro do ônibus, ela senta no meu colo e já dorme, daqui até chegar em casa (Entrevista com Carolina, mãe de Clarice, 11/02/2014, linhas 205-211).

Já os momentos de sono de Clarice durante o final de semana foram caracterizados por um descanso no começo da tarde, após o almoço, que durou 2h10min e, a noite, ela foi dormir às $21 \mathrm{~h} 30 \mathrm{~min}$ e dormiu por $8 \mathrm{~h} 30 \mathrm{~min}$, acordando em um momento da noite para mamar. 
Para a situação social caracterizada pelo sono, observamos que os dois bebês usaram mais ou menos a mesma quantidade de tempo quando estavam na creche, com a diferença de que Augusto dormiu em dois momentos, enquanto Clarice dormiu em apenas um. Já com relação ao sono em casa à similaridade se mantem no dia da semana, mas há uma diferença de aproximadamente 50min no final de semana. Ambos os bebês costumam dormir durante os deslocamentos feitos em veículos automotivos. Na subseção "Contrastando as situações sociais relacionadas aos cuidados" trataremos de outros aspectos dessa situação social que também foram comuns para a alimentação e higiene.

\subsubsection{ALIMENTAÇÃO}

A alimentação de Augusto no dia de semana (Quadro 6) é caracterizada pelo registro de 14 momentos com duração total de $1 \mathrm{~h} 34 \mathrm{~min}$, sendo que 4 destes com duração de 21 min ocorreram na creche e 10 com duração de 1 h13min transcorreram na casa. $\mathrm{Na}$ creche, esses momentos foram café da manhã às 8h12min com duração de 4 min; almoço às 10h52min com duração de $7 \mathrm{~min}$; lanche da tarde às 13h26min com duração de 6 min; jantar às15h33min com duração de $4 \mathrm{~min}$.

Apesar de a instituição de Educação Infantil chamar a última refeição de jantar, observamos nos Diários que ambas as crianças se alimentam quando chegam em casa. Augusto toma vitamina (17h50min), mama (18h52min) e janta com a família (21h40min). Depois disso, ainda mama mais 7 vezes no decorrer da noite até o momento de ir para a creche novamente.

A mãe de Augusto, na entrevista, trata dos hábitos alimentares do filho, principalmente relacionados ao mamar.

MÃE: Ah, é um problema, porque ele come. Por ele, ele come o dia inteiro (risos). Ele é muito comilão, ele é ótimo para comer. Então assim, nessa época do relatório... Porque de lá para cá ele já mudou os hábitos, não mama mais... Então assim, mamar geralmente era toda vez que eu percebia que ele estava meio enjoadinho, ele mesmo vinha, quando ele estava um pouquinho com fome ele mesmo vinha, pedia para mamar. E muitas vezes quando ele estava enjoadinho, tipo às vezes dava aquelas crises de neném que de birrinha, é só dar de mamar que ele parava né. Em geral, ele comia assim de duas em duas horas comia alguma coisinha. Mamar não tinha muita regra não. Mas ele mamava mais, às vezes menos, porque nessa fase eu já não tinha muito leite. O mamar, eu acho que era mais aquela coisa mesmo do contato, do costume dele, né. Mas não era alimentação não, era só para enganar mesmo, ele tinha 
que comer outras coisas, mas... (Entrevista com Isadora, mãe de Augusto, 10/02/2014, linhas 49-58).

MÃE: É. A mamadeira, ele... Nessa época também até hoje, ele tomava mais na hora de dormir e na hora que acordava. Mais durante a noite, porque ele ainda acorda um pouquinho à noite, né. E geralmente até hoje ele toma antes de dormir uma mamadeirinha, às vezes à noite... Às vezes não, todo santo dia, ele acorda à noite e às vezes bebe um pouquinho assim. Às vezes dou água para ele, nem dou leite mesmo porque mais eu vejo que é sede. Chupa lá um pouquinho, dorme de novo. Durante o dia a gente não costumava dar muita mamadeira para ele não. (Entrevista com Isadora, mãe de Augusto, 10/02/2014, linhas 66-71).

Já em relação ao final de semana, consta no Diário de Augusto 16 momentos de alimentação, com duração total de 2h39min (Quadro 7). A mãe inicia o registro no Diário do final de semana pelo período da noite, momento em que o bebê já estava dormindo. Ela registra que o bebê acordou 4 vezes durante a noite para mamar. Comeu biscoito que pegou sozinho no armário de casa às 9h29min e novamente às 09 h52min. Ele lanchou às $12 \mathrm{~h} 35 \mathrm{~min}$ e às $14 \mathrm{~h} 35 \mathrm{~min}$ almoçou em um restaurante, seguindo o horário da agenda da família. Antes do jantar ele tomou sorvete com a família (16h20min), mamou duas vezes (17h45min e 18h50min), comeu "danoninho" (às 19h25min) e jantou com a família (22h45min). Ainda comeu brigadeiro (23h45min) e tomou mamadeira (00h27 min).

Percebemos que o bebê não se alimenta nos mesmos horários durante a semana e final de semana. As ocasiões sociais de que ele participa são diferentes e cada uma delas tem uma configuração própria. Na creche as crianças não têm acesso aos alimentos a não ser por meio da oferta dos adultos, enquanto em casa alguns alimentos ficam ao alcance do bebê. Os tempos da creche são mais rígidos, enquanto da casa são mais flexíveis ou estão mais abertos ao imprevisto. A mãe informa que as famílias são orientadas para seguirem os mesmos horários da rotina da creche, mas ela não consegue seguir esses horários e também acredita que, no final de semana, a rotina deva ser mais livre.

MÃE: Não, eles orientam né, que no fim de semana tem uma rotina, mas eu
não consigo manter, né. Por exemplo, acho que na creche eles almoçam 11
horas. Não dou conta de fazer almoço para eles 11 horas da manhã,, né (risos).
Então, dormir fim de semana, todo dia por exemplo, a Dudinha (irmã) tem um
horário certinho, agora eu não sei bem como está, mas dormia todo dia de meio
dia às duas. Em casa aquela hora que ela ainda estava indo almoçar, estamos
na rua, está na casa de primo... Então assim, eu deixava à vontade, vamos
comer na hora certa aqui mais ou menos, vamos dar uma comidinha, né. Meio
dia ou meio dia e trinta assim, almoça, mas eu não ficava assim em cima [...]
(Entrevista com Isadora, mãe de Augusto, 10/02/2014, linhas 814-824).

Os momentos de alimentação registrados no Diário de Clarice no dia da semana totalizam 9 em 1h57min, sendo que ocorreram 6 momentos com duração total de $1 \mathrm{~h} 02$ 
min no período em que ela esteve na creche e 3 que totalizaram 55 min no período em que esteve com a família.

Clarice na data da primeira geração dos dados já comia sozinha. Ela, assim como Augusto, iniciou sua alimentação na creche pelo café da manhã às 8h16min com duração de 14min. Às 9h04min pegou um biscoito oferecido pela professora, mas não o comeu. Ela ficou com o biscoito na mão, circulando pela sala, colocando-o algumas vezes na boca. Essa situação durou 5 min e foi finalizada quando perdeu o biscoito no meio da sala. Às 9h16min ganhou outro biscoito, após ficar gesticulando para a professora, e novamente não comeu.

Clarice começou almoçar às 10h49min e esta atividade teve duração de 10min. Tomou o lanche da tarde às $13 \mathrm{~h} 32 \mathrm{~min}$, gastando também $10 \mathrm{~min}$ nessa atividade. Ainda na escola ela comeu biscoito às $17 \mathrm{~h} 13 \mathrm{~min}$. Voltou a comer em casa, às $21 \mathrm{~h} 30 \mathrm{~min}$ (duração 20min), contudo, apesar de não estar registrado no Diário, a mãe afirmou na entrevista, que sempre dá um lanche para ela após saírem da instituição. E por fím Clarice tomou mamadeira quando acordou às 6h10min, antes de sair novamente para creche.

Já em relação ao final de semana, há o registro de 8 momentos com duração de 3h15min. Clarice tomou mamadeira quando acordou, 7h15min; e gastou aproximadamente $15 \mathrm{~min}$ nessa atividade. O café da manhã foi servido às $09 \mathrm{~h} 40 \mathrm{~min}$ e ela comeu com a mãe e o irmão, gastando 35min nessa atividade. Às $11 \mathrm{~h} 45 \mathrm{~min}$ comeu um lanche, gastando $15 \mathrm{~min}$ e almoçou às $13 \mathrm{~h}$ com o irmão (duração de $30 \mathrm{~min}$ ). Às $16 \mathrm{~h}$ comeu outro lanche, com duração de $30 \mathrm{~min}$, e depois jantou às 20h10min, gastando $25 \mathrm{~min}$. Tomou mamadeira uma vez à noite e depois de manhã.

Carolina, mãe de Clarice, informou na entrevista que tentava manter uma rotina em relação aos horários de alimentação:

MÃE. Quando a gente tá em casa eu sempre mantenho um horário das alimentações, mas quando a gente sai para passear, que às vezes falta alguma coisa, aí é flexível, é quando eu posso. [...] aí é... tem que quando ela dorme também na rua, é essas coisas, mas em casa é sempre o mesmo horário, que aí ela tem horário para acordar, tomar café, dormir, essas coisas.

PESQUISADORA. E aí, você sente que aquela coisa assim que às vezes as pessoas falam 'ah tem aquele reloginho', naquela hora começa a pedir para comer? 
MÃE. É desse jeito, quando ela desperta ela já pede logo, ela não espera não, enquanto não dá ela não sossega (Entrevista com Carolina, mãe de Clarice, 11/02/2014, linhas 30-38).

Observamos que as duas mães têm posicionamentos diferentes acerca dos horários para alimentação: uma procura seguir os horários da creche e a outra adota horários flexíveis. No geral, para ambos os bebês houve diferença entre os horários da casa e da creche. Em casa, existiu um espaço maior para o imprevisto e para o não planejado. No espaço da creche, em geral, seguiu-se uma rotina segundo o tempo que os adultos definiram.

As duas crianças, quando estavam no espaço da creche, usaram uma quantidade diferente de tempo. Augusto gastou 21min com alimentação, enquanto Clarice 1h02min. Alguns dados de caracterização dos quadros precisam ser considerados, tais como a condição fisiológica de cada criança. Augusto, no dia do preenchimento do Diário, estava doente, o que, segundo a mãe e a professora, acabou afetando o seu apetite. Outro fator a ser considerado está relacionado à autonomia de cada criança ao se alimentar. Clarice já comia com autonomia, enquanto Augusto dependia de um adulto para essa atividade. A autonomia de Clarice em comer sozinha fazia com que o tempo dela fosse mais livre e as negociações com os adultos mais presentes, como pode ser observado no Quadro 11 registrado no Diário de Clarice pela pesquisadora.

Quadro 11 - Negociação no momento da alimentação de Clarice

\begin{tabular}{|c|c|c|c|c|c|}
\hline Atividade & $\begin{array}{l}\text { Hora } \\
\text { início }\end{array}$ & Hora fim & Local & $\begin{array}{l}\text { Com } \\
\text { quem } \\
\text { estava }\end{array}$ & Observação \\
\hline $\begin{array}{c}\text { Monitora } \\
\text { coloca-a no } \\
\text { cadeirão }\end{array}$ & $15: 22$ & $15: 34$ & $\begin{array}{c}\text { Sala } \\
\text { principal }\end{array}$ & $\begin{array}{c}\text { Monitora } \\
\mathrm{e} \\
\text { professora }\end{array}$ & $\begin{array}{l}\text { Ela resmunga, a monitora tira ela do cadeirão, } \\
\text { Clarice continua a resmungar e vai para longe. } \\
\text { Volta e fica atrás do cadeirão. A monitora coloca } \\
\text { outras crianças sentadas. Depois de um tempo a } \\
\text { monitora chama-a. Ela gesticula e resmunga. A } \\
\text { monitora coloca ela no cadeirão, ela aceita. Recebe } \\
\text { seu jantar (comida pastosa) e começa a brincar com } \\
\text { a comida. A monitora conversa com ela para que } \\
\text { coma. A professora que havia terminado de dar a } \\
\text { janta para Augusto vai até Clarice para ajudá-la. } \\
\text { Clarice recusa. Professora conversa com ela. A } \\
\text { professora conversa com a monitora e com Clarice } \\
\text { dizendo que ela, Clarice, já comia os alimentos } \\
\text { sólidos e não pastosos. }\end{array}$ \\
\hline
\end{tabular}

Fonte: Diário dia da semana Clarice - Creche - registro realizado pela pesquisadora 
Passamos a tratar, a seguir, dos momentos de higiene e como já informado abordaremos na subseção "Contrastando as situações sociais relacionadas aos cuidados" os aspectos em comum entre as três situações sociais: sono, alimentação e higiene.

\subsubsection{HiGIENE}

No Diário do Uso do Tempo do dia da semana de Augusto (Quadro 6) houve o registro de 10 atividades relacionadas à higiene, que representaram $1 \mathrm{~h} 09 \mathrm{~min}$ do uso do seu tempo. Destas, ocorreram 3 atividades em $26 \mathrm{~min}$ no espaço da creche e 7 em $48 \mathrm{~min}$ no contexto familiar.

Os momentos de higiene na creche foram caracterizados por troca de fraldas, que ocorreram no período da manhã e começo da tarde. A primeira vez a troca foi realizada pela mãe em companhia da pesquisadora e teve duração de $13 \min$. Esse tempo foi determinado mais pela interação entre a mãe e a pesquisadora, do que o tempo entre a mãe e o bebê. No período da tarde, a troca ocorreu em companhia de um adulto da equipe gestora que estava ajudando na rotina do Berçário I e nela foram gastos $5 \mathrm{~min}$. O banho ocorreu no período da manhã, às $11 \mathrm{~h} 05 \mathrm{~min}$, após o almoço, com duração de $8 \mathrm{~min}$, e foi realizado na companhia da professora.

No contexto da família, os momentos de higiene são caracterizados por banho com a irmã sob os cuidados do pai com duração de $15 \mathrm{~min}$; troca de roupa em companhia da mãe e irmã; troca de fralda realizado pela mãe e pelo pai; além dos pais aproveitarem o momento em que o bebê estava dormindo para cortar suas unhas.

No final de semana (Quadro 7) há o registro de 9 atividades de higiene com duração total de 40 min. Eles são caracterizados por momentos de troca de fralda, banho e troca de roupa. A mãe descreve tanto o tempo que a criança leva para fazer suas necessidades quanto o tempo que gastam para a troca de fralda.

No Diário do Uso do Tempo do dia da semana de Clarice (Quadro 6), houve registro de 4 atividades de higiene com duração de 41 min dentro os quais 2 ocorreram na creche: troca de fraldas e banho com duração de 16min, e 2 atividades com 25 min de 
duração em casa, também sendo banho e troca de roupa. Já no final de semana (Quadro 7) há o registro de 2 atividades: banho e troca de fralda com duração total de $25 \mathrm{~min}$.

Observamos que para ambas as crianças essa é a situação em que foi usada menor quantidade de tempo. O tempo utilizado para a troca de fraldas tanto em casa quanto na creche é pequeno. Já o tempo utilizado para o banho se diferencia entre o contexto da creche e da família. Ambas as crianças utilizam mais tempo quando estão no contexto familiar, uma vez que, em casa, esse momento também é um momento lúdico. Os pais deixam que as crianças brinquem e também tomem banho em companhia dos irmãos ou dos pais, conforme Isadora, mãe de Augusto, relata na entrevista.

MÃE: [...] Às vezes, por exemplo, precisava tomar banho, aí às vezes até, muitas vezes eu levava ele comigo, né. [...] Meu chuveiro fica em cima da banheira né, então é como se fosse um lugarzinho fechadinho, então eu estando perto é seguro para ele. Às vezes ele dá umas escorregadinhas e tudo, mas é como se fosse um cercadinho, né. E aí sempre tem brinquedinho, xampu coloridinho que eu compro para eles, né, [...]. Ele gosta muito de brincar com água, né. Então eu fecho um pouquinho, deixo um pouquinho como se fosse uma piscininha e ele bate a mão, tudo [...] (Entrevista com Isadora, mãe de Augusto, 10/02/2014, linhas 317-325).

Notamos que esse tempo é menos regulado na casa do que na creche. Ainda que se perceba a interação entre as crianças e seus cuidadores, há necessidade de que o tempo nessa atividade não se estenda demasiadamente, uma vez que o momento de higiene está previsto dentro da rotina como um momento fixo. Apresentamos na subseção a seguir as características em comum dessas situações.

\subsubsection{CONTRASTANDO AS SITUAÇÕES SOCIAIS RELACIONADAS AOS CUIDADOS}

Apresentados os dados, passamos à análise das situações sociais sono, alimentação e higiene nos diferentes contextos sociais. Ao discutirmos acerca dessas situações que se caracterizam por serem "ditas" biológicas à luz de Goffman, queremos destacar o quanto estas são também reguladas socialmente. Não pretendemos negar o seu caráter biológico, mas queremos analisá-las considerando um conjunto de negociações, contextos e sujeitos envolvidos, uma vez que se apresentam como o maior uso do tempo dos bebês. 
Em cada uma dessas situações há uma série de rituais adotados, permitindo que os bebês reconheçam qual o comportamento esperado para cada uma das situações. Quando os bebês estão na creche, eles reconhecem que, após o almoço, é o momento para o descanso; assim, as luzes da sala dos berços são apagadas, os adultos falam mais baixo, entoam canções de ninar, balançam o bebê conforto e ligam o ventilador. Em casa, os pais relatam que gastam tempo para fazer os bebês dormirem.

Nos quadros de alimentação e higiene também é possível reconhecer marcadores que caracterizam essas situações. Na creche a comida é trazida por uma funcionária da cozinha e os adultos costumam festejar esse momento com as crianças. Um dos principais elementos de ancoragem dessa situação é a chegada da comida no carrinho conduzido pela funcionária; outro elemento é a organização da sala: os adultos contam com a ajuda de algumas crianças para disporem os cadeirões no espaço da sala principal.

Percebemos no Diário de Augusto (Quadro 12) que ele, assim como os outros bebês da turma, se deslocam para o espaço em que ficam os cadeirões ao perceberem a chegada do café da manhã.

Quadro 12 - Augusto café da manhã

\begin{tabular}{|c|c|c|c|c|l|}
\hline Atividade & $\begin{array}{c}\text { Hora } \\
\text { início }\end{array}$ & Hora fim & Local & $\begin{array}{c}\text { Com } \\
\text { quem } \\
\text { estava }\end{array}$ & Observação \\
\hline $\begin{array}{c}\text { Foi até o } \\
\text { cadeirão }\end{array}$ & $07: 53$ & $07: 55$ & $\begin{array}{c}\text { Sala } \\
\text { principal } \\
\text { tapetão } \\
\text { de EVA }\end{array}$ & $\begin{array}{c}\text { Bebês da } \\
\text { turma }\end{array}$ & $\begin{array}{l}\text { O café da manhã chega. Grande parte das } \\
\text { crianças, ao perceberem a chegada do café, } \\
\text { começam a ir em direção aos cadeirões. } \\
\text { Augusto também começou a engatinhar em } \\
\text { direção aos cadeirões [...] }\end{array}$ \\
\hline
\end{tabular}

Fonte: Diário dia da semana Augusto - Creche - registro pesquisadora

Já no Diário de Clarice é possível observar que ela festeja com os adultos a chegada do carrinho, bem como acompanha a monitora na disposição dos cadeirões na sala principal (Quadro 13). 
Quadro13 - Clarice almoço e café da tarde

\begin{tabular}{|c|c|c|c|c|l|}
\hline Atividade & $\begin{array}{c}\text { Hora } \\
\text { início }\end{array}$ & Hora fim & Local & $\begin{array}{c}\text { Com } \\
\text { quem } \\
\text { estava }\end{array}$ & Observação \\
\hline $\begin{array}{c}\text { Almoço } \\
\text { chega }\end{array}$ & $10: 43$ & $10: 49$ & $\begin{array}{c}\text { Sala } \\
\text { principal }\end{array}$ & $\begin{array}{c}\text { Monitora, } \\
\text { 2 bebês }\end{array}$ & $\begin{array}{l}\text { Clarice acompanha monitora ao colocar os } \\
\text { cadeirões na sala e permanece perto da } \\
\text { monitora até ser colocada no cadeirão [...] }\end{array}$ \\
\hline $\begin{array}{c}\text { Café da } \\
\text { tarde chega }\end{array}$ & $13: 32$ & $13: 42$ & $\begin{array}{c}\text { Sala } \\
\text { principal }\end{array}$ & Monitora & Ela bate palmas.[...] \\
\hline
\end{tabular}

Fonte: Diário dia da semana Clarice - Creche - registro realizado pela pesquisadora

Em casa, igualmente, o momento de alimentação possui seus marcadores. Acontece em espaços específicos da casa, como, por exemplo, na cozinha. Em geral, as mães são as responsáveis por esse momento e, então, os bebês as acompanham ou ficam na companhia dos pais.

Em relação aos marcadores que caracterizam a ancoragem dos quadros de higiene podemos apontar que foram mais difíceis de localizar nos Diários, contudo houve um que chamou nossa atenção. Clarice, após tomar o café da manhã, vai até a professora para que ela olhasse sua fralda (Quadro 14).

Quadro 14 - Higiene Clarice

\begin{tabular}{|c|c|c|c|c|c|}
\hline Atividade & $\begin{array}{c}\text { Hora } \\
\text { início }\end{array}$ & Hora fim & Local & $\begin{array}{c}\text { Com } \\
\text { quem } \\
\text { estava }\end{array}$ & Observação \\
\hline $\begin{array}{c}\text { Monitora } \\
\text { coloca } \\
\text { Clarice no } \\
\text { cadeirão }\end{array}$ & $08: 16$ & $08: 30$ & $\begin{array}{c}\text { Sala } \\
\text { principal }\end{array}$ & $\begin{array}{c}\text { Monitora } \\
\text { e bebê }\end{array}$ & $\begin{array}{c}\text { [...] Clarice vai até a professora, que está no } \\
\text { outro lado da sala, para ela olhar sua fralda. }\end{array}$ \\
\hline
\end{tabular}

Fonte: Diário dia da semana Clarice - Creche - registro realizado pela pesquisadora

Assim, destacamos que o cenário rotineiramente organizado pelos adultos permite que os bebês saibam qual o comportamento esperado deles em cada situação. Goffman (2012b) afirma que a delimitação temporal dos episódios está estreitamente associada às modalidades da ancoragem da atividade que a caracteriza, isto é, as condições que permitem fixar ou situar a atividade fornecem os recursos materiais, humanos e simbólicos que tornam a situação viável e identificável para os participantes.

Os comportamentos esperados em cada situação são denominados por Goffman (2010) como sendo o ethos, ou seja, em uma determinada ocasião social, o indivíduo age e se comporta conforme o esperado. Segundo o autor (2010, p. 29), cada ocasião possui 
um "[...] ethos distintivo, um espírito, uma estrutura emocional que precisa ser criada, mantida e desfeita apropriadamente de forma que o participante perceba que ele é obrigado a ser tomado pela ocasião".

Outros estudos como os de Batista (1998), Coutinho (2002) e Barbosa ( 2006) também discutem como a ordem institucional impõe posturas para as ações das crianças. Coutinho (2002) chama atenção para os diversos mecanismos que a creche cria para conduzir as ações das crianças que, apesar de resistirem, acabam por se acomodar diante da interferência constante dos adultos nos seus empreendimentos. Para a autora, o sono é o momento da rotina da creche em que a ritualização aparece de forma mais intensa. $\mathrm{Ou}$ seja, alguns procedimentos costumam ser repetidos antes de colocar os bebês para dormir, como: diminuir a luminosidade, canções de ninar, etc.

Contudo, observamos que não necessariamente essas ações ocorrem da mesma forma sempre, pois, como afirma Barbosa (2006, p.37), o cotidiano se diferencia da rotina, pois "[...] é nele que acontecem tanto as atividades repetitivas, rotineiras, triviais, como também é o locus onde há a possibilidade de encontrar o inesperado". A exemplo, do que ocorre no momento do sono de Clarice na instituição de Educação Infantil (Quadro 10), ela dormia todos os dias com sua chupeta, contudo, devido às recomendações médicas, a mãe não levou o objeto para instituição, então a professora passou cerca de 30min negociando com ela para que ela dormisse.

Coutinho (2002, p. 78) discute que a busca pela homogeneidade é rompida pelo imaginário das crianças que, "[...] perante as ações constantes, elas buscam ora a ruptura, ora a acomodação" e que os desencontros entre os desejos, vontades e necessidades torna a educação uma intensa prova de resistência.

Como Coutinho (2002) afirma, é necessário considerar a diversidade de desejos e ritmos das crianças. É certo que o que predomina nas instituições de Educação Infantil é a organização do tempo pelos adultos, atendendo muito mais às suas necessidades do que às das crianças, contudo as crianças sempre estão buscando espaços para expressar seus desejos e necessidades.

Observando os quadros que caracterizam a situação social do sono de Augusto na creche, nota-se que há uma ruptura com a rotina da instituição. Ele dormiu antes do 
almoço e enquanto a maioria das crianças já estava acordada. Ele dormiu na sala de atividades e não na sala de berços, então seu sono foi interrompido em um primeiro momento por outro bebê e depois por um adulto.

Sob a perspectiva de Goffman, podemos analisar esse quadro como uma fuga ao papel esperado, mas que, ao final, possibilita novas construções e relações entre os indivíduos, dando dinamicidade, renovação e redefinindo comportamentos esperados. Nesse sentido, Coutinho (2010, p. 100) afirma que a recursividade dada pela rotina "[...] revela um domínio da ação e a possibilidade de sua alteração e da alteração da estrutura à medida que esse tempo é vivido".

Guimarães (2011, p.130), corrobora esta tese e afirma que a dimensão rotineira, o que é realizado todos os dias, permite a emergência do novo, do diferente. $O$ reconhecimento da alteridade das crianças e a identificação de momentos em que superam o ritmo homogêneo imposto a elas fornecem os elementos necessários para a alteração da rotina.

Nesse sentido, analisando os dados, podemos questionar se o sono, a alimentação e higiene seguem somente o ritmo biológico. Gottlieb (2012) demonstra como comportamentos entendidos como biológicos podem na verdade "[...] revelar dados culturalmente ricos" (GOTTLIEB, 2012, p. 324). Por exemplo: a habilidade de sentar que, na sociedade ocidental normalmente é esperada dos bebês aos 8 meses de idade, é conquistada pelos bebês Baganda, em geral, a partir dos 4 meses de idade. Isso porque os Baganda adultos estimulam que seus bebês comecem a sentar a partir de um mês de idade, pois, ao conseguirem fazer isso com autonomia, podem sentar, sorrir e comunicar-se com quem está à sua volta.

Em nossos dados, o que determina, em grande parte, os tempos das situações que os bebês participam são as regulações sociais. Nos Diários de ambos os bebês, exceto pelo dia em que Augusto esteve doente, o que determinou os tempos foram as relações estabelecidas no decorrer das 24horas.

Ao compararmos as situações de sono, alimentação e higiene entre o dia da semana e o do final de semana, podemos afirmar que, nesse caso, elas já fazem parte das experiências socioculturais e não apenas biológicas das crianças. Ainda que os pais 
tentem manter os mesmos horários em que essa situação ocorria na creche, nem sempre conseguiam devido à imprevisibilidade das situações que podiam ocorrer durante um dia.

No caso de Augusto, os quadros de sono que ocorrem durante o dia são feitos em horários muitos distintos dos que ocorrem na creche. O mesmo ocorre em relação ao sono da noite, quando se observa uma tentativa dos pais de manter um padrão para o horário de dormir. Contudo, a mãe afirma que esse horário pode variar conforme a agenda dos pais, e o horário que o bebê vai dormir pode variar entre $2 \mathrm{~h}$ ou mais:

MÃE: Assim, à noite ele em geral dorme por volta de $08 \mathrm{~h} 30 \mathrm{~min}$ ou $09 \mathrm{~h}$, e
acorda no dia seguinte. Quando tem aula, né, acorda $07 \mathrm{~h} 30 \mathrm{~min}$, geralmente,
que é a hora que eu pego ele para vir para a escola, né. Em casa assim, por
exemplo, a gente sai, vai para algum lugar assim e aí ele dorme um pouquinho
mais tarde. Só que na semana, em geral, à noite eu fico em casa né. Quando eu
vou à igreja, à noite, aí a gente chega por volta de 10 horas e aí ele dorme mais
tarde. Âs vezes, eu vou uma vez por semana à noite, mas não tenho ido muito
durante a semana não. É mais no fim de semana. Aí ele dorme em geral nesse
horário $08 \mathrm{~h} 30$ min, $09 \mathrm{~h}$, a mais tardar $09 \mathrm{~h} 30$ min (Entrevista com Isadora, mãe
de Augusto, 10/02/2014, linhas123-129).

Já Carolina, mãe de Clarice, explica que a própria criança pede para dormir quando chega o horário em que ela normalmente dorme.

MÃE. Ela pede para dormir também, fica nervosa, às vezes ela chora, se ela
não deitar ela fica nervosa; ela gosta de deitar para dormir, ela não gosta de
dormir no colo, ela não é. Quando a gente está em casa e eu quero assistir um
pouquinho, mas se eu pego ela no colo para pegar ela para dormir, ela não quer.
Ela me puxa, pega pela mão para ir pra cama, ela não fica, não gosta de dormir
no colo ou em pé, nem na rua. Na rua, se a gente estiver passeando ou coisa
assim, ela chora até na hora de chegar em casa para poder deitar na cama para
dormir. (Entrevista com Carolina, mãe de Clarice, 11/02/2014, linhas 94-99).

Observamos que os quadros de sono de Clarice possuem uma regularidade maior do que os de Augusto, contudo a mãe informa que ela gasta um tempo com a criança "fazendo ela dormir". Assim como ocorre na creche, são criadas condições favoráveis para que a criança durma no horário estipulado.

Coutinho (2010, p. 128-9) afirma:

[...] mesmo que ao nascer o bebê tenha reações corpóreas que são fruto de seu instinto, ele vai progressivamente, e muito cedo, tendo manifestações que são elaboradas a partir das suas experiências socioculturais.

Nessa mesma linha, Goffman (2012b) considera ser a natureza humana um conjunto de regras morais impressas no indivíduo por meio dos encontros sociais. 
A natureza humana universal não é uma coisa muito humana. Ao adquiri-la a pessoa torna-se uma espécie de construto, criada não a partir de propensões psíquicas internas, mas de regras morais que são carimbadas nela externamente. Essas regras, quando seguidas, determinam a avaliação que ela fará sobre si mesma e sobre seus colegas participantes no encontro, a distribuição de seus sentimentos, e os tipos de práticas que ela empregará para manter um tipo especificado e obrigatório de equilíbrio ritual. A capacidade geral de ser limitado por regras morais pode muito bem pertencer ao indivíduo, mas o conjunto particular de regras que o transforma num ser humano é derivado de requerimentos estabelecidos na organização ritual de encontros sociais (GOFFMAN, 2012b, p. 49).

Podemos ilustrar essa mudança de comportamento também pelo relato de Isadora, mãe de Augusto, acerca das vezes que o bebê acordava para mamar e com o passar do tempo ele adquire mais autonomia para pegar a chupeta, deixando de mamar durante a noite.

MÃE: Ele divide com a irmã o quartinho. Só que ele é assim: ele dorme no berço, mas tem vezes que eu tiro. Tem horas que eu não aguento não, porque ele é assim, ele tem muito essa mania de acordar, ele dá uma choramingadinha, toma o leite e dorme. É até um costume que eu estou tentando aos poucos tirar, né. Mas ele, nessa época ele não sabia ainda, ele não conseguia pegar a chupeta e pôr na boca. Hoje em dia ele já faz isso. Então, quando ele acorda, ele mesmo caça assim, dá uma resmungada, pega a chupeta, põe na boca e volta a dormir. Nessa época não. Se ele acordasse, ele só voltava a dormir com a chupeta. Aí eu tinha que levantar, ir lá ao quarto e pegar. Então tinha vezes que eu acordava cinco vezes à noite ou seis. Aí eu falava “ah quer saber, não estou nem aí não, dorme aqui logo que pelo menos eu descanso" (risos). Então assim, ele dormia algumas vezes no quarto, algumas vezes com a gente. [...] (Entrevista com Isadora, mãe de Augusto, 10/02/2014, linhas 146-160).

Percebemos pela fala da mãe que, na época da entrevista, ele já tinha autonomia para colocar a chupeta na boca, deixando de lado o choramingar . Conforme relatado no Diário, ele acordava muitas vezes e mamava um pouco, mas, sobretudo, utilizava a mamadeira como chupeta. Podemos destacar nessa situação, a atividade primária de mamar transformada/tonalizada em uma atividade de apego a um objeto. Nesse sentido, a atividade é transformada novamente, a maior autonomia motora do bebê juntamente com a iniciativa da mãe de tentar mudar o hábito do bebê, modificar a ação que era de choramingar e receber atenção dos pais, para uma ação do bebê de pegar a chupeta e voltar a dormir.

Nesta seção buscamos discutir, com base na perspectiva de Goffman, as situações sociais vivenciadas pelos bebês que comumente são reconhecidas como tipicamente biológicas, mas que, no cotidiano os bebês, são transformadas e adaptadas às suas 
diferentes necessidades. Igualmente buscamos explicitar que há uma série de fatores do contexto que vão adicionar uma nova camada de significados para essas situações.

\subsection{BRINCADEIRAS NA CRECHE E NA FAMÍLIA}

Nesta subseção vamos tratar das situações de brincadeira, que esteve presente em todos os Diários, tanto no contexto da creche quanto no da família. No Diário de Augusto do dia da semana foram registrados 49 momentos envolvendo a brincadeira, totalizando 3h26min, sendo que 43 destes, com duração total de $2 \mathrm{~h} 05 \mathrm{~min}$, ocorreram enquanto ele esteve no espaço da creche, e 6 momentos, com duração total de $1 \mathrm{~h} 21 \mathrm{~min}$, no período em que esteve com a família. No final de semana transcorreram 18 momentos, totalizando 4h43min (Quadro 15).

Já no Diário do dia da semana de Clarice ocorreram 40 registros dessa situação, totalizando 5 h20min, sendo que 38 atividades com duração total de $3 \mathrm{~h}$ transcorreram no espaço da creche e, 2 atividades com duração total de $2 \mathrm{~h} 20 \mathrm{~min}$ na casa. No final de semana ocorreu o registro de 6 momentos, totalizando 4h15min (Quadro 15).

Quadro 15 - Brincadeira - Uso do tempo total

\begin{tabular}{|c|c|c|c|}
\hline \multicolumn{4}{|c|}{ Augusto } \\
\hline & & Duração & Quadros \\
\hline \multirow{2}{*}{$\begin{array}{l}\text { Dia da } \\
\text { semana }\end{array}$} & Creche & $02: 05$ & 43 \\
\hline & Casa & $01: 21$ & 6 \\
\hline $\begin{array}{l}\text { Final de } \\
\text { semana }\end{array}$ & Casa & 04:43 & 18 \\
\hline
\end{tabular}

\begin{tabular}{|l|c|c|c|}
\hline \multicolumn{4}{|c|}{ Clarice } \\
\hline & & Duração & Quadros \\
\hline $\begin{array}{l}\text { Dia da } \\
\text { semana }\end{array}$ & Creche & $03: 00$ & 38 \\
\cline { 2 - 4 } $\begin{array}{l}\text { Final de } \\
\text { semana }\end{array}$ & Casa & $02: 20$ & 2 \\
\hline
\end{tabular}

Fonte: corpus de pesquisa

Esses dados estão relacionados aos dados registrados nos Diários no campo "Atividade" como sendo: brincar, brincando, brincando com ..., além das atividades as quais, em um primeiro momento, não foram enquadradas como atividade primária, mas que, a partir dos dados registrados nas "Observações" e entrevistas, permitiram que caracterizássemos a situação como brincadeira. Percebemos, em nossos dados, uma diversidade na classificação e entendimento sobre o brincar, o que gerou diferentes enquadramentos pelas participantes da pesquisa. Por isso, faz-se necessário estabelecer inicialmente de qual definição do brincar estamos tratando. Em seguida, apresentaremos 
como as mães caracterizaram o brincar e, depois, analisaremos os dados à luz do repertório teórico.

O brincar, muitas vezes, é associado a uma "atividade inata, inerente à natureza da criança” (WAJSKOP, 1995, p. 63). Ciências como a Psicologia e a Fisiologia contribuíram para divulgação dessa ideia (WAJSKOP, 1995; HUIZINGA, 2000). Contudo, como afirma Huizinga (2000), há uma grande divergência nas tentativas de definição biológica do jogo.

\begin{abstract}
Umas definem as origens e fundamento do jogo em termos de descarga da energia vital superabundante, outras como satisfação de um certo "instinto de imitação", ou ainda simplesmente como uma "necessidade" de distensão. Segundo uma teoria, o jogo constitui uma preparação do jovem para as tarefas sérias que mais tarde a vida dele exigirá, segundo outra, trata-se de um exercício de autocontrole indispensável ao indivíduo. Outras vêem o princípio do jogo como um impulso inato para exercer uma certa faculdade, ou como desejo de dominar ou competir. Teorias há, ainda, que o consideram uma "abreação", um escape para impulsos prejudiciais, um restaurador da energia dispendida por uma atividade unilateral, ou "realização do desejo", ou uma ficção destinada a preservar o sentimento do valor pessoal etc (HUIZINGA, $2000, \mathrm{~s} / \mathrm{n}$, grifos do autor).
\end{abstract}

Autores como Ariès (1981) e Brougère (1998) nos chamam a atenção para o caráter social dessa atividade. Para Brougère (1998, s/n), “[...] brincar não é uma dinâmica interna do indivíduo, mas uma atividade dotada de uma significação social precisa que, como outras, de aprendizagem". Nesse sentido, o brincar recebe diferentes significações de acordo com o contexto social, histórico e cultural em que está inserido.

Ariès (1981), em suas análises da iconografia, afirma que, na sociedade antiga, os jogos tinham um significado diferente do que atribuímos hoje, pois "[...] formavam um dos principais meios de que dispunha uma sociedade para estreitar seus laços coletivos, para se sentir unida" (ARIÈS, 1981, p. 51). Contudo, os jogos passaram a ser recriminados pelos moralistas e pela igreja, que os associavam aos prazeres carnais, ao vício e ao azar.

Segundo o autor, essa atitude de reprovação mudou ao longo do século XVII, principalmente sob a influência dos jesuítas, que passaram a destacar as possibilidades educativas dos jogos. Dessa forma, os padres propuseram assimilá-los a seus programas com a condição que pudessem ser regulamentados e controlados. Ariès (1981) afirma que os jogos, ao serem disciplinados, passam a ser reconhecidos como bons, sendo admitidos e recomendados. A partir de então, passam a ser considerados "[...] como meios de educação tão estimáveis quanto os estudos" (ARIÈS, 1981, p. 65). 
Os jogos disciplinados passaram a ser associados aos exercícios físicos, sendo recomendados como os melhores tipos de atividades. Wajskop (1995) afirma que essa nova configuração os levou a serem " [...] cada vez mais especializados, de acordo com as idades e o desenvolvimento infantil. A brincadeira, como um comportamento infantil e espontâneo, ganhou um valor em si” (WAJSKOP, 1995, p. 63).

Estudos da infância, nas últimas décadas, têm destacado o brincar como um conceito central, uma vez que, por meio deste, os pesquisadores conseguem dar destaque às ações das crianças. Por meio das brincadeiras das crianças se tem acesso ao seu mundo social, fornecendo assim um dos contextos mais importantes para a investigação focada na criança (JAMES; JAMES, 2008; COUTINHO, 2013).

Pesquisas como a de Fernandes (2004) e de Corsaro (2011) estabeleceram alguns marcos importantes para os estudos da infância ao dar destaque, por meio da brincadeira, à cultura infantil e à reprodução interpretativa de pares. Os autores analisam como as crianças participam ativamente da cultura em que estão envoltas, não se limitando à simples imitação ou à mera reprodução das ações dos adultos e sim apropriando-se das informações do mundo adulto e construindo ativamente a sua cultura.

Neste trabalho, adotamos a perspectiva da brincadeira como atividade social, dotada de significado a partir e na relação com uma dada cultura. Como afirma (BROUGÈRE, 1998, s/n), “[...] o jogo só existe dentro de um sistema de designação, de interpretação das atividades humanas". Assim, o enquadramento de uma atividade como brincadeira vai depender da interpretação que os atores sociais fazem dela.

Coutinho (2013, p. 40) corrobora com esta ideia e afirma,

As diferentes classificações e denominações relativas ao brincar tomam por base os repertórios e diferentes modos de estruturação das brincadeiras pelas crianças, que recorrem a variados recursos sociais e culturais - simbólicos e materiais - para suas elaborações.

Como sugerimos inicialmente, notamos uma diversidade na classificação e entendimento sobre como o brincar foi registrado nos Diários. As entrevistas foram de suma importância para gerar dados complementares, pois nos permitiram compreender quais elementos as mães utilizaram para produzir o recorte dessa atividade dos bebês. 
Passamos a analisar, a seguir, como as mães caracterizam o brincar. Na sequência, cruzaremos esses dados com os produzidos pela pesquisadora.

No Diário de Clarice, no que diz respeito aos registros realizados pela mãe, a brincadeira é caracterizada pelos momentos em que a criança explorou algum brinquedo, quando esteve na presença de alguma outra criança, quando foi para algum espaço especializado para a brincadeira - nesse caso o parquinho, ou também pelo tempo estruturado pelos pais para que essa situação ocorresse. Por exemplo, é ilustrado no Quadro 16, em que o pai sai com a filha para a frente da casa para que ela brincasse.

Quadro 16 - Exemplo de registro da brincadeira no Diário de Clarice

\begin{tabular}{|c|c|c|c|c|c|}
\hline Atividade & $\begin{array}{c}\text { Hora } \\
\text { início }\end{array}$ & $\begin{array}{c}\text { Hora } \\
\text { Fim }\end{array}$ & Local & $\begin{array}{c}\text { Com que } \\
\text { estava }\end{array}$ & Observação \\
\hline Brincando & $19: 00$ & $20: 00$ & $\begin{array}{c}\text { Frente de } \\
\text { casa }\end{array}$ & Pai & --------- \\
\hline
\end{tabular}

Como já antes informado, os participantes da pesquisa, ao descreverem as atividades no Diário do Uso do Tempo, podem omitir informações. A mãe de Clarice nos informou nos Diários que as atividades da criança estão ligadas aos cuidados pessoais ou ao brincar. Compreendemos as omissões nos registros das atividades das crianças, mas, ao descrever o que o bebê faz em um período de 24 horas, a mãe também deu destaque àquelas atividades que considerou importante. Assim, observamos que ela define como "ofício da criança"19 o brincar. Pois o bebê, quando não estava envolvido nas atividades de cuidados pessoais, está brincando. A mãe relatou na entrevista que a criança, ao chegar em casa nos dias de semana, brincava; após essa atividade, ela dormia.

MÃE. Quando a gente chega em casa, ela brinca no máximo até oito, oito e meia, aí quando já dá nove horas ela já pede para dormir, ela mesmo pede, aponta para cama e pede para "mimi" [...] (Entrevista com Carolina, mãe de Clarice, 11/02/2014, linhas 92-93).

No Diário de Augusto, a brincadeira é caracterizada por momentos em que ele estava brincando com a irmã, que estava na presença de alguma outra criança ou que brincou com algum objeto. A mãe informou na entrevista que, na data da primeira geração

\footnotetext{
19 Termo cunhado por Chamboredon e Prévot (1986) para explicitar as funções sociais que as instituições de
} atendimento à primeira infância devem desempenhar enquanto lócus de socialização e de aprendizagem. 
dos dados, ele não achava muita graça em brincar, se interessava mais em acompanhar as ações da mãe.

MÃE: [...] Era uma época que ele não achava ainda muita graça em brincar. Hoje em dia ele já fica mais explorando o ambiente, brincando, senta com a irmã para brincar, só que nessa fase ele ainda estava naquela fase muito individualista assim, né, então ele não achava muita graça em brincar com a irmã, e não achava muita graça em brincar sozinho. Então ele andava, mexia, pegava uma coisinha, ia lá à cozinha, abria armário, essas coisas, e queria colo. Era o tempo todo, ele ficava no máximo cinco a dez minutinhos assim, sozinho... Então o tempo todo ele queria colo, era uma fase que ele queria muito ficar comigo assim, o tempo todo ele querer ficar no meu colo e eu não conseguia fazer quase nada [...] (Entrevista com Isadora, mãe de Augusto, 10/02/2014, linhas 202-209).

Segundo a mãe, ele não tinha muito interesse em brinquedos como carrinhos, bloquinhos e se interessava por objetos que faziam barulho:

MÃE: [...] Então naquela época ele não gostava muito de brinquedo não, ele gostava de celular, coisas eletrônicas. E brinquedos ele gostava mais dos que faziam barulho: chocalho. Ele tem lá uns brinquedinhos que são tipo, uns instrumentinhos musicais, umas cornetinhas, todos um barulho insuportável. Então ele soprava assim, né, soprava, puxava o ar e fazia o barulhinho, então ele gostava mais disso. Esses brinquedinhos que fazem barulho, coisinha eletrônica e coisinha pequena para enfiar na boca, era um perigo. Qualquer coisinha pequena assim, tudo ele enfiava na boca (risos). Nessa fase era mais isso o que ele gostava. Não gostava muito assim de brinquedo não. Carrinho, essas coisas não. Bloquinho, ele não gostava nessa época (Entrevista com Isadora, mãe de Augusto, 10/02/2014, linhas 234-241).

Essa leitura da mãe está ligada ao que Brougère (2004) trata como sendo cultura lúdica. Para o autor o objeto carrega uma cultura lúdica, ou seja, “[...] um conjunto de esquemas, de regras e de imagens" (Brougère, 2004, p. 262) ligadas à cultura em que está envolto. Assim, a mãe esperava um determinado comportamento frente às imagens que ela tinha acerca da função dos objetos. Como Augusto não utilizava os objetos da forma esperada ou não se interessa por eles a mãe afirma que Augusto passava pouco tempo brincando:

MÃE: Brincando? Pouquíssimo. Era coisa assim no máximo uns quatro minutinhos, cinco no máximo. Ele andava, dava uma voltinha na casa, e aí queria colo. Era sempre assim, ele não ficava muito tempo com uma coisa. Hoje em dia ele já fica mais, hoje em dia ele, às vezes, fica dez, quinze minutos brincando com a irmã assim, de vários bonequinhos. Aí ele vê a irmã com as bonecas, de vez em quando ele pega, ele não é muito fã de boneca não, mas de vez em quando ele pega, ele gosta de tirar as roupas das bonecas e vestir, tentar vestir, puxar o cabelo das bonecas, ele gosta mais para puxar. (Entrevista com Isadora, mãe de Augusto, 10/02/2014, linhas 258-263).

As mães compreendem de formas diferentes o brincar dos bebês. Para a mãe de Clarice, cada membro da família tem uma função social, o que gera ocupações de tempo 
com atividades diferentes para cada um. Por exemplo, a criança brincava enquanto a mãe preparava o jantar ou saía para brincar no parquinho enquanto a mãe tomava banho e depois preparava o jantar.

Já para a mãe de Augusto a brincadeira é caracterizada, principalmente, pelos momentos em que ele estava brincando com algum dos seus pares, como, por exemplo, brincar de rolar no tapete com a irmã. $\mathrm{Na}$ época da primeira geração dos dados, a mãe afirma que Augusto detinha-se pouco tempo nas atividades de brincadeira.

Para Brougère (1998, s/n), a brincadeira se insere num sistema de significações. Para que uma atividade seja uma brincadeira "[...] é necessário então que seja tomada e interpretada como tal pelos atores sociais em função da imagem que têm dessa atividade" (BROUGÈRE, 1998, s/n). Recorrendo ao repertório teórico de Goffman, podemos afirmar que era esperado dos envolvidos na situação - os que estavam assistindo e os que estavam atuando - uma determinada linha de comportamento. A mãe de Augusto esperava que o bebê mantivesse uma determinada linha para que ela pudesse caracterizar a situação como brincadeira, mas o bebê, segundo a visão dela, fugia dela.

Para ambas as mães o brincar se configurou por momentos em que os bebês estavam com algum artefato cultural criado especificamente para o brincar. Ambas identificaram os objetos de que as crianças mais gostavam. Para Augusto, eram brinquedos que produziam barulho, que podiam ser levados à boca e objetos eletrônicos dos adultos, como celulares. No entanto, a mãe identificou que Augusto não tinha interesse por todos os brinquedos disponíveis para ele. Já Carolina, mãe de Clarice, informou que a menina tinha um cesto de brinquedos que fica à sua disposição, e que, dentre os brinquedos ofertados, o que ela mais se interessava era o cavalinho de pau.

MÃE. Ela tem uns brinquedinhos, é... um cavalinho desse tamanho, tem um cesto de brinquedo, e ela gosta de pintar, de desenhar, é assim

PESQUISADORA. Ela tem algum que ela goste mais, que ela sempre acaba brincando?

MÃE. É o cavalinho, ela chama de Totó, ela pega ele e aí monta nele aí fica "Mãe, Totó", aí fica brincando com ele. É o que ela brinca mais (Entrevista com Carolina, mãe de Clarice, 11/02/2014, linhas 193-198).

$\mathrm{Na}$ atualidade o brincar é fortemente associado ao brinquedo industrializado. Como Brougère (1998, p. s/n), afirma, uma “[...] das características de nosso tempo é a 
multiplicação dos brinquedos”. Esses objetos portadores de ações e de significações instituem uma forma 'adequada' e 'normal', determinando as condutas que os usuários devem ter. Assim, ao ofertarem o brinquedo para os bebês, os pais esperavam que estes o explorassem de uma determinada forma, bem como demonstrassem interesse pelo objeto. Esses artefatos culturais possuem um forte apelo para a contribuição ao desenvolvimento de capacidades e habilidades, sendo, em muitos casos, associados a funções educativas. Como Brougère (2004) afirma, as imagens e textos que dão suporte aos brinquedos são destinados, antes de tudo, aos adultos (pais), que neles encontram representações que se harmonizam com a imagem que têm da criança.

Ambas as mães destacaram os jogos que aconteceram entre os bebês, pares e adultos. Tanto Augusto como Clarice têm irmãos mais velhos, que se tornaram, em muitos momentos, seus parceiros de brincadeira, além de outras crianças com quem conviviam, como amigos ou primos. Vamos discutir a importância dos parceiros para a brincadeira mais à frente.

Destacamos até aqui as atividades registradas pelas mães recortadas como brincar. Passaremos, a seguir, a analisar os dados que foram registrados pela pesquisadora, buscando cruzar as informações como essas situações ocorreram tanto no espaço da creche como no familiar. Utilizaremos os conceitos de esquema primário e tonalizações de Goffman para tratarmos da diversidade das brincadeiras dessa situação e permitir que apresentemos a análise de forma mais clara.

Definimos o esquema primário da brincadeira como sendo o momento em que a criança estava manipulando algum brinquedo disponibilizado pelo adulto com a função convencional de ser um objeto para as crianças brincarem. Como informado no Quadro 17 do Diário do dia da semana de Augusto. 
Quadro 17 - Exemplo esquema primário de brincadeira

\begin{tabular}{|c|c|c|c|c|l|}
\hline Atividade & $\begin{array}{c}\text { Hora } \\
\text { início }\end{array}$ & $\begin{array}{c}\text { Hora } \\
\text { fim }\end{array}$ & Local & $\begin{array}{c}\text { Com quem } \\
\text { estava }\end{array}$ & \multicolumn{1}{c|}{ Observação } \\
\hline $\begin{array}{c}\text { Engatinha } \\
\text { até o } \\
\text { carrinho (de } \\
\text { sentar) }\end{array}$ & $10: 30$ & $10: 39$ & $\begin{array}{c}\text { Sala } \\
\text { principal }\end{array}$ & Adriano & $\begin{array}{l}\text { Ficou explorando 2 carrinhos de empurrar } \\
\text { e sentar. Outra criança se aproximou. } \\
\text { Augusto estava com um chocalho na mão } \\
\text { que ficava colocando e tirando dentro do } \\
\text { carrinho. Adriano observou e mexeu no } \\
\text { carrinho. O carrinho virou, Augusto } \\
\text { começou a mexer no outro carrinho que } \\
\text { estava ao seu lado. Adriano continuou a } \\
\text { mexer no carrinho que estava "deitado" e } \\
\text { encostou no pé de Augusto. Ele repetiu esse } \\
\text { movimento observando que Augusto } \\
\text { sempre mexia o pé quando ele encostava o } \\
\text { brinquedo. }\end{array}$ \\
\hline
\end{tabular}

Essa situação ocorreu em 25 quadros, totalizando 1h08min em relação ao dia da semana de Augusto. Essa configuração do brincar não foi encontrada no registro no Diário do dia da semana no período em que ele esteve no contexto familiar. No Diário do final de semana, houve o registro de 5 quadros com duração total de $52 \mathrm{~min}$.

No Diário de Clarice ocorreram 14 quadros, totalizando 1h18min no dia da semana. Assim, como no Diário de Augusto, essa configuração do brincar não foi encontrada no período em que ela esteve no contexto familiar durante a semana. No final de semana ocorreram 3 atividades com duração total de $1 \mathrm{~h} 55 \mathrm{~min}$.

Apesar dessa especificidade não ocorrer no registro realizado pelas mães, sabemos que essas situações ocorriam com os bebês. Como, por exemplo, no Diário de Clarice é provável que tenha ocorrido apenas a omissão e a falta de detalhamento da situação, pois a mãe informou na entrevista que, quando Clarice chegava em casa, normalmente brincava e depois dormia.

$\mathrm{Na}$ creche, nos dois dias observados, os brinquedos ficaram disponíveis para os bebês praticamente todo o período. No momento da entrada, uma caixa com brinquedos era disponibilizada. Os brinquedos, em grande parte, eram de plástico e alguns poucos de tecido, sendo eles: diferentes tipos de chocalhos, bonecos de plástico e tecido, animais, carrinhos em que os bebês podiam sentar, carrinho para encaixar peças, livro de plástico, peças de jogos de encaixe, além de alguns artefatos produzidos pelos adultos, como garrafa pet preenchida com feijão. Alguns brinquedos diferentes foram ofertados no dia 
observado para o preenchimento do Diário de Clarice. Nesse dia, alguns brinquedos novos haviam sido comprados para turma do Berçário I, sendo eles: cavalinho de plástico em que os bebês podiam sentar e balançar, piscina de bolinhas e João Bobo.

Observamos que as brincadeiras com objetos, em grande parte, proporcionaram encontros com os pares ou com os adultos. Isso ocorria na maioria das vezes a partir de um jogo de olhares, movimento e manipulação.

No espaço da creche, o brinquedo mais recorrente nas brincadeiras de Augusto foi o carrinho em que os bebês podiam sentar. No decorrer do dia ocorreram 6 quadros (25 min). O Quadro 17, Diário de Augusto, ilustra uma de suas brincadeiras com esse artefato. Augusto começou brincando sozinho com o carrinho, quando Adriano chegou; eles trocaram olhares. Adriano observou o que Augusto estava fazendo. Adriano começou a manipular o carrinho depois que ele virou. A brincadeira com os carrinhos terminou no momento em que Adriano se direciona para outra situação, contudo a interação das duas crianças não termina, apenas muda para uma outra situação.

A brincadeira descrita acima se configura numa tonalização da situação do brincar. O objeto foi criado com a função de servir para os bebês sentarem e os adultos empurrarem. Contudo, quando os bebês estavam em posse desses objetos convencionais, os utilizavam de acordo com as suas necessidades e habilidades.

Nem todas as brincadeiras ocorreram com artefatos culturais criados com essa função. No Diário de Clarice notamos que as brincadeiras mais recorrentes foram com objetos não convencionais. Algumas das brincadeiras dos bebês ocorreram com folhas de árvores que ficavam espalhadas pelo solário, baldes de fraldas vazios, copo de água, roupas e calçados dos bebês.

Dentre as brincadeiras de Clarice com objetos, a mais recorrente foi com o copo de água. A brincadeira com esse objeto repetiu-se 4 vezes (14min) no período em que esteve na creche. Essa situação iniciou-se como a brincadeira de movimentar o copo com os braços e desenhar movimentos no ar; acidentalmente Clarice derrubou a água. Começou a passar a mão na água caída e, em alguns momentos, a boca. A monitora percebeu a situação, guardou o copo e pegou um papel toalha para secar e conversou com Clarice; pediu para que ela ajudasse a secar. Clarice começou a passar o papel no chão 
com a monitora. Os outros momentos de brincadeira com o copo, que ocorreram durante o dia, foram similares a esse primeiro. Clarice bebia a água e brincava com o copo, o que acabava sempre por gerar uma interação com os adultos. Em um primeiro momento a brincadeira se configurou no prazer em movimentar os braços com o copo com água, mas depois se transformou em uma forma de chamar a atenção dos adultos e iniciar uma interação com eles.

Algumas das brincadeiras com objetos ocorreram quando os bebês estavam sozinhos. Autores como Tonucci (2005), Guimarães (2011) e Coutinho (2013) destacam a importância desse momento para as crianças. Tonucci (2005), defende que as crianças precisam ficar sozinhas para resolver problemas sem a interferência de um adulto, aspecto fundamental para o seu crescimento e seu desenvolvimento. Igualmente, Guimarães (2011) demonstra que estar sozinho não significa necessariamente ausência de cuidado, mas pode significar atenção a si, aprendizagem sobre si próprio, prazer de estar consigo mesmo. Coutinho (2013) afirma que o momento de estar só, desde que seja uma escolha da criança, é uma "[...] possibilidade de tirar proveito de algo, gozar da sua posse, da sua contemplação e do seu uso" (COUTINHO, 2013, p. 38). É uma forma de “[...] experimentar a dimensão individual no social" (COUTINHO, 2013, p. 39).

Assim como Corsaro (2011), Coutinho (2013), dentre outros autores compreendemos que a brincadeira de pares é uma experiência privilegiada de interação e de produção de cultura. Contudo, brincar sozinho proporciona um autoenvolvimento. Goffman (2010), ao analisar as interações que ocorrem nas diferentes situações, afirma que os indivíduos podem assumir diferentes graus de envolvimento em uma determinada situação. Dentre os envolvimentos que podem ocorrer está o autoenvolvimento, que acontece quando o indivíduo está envolvido consigo próprio. Goffman (2010) acaba focando em sua obra os autoenvolvimentos que geram constrangimentos ou geram infrações nas interações. Contudo, destacamos aqui o caráter positivo do autoenvolvimento, como forma de "experimentação individual" (COUTINHO, 2010) e “cuidado de si” (GUIMARÃES, 2011) dos bebês.

Uma outra tonalização das brincadeiras encontrada nos Diários foi a brincadeira de pares. Esses momentos se caracterizaram por situações em que o bebê estava na presença de outra criança e sua ação de alguma forma afetou ou desencadeou a ação de outro bebê, como exemplificado pelo Quadro 18 do Diário do dia da semana de Augusto. 
Quadro 18 -Tonalização - brincadeira entre pares

\begin{tabular}{|c|c|c|c|c|c|}
\hline Atividade & $\begin{array}{c}\text { Hora } \\
\text { início }\end{array}$ & $\begin{array}{c}\text { Hora } \\
\text { fim }\end{array}$ & Local & $\begin{array}{c}\text { Com quem } \\
\text { estava }\end{array}$ & Observação \\
\hline $\begin{array}{c}\text { Voltou para } \\
\text { sala }\end{array}$ & $09: 12$ & $09: 16$ & $\begin{array}{c}\text { Sala } \\
\text { principal }\end{array}$ & 2 crianças & $\begin{array}{c}\text { Todas as crianças voltaram para a sala e } \\
\text { ele foi para o armário da sala e ficou se } \\
\text { escondendo com outra criança. }\end{array}$ \\
\hline
\end{tabular}

$\mathrm{Na}$ brincadeira de pares houve o registro de 11 quadros, totalizando $33 \mathrm{~min}$ em relação ao dia da semana registrado no Diário de Augusto, no período em que esteve na creche, e 5 quadros totalizando 1h16min no período em que esteve com a família. No Diário do final de semana ocorreram 11 quadros, totalizando $2 \mathrm{~h} 53 \mathrm{~min}$.

No Diário do dia de semana de Clarice ocorreram 11 quadros, totalizando 35min no período em que esteve na creche, e 2 quadros, com duração total de $2 \mathrm{~h} 20 \mathrm{~min}$, no período em que esteve no contexto familiar. Já em relação ao registro realizado no final de semana, ocorreu 1 quadro com duração de $40 \mathrm{~min}$.

Vale destacar que a diferença existente entre o tempo gasto na creche e na casa, possivelmente, estão ligados ao recorte feito pelas produtoras das informações. Nos registros realizados pelas mães, em geral, não está especificado como se deu a brincadeira. As mães informam no campo de preenchimento do Diário "Com quem estava" que os bebês estavam na companhia dos irmãos. Ambas as mães informam nas entrevistas que precisavam estimular os irmãos a brincarem juntos.

Inúmeros estudos têm destacado a importância das brincadeiras de pares, pois como já discutido anteriormente, esse tipo de brincadeira proporciona as interações e produção de cultura. Pesquisas como as destacadas no início desse trabalho têm defendido um olhar mais atencioso sobre as interações de bebês. Elas têm afirmado que "[...] os bebês procuram as outras crianças com olhares, esboçando sorrisos e sons, tentando tocar o colega com o corpo" (BARBOSA, 2010, p. 6). Interações essas que se desenrolam em brincadeiras.

O Quadro 18 do Diário de Augusto do dia da semana ilustra essa situação. Augusto e um grupo de crianças que estavam no solário voltaram para a sala; uma das crianças estava em uma brincadeira com um dos adultos de esconder-se na lateral do armário. Augusto observava a cena e também começou a brincar de esconder-se e essa 
brincadeira se estendeu por $4 \mathrm{~min}$. Esse tipo de brincadeira ocorreu também com Clarice. $\mathrm{Na}$ companhia de mais dois bebês, ela brincava de esconder-se na lateral do armário, tentando chamar a atenção da professora. Podemos afirmar que essa brincadeira se tornou recorrente entre os bebês e os adultos do Berçário I.

No dia observado, Augusto teve como principais parceiras de brincadeira Maraísa (1ano e 3 meses) e Aline (11 meses). Ocorreram duas situações de brincadeira com cada uma das meninas. Já Clarice teve como principais parceiros de brincadeira Leonardo (1 ano e 7 meses) e César (1 ano e 1 mês).

Outra tonalização das brincadeiras encontrada nos Diários foi a brincadeira entre os bebês e os adultos, como exemplificado no Quadro 19.

Quadro 19 - Tonalização - Brincadeira entre bebês e adultos

\begin{tabular}{|c|c|c|c|c|l|}
\hline Atividade & $\begin{array}{c}\text { Hora } \\
\text { início }\end{array}$ & $\begin{array}{c}\text { Hora } \\
\text { fim }\end{array}$ & Local & $\begin{array}{c}\text { Com quem } \\
\text { estava }\end{array}$ & \multicolumn{1}{c|}{ Observação } \\
\hline $\begin{array}{c}\text { Vai até } \\
\begin{array}{c}\text { Nilson e } \\
\text { depois }\end{array}\end{array}$ & $14: 21$ & $14: 25$ & $\begin{array}{c}\text { Sala } \\
\text { principal }\end{array}$ & $\begin{array}{c}\text { Nilson e } \\
\text { Patrícia }\end{array}$ & $\begin{array}{l}\text { Patrícia sentou com ela no chão, elas } \\
\text { conversavam. Patrícia tirou a meia-sapato de } \\
\text { Clarice e disse que iria colocar a meia-sapato em } \\
\text { seu pé. Ela colocou sobre o seu dedão. Clarice } \\
\text { ficou observando e gesticulou para Patrícia. } \\
\text { Clarice começou a tentar colocar a meia-sapato } \\
\text { no pé de Patrícia. }\end{array}$ \\
\hline
\end{tabular}

As brincadeiras que contaram com parceiros adultos foram expostas em 4 quadros que totalizaram 9 min em relação ao dia da semana de Augusto. No final de semana transcorreu 1 atividade com duração de 55 min.

No Diário de Clarice ocorreram 9 quadros totalizando 50 min no dia da semana. Já em relação ao registro realizado no final de semana, ocorreram 2 quadros com duração total de 1 h40min.

As brincadeiras entre adultos e os bebês estão presentes desde muito cedo na vida dos bebês. Brougère (1998) afirma que o bebê é iniciado na brincadeira pelas pessoas que cuidam dele. A criança entra progressivamente na brincadeira do adulto, de quem ela é inicialmente o brinquedo, o espectador ativo e depois o real parceiro.

A criança começa por inserir-se no jogo preexistente da mãe mais como um brinquedo do que como uma parceira, antes de desempenhar um papel mais ativo pelas manifestações de contentamento que vão incitar a mãe a continuar 
brincando. A seguir ela vai poder tornar-se um parceiro, assumindo, por sua vez, o mesmo papel da mãe, ainda que de forma desajeitada, como nas brincadeiras de esconder uma parte do corpo. A criança aprende assim a reconhecer certas características essenciais do jogo: o aspecto fictício, pois o corpo não desaparece de verdade, trata-se de um faz-de-conta; a inversão dos papéis; a repetição que mostra que a brincadeira não modifica a realidade, já que se pode sempre voltar ao início; a necessidade de um acordo entre parceiros, mesmo que a criança não consiga aceitar uma recusa do parceiro em continuar brincando. Há, portanto, estruturas preexistentes que definem a atividade lúdica em geral e cada brincadeira em particular, e a criança as apreende antes de utilizá-las em novos contextos, sozinha, em brincadeiras solitárias, ou então com outras crianças (BROUGÈRE, 1998, s/n).

As brincadeiras entre adultos e os bebês foram recorrentes. Percebemos que esse tipo de brincadeira foi mais recorrente no dia de semana de Clarice do que no de Augusto. Patrícia, uma das monitoras, foi a principal parceira de Clarice, somando 3 quadros de brincadeira em 19min. O Quadro 19 do Diário do dia da semana de Clarice ilustra essa situação. Clarice procurou Patrícia em diversos momentos do dia; neste quadro a monitora iniciou uma brincadeira com Clarice que, a partir da sua provocação, tentou dar continuidade à brincadeira. A brincadeira foi interrompida quando uma outra criança chegou; Clarice manifestou seu descontentamento ao perder a parceira de brincadeira. No caso de Augusto percebemos que a principal parceira de brincadeira foi professora do turno da tarde.

A diversidade de tonalizações nos permite perceber a diversidade de situações de brincadeira que podem ocorrer no cotidiano dos bebês. Percebemos que uma série de fatores contribuiu ou inibiu as brincadeiras. Os objetos atuaram em muitos momentos como catalisadores para as brincadeiras entre os bebês ou dos bebês sozinhos. Percebemos que algumas brincadeiras acabaram por compor o repertório de brincadeiras da turma como o esconde-esconde na lateral do armário.

O comportamento esperado para cada situação também se tornou catalisador para as brincadeiras, como no caso da brincadeira de Clarice com o copo de água. Esse objeto dentro da dinâmica do Berçário I possuía uma função específica, que era servir para beber água. Clarice, ao brincar, acaba por provocar um 'acidente' e o situa como um elemento que gera a interação dela com os adultos, que sempre tentavam fazer com que ela usasse o copo de acordo com o esperado para aquela situação.

$\mathrm{Na}$ busca de compreender, explorar, interagir, os bebês agiram ativamente na configuração dos esquemas primários. Corsaro (2011) afirma que as crianças criam e 
participam de suas culturas de pares singulares por meio da apropriação de informações do mundo adulto de forma a atender aos seus interesses próprios enquanto crianças. $\mathrm{Ou}$ seja, os bebês ao darem outros usos para os objetos, ao entrarem em um jogo com seus pares ou com os adultos, estavam buscando satisfazer seus próprios interesses, mas também dando outros significados para as situações. Observamos que nos quadros em que as crianças brincam com os adultos elas vão progressivamente significando essa relação. 


\section{CONSIDERAÇÕES FINAIS}

O objetivo central desse trabalho foi analisar o uso do tempo no cotidiano de dois bebês, tanto no contexto da creche quanto no da família, em um dia de semana e em um de final de semana. Para isso, utilizamos como instrumentos o Diário do Uso do Tempo e entrevistas. Exploramos as atividades comuns para ambos os participantes nos dois contextos sociais. Dessa forma, buscamos com esta pesquisa nos aliar ao conjunto de trabalhos desenvolvidos na área da Educação Infantil e em outros campos do conhecimento que procuram aprofundar o debate e os conhecimentos sobre os bebês.

Adotamos uma abordagem metodológica que permitiu pôr os bebês em foco. Buscamos considerar o novo paradigma da infância proposto nos estudos sociais da infância, sobretudo quando defendem a escuta à criança e o seu consequente reposicionamento como sujeito, ao invés de objetos de investigação (CHRISTENSEN; JAMES, 2008).

O Diário do Uso do Tempo mostrou-se um potente instrumento para obtermos informações sobre o cotidiano dos bebês. Ao utilizarmos esse instrumento, reforçamos a defesa de pesquisadores como Carvalho e Müller (2010, p. 68), que defendem a “[...] pluralidade de abordagens que possam enriquecer não apenas as pesquisas voltadas para infância, mas também multiplicar a presença ativa da criança no corpus de toda pesquisa". Ou ainda, como afirma Prout (2005, s/n, grifos do autor):

[...] o estudo das crianças não requer técnicas 'especiais' mas, simplesmente, uma aplicação rigorosa de exigência metodológica geral, válida para estudar os adultos ou as crianças, devendo as técnicas usadas refletir as particularidades concretas das pessoas que estão a ser estudadas.

Assim, ao utilizarmos o Diário do Uso do Tempo e consideramos as mães como coprodutoras de dados, demostramos que é viável a inclusão dos bebês nesse tipo de pesquisa.

Contamos com diferentes produtores de dados neste estudo, o que nos levou a ter que considerar diversos elementos na análise dos dados. Destacamos alguns aspectos positivos dessa diversidade. O primeiro refere-se aos responsáveis pelos bebês, que são os melhores informantes e conhecedores das rotinas de seus bebês. Garantimos que os dados gerados foram realizados por quem os conhecia profundamente. Em segundo lugar, 
as famílias sentiram-se mais confortáveis em participar da pesquisa, pois não houve a presença de um estranho acompanhando sua rotina, o que poderia gerar algum tipo de inibição em suas ações.

Em terceiro lugar, ao considerar as mães como coprodutoras dos dados, acessamos a forma como elas compreendem as atividades dos bebês na organização familiar. Ao escreverem os registros, as mães produziram um recorte da realidade, o qual nos permitiu saber implicitamente acerca das suas concepções sobre as ações dos bebês. Ou seja, as coprodutoras de dados desta pesquisa disponibilizaram não só informações sobre o uso do tempo, assim como inúmeras concepções a ele atreladas, tais como: qual atividade descrever ou omitir, o que é considerado uma atividade ou não do bebê. Também encontramos certas fragilidades nessa abordagem, como o enviesamento dos dados pela alta carga de subjetividade, visto que se trata da relação entre mães e filhos. Contudo, este ponto foi amenizado com as entrevistas e análises, que sempre buscaram dar mais objetividade à leitura dos dados.

$\mathrm{Na}$ análise percebemos que os bebês participam de uma série de situações sociais a partir das interações estabelecidas. A dinâmica interacional, as necessidades e desejos dos bebês, a estruturação do tempo e a ordem social estabelecida definiram o maior ou menor enquadramento dos bebês nas situações vivenciadas. Bebês são capazes de identificar os comportamentos esperados deles nas diferentes situações sociais. Dentro das atividades vivenciadas pelos bebês na creche e na família, destacamos aquelas que foram comuns nesses dois contextos sociais. Problematizamos assim duas categorias pedagógicas: os cuidados e as brincadeiras.

Ao compararmos a quantidade de tempo para ambos os bebês, pudemos notar que as atividades dos bebês popularmente definidas como necessidades biológicas que seguem um "relógio biológico" - sono, alimentação e higiene - são também reguladas socialmente. Como Denys Cuche (1999) afirma, nada é natural no homem, mas ele é informado pela cultura. Nas palavras do autor:

A natureza, no homem, é inteiramente interpretada pela cultura. As diferenças que poderiam parecer mais ligadas a propriedades biológicas [...] resulta fundamentalmente da cultura e por isso varia de uma sociedade para outra.

Nada é puramente natural no homem. Mesmo as funções humanas que correspondem a necessidades fisiológicas, como a fome, o sono, o desejo sexual, etc são informados pela cultura, as sociedades não dão exatamente as 
mesmas respostas a estas necessidades. A fortiori, nos domínios em que não há constrangimento biológico, os comportamentos são orientados pela cultura. Por isso, a ordem; "Seja natural", frequentemente feita às crianças, em particular nos meios burgueses, significa, na realidade: "Aja de acordo com o modelo da cultura que lhe foi transmitido" (CUCHE, 1999, p. 10-11, grifos do autor).

Destacamos que cada uma das situações vivenciadas pelos bebês foi marcada por um ethos que permitiu a eles se localizarem no tempo e no espaço, compreendendo assim qual era o comportamento deles esperado. Percebemos que nas situações caracterizadas como cuidados e brincadeiras, os bebês se apropriaram das informações e negociaram suas necessidades com os envolvidos. A exemplo do que aconteceu quando Clarice se recusou a comer a comida pastosa, uma vez que já comia alimentos sólidos, ou no caso de Augusto que estava doente e teve seu tempo muito mais estruturado em função da sua condição do que no tempo estruturado pela rotina da creche.

Em casa a organização do tempo seguiu tanto as necessidades do bebê quanto a organização social da família. Isadora, mãe de Augusto, nos relatou que muitas vezes levava o filho quando necessitava usar o banheiro. Tratava-se de momentos em que ela aproveitava para tomar banho e deixar o bebê brincando. Assim, esses momentos se configuravam em situações em que a mãe tinha segurança em ter o filho sob a sua supervisão, como também por um momento de interação da mãe com o bebê, além de cumprir como uma necessidade pessoal dela.

Observamos que as brincadeiras ocorreram em diversos momentos; algumas surgiram do imprevisto, outros da estruturação do tempo pelos adultos. Na creche, as brincadeiras com brinquedos fizeram parte da rotina da turma, enquanto a brincadeira entre pares e com os adultos ou sozinhos foram desenrolando-se na sequência dos eventos. Elas dependeram da disponibilidade dos adultos, da condição física das crianças, do olhar sensível do adulto para promover e mediar brincadeiras entre os bebês.

No contexto da família as brincadeiras ocorreram em momentos planejados ou não. Na família de Augusto, apesar de a mãe afirmar na entrevista que ele brincava pouco, os registros mostram que as brincadeiras ocorriam em diversos momentos. Elas estavam mais integradas às atividades relacionadas aos cuidados pessoais. Ela relatou na entrevista que organizava o espaço para que Augusto brincasse durante o tempo em que tomava banho com ela. 
Observamos também que o tempo gasto nas brincadeiras no contexto familiar era negociado entre os adultos e os bebês. A mãe de Clarice relatou que normalmente levava a filha para brincar no parque, gastando em média cerca de 30 minutos. Contudo, no dia relatado, percebemos que elas gastaram 1 hora nessa atividade.

As situações que ocorrem na família possuíam um enredo pré-definido, contudo não significou que essa organização fosse rígida. Os pais tentaram estruturar os tempos para os bebês, mas a rotina da família foi sendo construída por todos os seus membros. Os pais de Augusto tiveram a agenda no final de semana preenchida por atividades externas ao espaço da casa. Assim, o bebê teve seu tempo organizado segundo as necessidades dos pais. Isso não significou que apenas o tempo dos pais foi responsável por organizar a agenda do final de semana, pois também usufruíram de um tempo organizado para atender aos interesses do bebê, como levá-lo para brincar em uma praça. Bondioli (2004), igualmente aborda essa questão em seu estudo. A autora afirma que a rotina da família possui momentos costumeiros e rotineiros onde uma sequência de eventos se sucede: banho seguido de jantar, por exemplo, mas estes são reinterpretados em função do humor e das necessidades da criança.

As atividades dos bebês mostraram-se parte importante da organização do tempo familiar e, em alguns casos, com mais ou menos centralidade na família. As descrições feitas no diário de Clarice estão mais ligadas às atividades da família em geral; o tempo de alimentação descrito não diz respeito ao tempo gasto somente pela filha durante as refeições, e sim ao tempo do conjunto da família nessa atividade. Já o diário do uso do tempo de Augusto contempla mais a duração das atividades específicas da criança, dando uma centralidade ao bebê nesse contexto familiar.

$\mathrm{Na}$ creche houve uma estruturação mais rígida do tempo e do espaço. O modelo adotado para a organização de um considerável número de crianças por turma organizadas por série, ou seja, as crianças de cada turma possuem mais ou menos a mesma idade - impôs uma estruturação mais rígida do tempo cotidiano. A rotina da instituição previa as mesmas atividades para todos os bebês ao mesmo tempo.

Observamos que o tempo que cada criança gastou nas atividades de alimentação ou higiene representou uma pequena parte do seu dia. Contudo, consideramos esse tempo na organização da turma expressivo, pois era necessário alimentar ou dar banho em todos 
os bebês ao mesmo tempo. Por outro lado, esses podem ter sido os momentos de encontros dos bebês com menor interferência dos adultos.

Por fim, consideramos que a inclusão dos bebês nesses tipos de estudo sobre o Uso do Tempo poderia facilitar os estudos comparativos acerca do cotidiano desses sujeitos em diferentes contextos socioculturais, contribuindo para uma melhor compreensão da infância. É necessário aliar o Diário do Uso do Tempo a outros instrumentos para poder captar as omissões e poder compreender quais são as referências empregadas para a produção de recortes da realidade a serem registrados nos Diários. 


\section{REFERÊNCIAS}

ADES, C. A experiência psicológica da duração. Ciência e Cultura, São Paulo, v. 54, n. 2, p. 26-29, 2002.

AGUIAR, N. Metodologias para o levantamento do uso do tempo na vida cotidiana no Brasil. Revista Econômica, Rio de Janeiro, v. 12, n. 1, p. 64-82, 2010.

ANJOS, A. M. et al. Interações de bebês em creche. Estudos de Psicologia, Natal, v. 9, n. 3, p. 513-522, 2004.

ARIÈS, P. História social da criança e da família. Tradução Dora Flaksman. 2. ed. Rio de Janeiro: LTC, 1981.

BARBOSA, M. C. S. Por amor e por força: rotinas na Educação Infantil. Porto Alegre: Artmed, 2006.

BARBOSA, M. C. Especificidades da ação pedagógica com os bebês. In: I SEMINÁRIO NACIONAL: CURRÍCULO EM MOVIMENTO - PERSPECTIVAS ATUAIS, 2010, Belo Horizonte. Anais... Belo Horizonte, 2010. p. 1-17.

BARBOSA, M. C. S.; FOCHI, P. S. O desafio da pesquisa com bebês e crianças bem pequena. In: IX REUNIÃO DA ANPED SUL, 2012, Caxias do Sul. Anais... Caxias do Sul, 2012. p.1-13.

BARBOSA, M. C. S. A ética na pesquisa etnográfica com crianças: primeiras problematizações. Práxis Educativa, Ponta Grossa, v. 9, n. 1, p. 235-245, 2014.

BATISTA, R. A rotina no dia-a-dia da creche: entre o proposto e o vivido. Florianópolis, SC. Dissertação de Mestrado. Universidade Federal de Santa Catarina, 1998.

BRASIL. Constituição da República Federativa do Brasil, 1988.

BRASIL. Estatuto da Criança e do Adolescente: Lei federal nº 8069, de 13 de julho de 1990.

BRASIL. Lei de Diretrizes e Bases da Educação Nacional - LDB, n. 9394/1996.

BRASIL. Conselho Nacional de Educação/Câmara de Ensino Básico. Diretrizes Curriculares Nacionais para a Educação Infantil. Brasília, 2009.

BRASIL. Plano Nacional de Educação. Brasília. 2014.

BRASIL. Instituto Nacional de Estudos e Pesquisas Educacionais Anísio Teixeira. Sinopses Estatísticas da Educação Básica 2013. Brasília, 2014.

BRASIL. Instituto Nacional de Estudos e Pesquisas Educacionais Anísio Teixeira. Censo Escolar da Educação Básica 2013: resumo técnico. Brasília, 2014. 
BECCHI, E.; BORANDO, A. O cotidiano doméstico de crianças pequenas: distribuição do tempo, pessoas, comunicações, ações. In: BONDIOLI, A. (org.). O tempo no cotidiano infantil: perspectivas de pesquisa e estudo de casos, São Paulo: Cortez, 2004.

BEN-ARIEH, A.; OFIR, A. Opinion, dialogue, review. Time for (more) Time-Use studies: studying the daily activities of children. Childhood, v. 9, n. 2, p. 225-248, 2002.

BILAC, E. D. Família: algumas inquietações. In: BILAC, E. D. A família contemporânea em debate. São Paulo: EDUC/Cortez, 2002. p. 122.

BONDIOLI, A. (org.). O tempo no cotidiano infantil: perspectivas de pesquisa e estudo de casos. São Paulo: Cortez, 2004.

BONDIOLI, A. A observação do contexto educativo: uma perspectiva de pesquisa sobre os tempos do cotidiano. In: ___ O tempo no cotidiano infantil: perspectivas de pesquisa e estudo de casos. São Paulo: Cortez, 2004.

BOURDIEU, P. Goffman, o descobridor do infinitamente pequeno. In: GASTALDO, É. (org). Erving Goffman: desbravador do cotidiano. Porto Alegre: Tomo Editorial, 2004.

BROUGÈRE, G. A criança e a cultura lúdica. Revista da Faculdade de Educação, São Paulo, v. 24, n. 2, 1998.

BROUGÈRE, G. Brinquedos e companhia. Tradução: Maria Alice A. Sampaio Doria. São Paulo: Cortez, 2004.

BRUSCHINI, C. Uma abordagem sociológica de família. Revista Brasileira de Estudos de População, Rio de Janeiro, v. 6, n. 1, p. 1-23, 1989.

CAMARA, H. G. Do olhar que convoca ao sorriso que responde: possibilidades interativas entre bebês. Porto Alegre: UFRGS, 2006. 107p. Dissertação (Mestrado em Educação) - Programa de Pós-Graduação em Educação, Universidade Federal do Rio Grande do Sul, Porto Alegre, 2006.

CAMPOS, M. A formação de professores para crianças de 0 a 10 anos: modelos em debate. Educação e Sociedade, Campinas, n. 68, p. 126-142, 1999.

CAMPOS, M. M.; FÜLLGRAF, J.; WIGGERS, V. A qualidade da Educação Infantil brasileira: alguns resultados de pesquisa. Cadernos de Pesquisa, v. 36, n. 127, p. 87128, 2006.

CARDOSO, A. C. M. Tempos de trabalho, tempos de não trabalho: disputas em torno da jornada do trabalhador. São Paulo: Annablume, 2009.

CARVALHO, A. M. A. et al. Dinâmica interacional de crianças em grupo: um ensaio de categorização. Psicologia em Estudo, Maringá, v. 7, n. 2, p. 91-99, 2002.

CARVALHO, A. M. A.; PEDROSA, M. I. Cultura no grupo de brinquedo. Estudos de Psicologia, Natal, v. 7, n. 1, p. 181-188, 2002. 
CARVALHO, M. J. S.; MACHADO, J. B. Análise dos usos do tempo entre crianças acerca das relações de gênero e de classe social. Currículo sem Fronteiras, v. 6, n. 1, p. 70-81, 2006.

CARVALHO, A. F.; MÜLLER, F. Ética nas pesquisas com crianças: uma problematização necessária. In: MÜLLER, F. (Org). Infância em perspectiva: políticas, pesquisa e instituições. São Paulo: Cortez, 2010.

CARVALHO, E. R. Norbert Elias frente aos desafios de superação da aporia entre tempo físico e tempo social. In: RANGEL, M. M.; PEREIRA, M. H. F.; ARAUJO, V. L. (Orgs). Caderno de resumos \& Anais do $6^{\circ}$ Seminário Brasileiro de História da Historiografia - O giro-linguístico e a historiografia: balanço e perspectivas. Ouro Preto: EdUFOP, 2012.

CASTELLS, M. O limiar do eterno: tempo intemporal. In: A sociedade em rede. A era da informação: economia, sociedade e cultura; v.1. 6. ed. São Paulo: Paz e Terra, 1999.

CERISARA, A. B. Professoras de Educação Infantil: entre o feminino e o profissional. São Paulo: Cortez, 2002.

CHAMBOREDON, J. C.; PRÉVOT, J. O "Ofício de criança": definição social da primeira infância e funções diferenciadas da escola maternal. Cadernos de Pesquisa, São Paulo: Fundação Carlos Chagas, n. 59, p. 32 - 56, 1986.

CHRISTENSEN, P.; JAMES, A. Childhood Diversity and Commonality: some methodological insights. In: London: Routledge, p. 156-172, 2008. Research with children: perspectives and practices.

CORSARO, W. A. Sociologia da Infância. Porto Alegre: Artmed, 2011.

COUTINHO, A. S. As crianças no interior da creche: a educação e o cuidado nos momentos de sono, higiene e alimentação. Florianópolis: UFSC, 2002. 164p. Dissertação (Mestrado em Educação) - Programa de Pós-Graduação em Educação, Universidade Federal de Santa Catarina, Florianópolis, 2002.

COUTINHO, A. S. A ação social dos bebês: um estudo etnográfico no contexto da creche. Portugal: Universidade do Minho, 2010. Tese (Doutoramento em Estudos da Criança Especialidade em Sociologia da Infância) - Instituto de Educação, Universidade do Minho, Portugal, 2010.

COUTINHO, A. S. Os bebês e a brincadeira: questões para pensar a docência. $D a$ investigação às práticas, Lisboa, v. 4, n. 1, p. 31-47, 2013.

CRAIG, L. Time-Use Studies. In: MELTON, G. B.; BEN-ARIEH, A.; CASHMORE, J.; GOODMAN, G. S.; WORLEY, N. K.(orgs.). The Sage Handbook of Child Research. e-book. Sage, Londres, 2014.

CRESWELL, J. W. Projeto de pesquisa: métodos qualitativo, quantitativo e misto. Tradução Magda França Lopes. 3. ed. Porto Alegre: Artmed, 2010. 
CUCHE, D. A noção de cultura nas ciências sociais. Bauru: EDUSC, 1999.

CUNNINGHAM, H. The Children of the Poor: Representations of Childhood since the Seventeenth Century, Oxford: Blackwell, 1991.

CUNNINGHAM, H.; VIAZZO, P.P. (Org.). Child Labour in Historical Perspective 1880- 1985: case studies from Europe, Japan and Colombia, Florence, Italy:

UNICEF/ICDC, 1996.

ELIAS, N. Sobre o tempo. Tradução Vera Ribeiro. Rio de Janeiro: Jorge Zahar, 1998.

EUROSTAT, E. C. Guidelines on harmonised European Time Use surveys.

Luxemburgo: Luxemburgo, 2004.

FAEDI, G. Introdução. In: BONDIOLI, A. (Org.). O tempo no cotidiano infantil: perspectivas de pesquisa e estudo de casos. São Paulo: Cortez, 2004.

FARIA, A. L. G. Pequena infância, educação e gênero: subsídios para um estado da arte. Cadernos Pagu, Campinas, v. 26, p. 279-287, 2006.

FERNANDES, F. As “Trocinhas” do Bom Retiro. Pro-Posições, Campinas, v. 15, n. 1 (43), p. 229-250, 2004.

FERRARI, M. O dia-a-dia educativo na escola elementar. In: BONDIOLI, A. (Org.). $O$ tempo no cotidiano infantil: perspectivas de pesquisa e estudo de casos. São Paulo: Cortez, 2004.

FERREIRA, M. “- Ela é nossa prisioneira!” - questões teóricas, epistemológicas e éticometodológicas a propósito dos processos de obtenção da permissão das crianças pequenas numa pesquisa etnográfica. Revista Reflexão e Ação, Santa Cruz do Sul, v. 18, n. 2, p. 151-182, 2010.

FONTOURA, N. et al. Pesquisas de uso do tempo no Brasil: contribuições para a formulação de políticas de conciliação entre trabalho, família e vida pessoal. Revista Econômica, Rio de Janeiro, v. 12, n. 1, p. 11-46, 2010.

FRANCHI e VASCONCELOS, C. R. et al. A incompletude como virtude: interação de bebês na creche. Psicologia: Reflexão e Crítica, Rio Grande do Sul, v. 16, n. 2, p. 293301, 2003.

GALDABINO, E. O dia-a-dia educativo na creche. In: BONDIOLI, A. (Org.). O tempo no cotidiano infantil: perspectivas de pesquisa e estudo de casos. São Paulo: Cortez, 2004.

GARIBOLDI, A. Os tempos cotidianos na pré-escola: as formas da sociabilidade. In: BONDIOLI, A. (Org.). O tempo no cotidiano infantil: perspectivas de pesquisa e estudo de casos. São Paulo: Cortez, 2004.

GEERTZ, C. Saber local: novos ensaios em antropologia interpretativa. 6. ed. Petrópolis: Vozes, 2003. 
GIL, A. C. Métodos e técnicas de pesquisa social. 6. ed. São Paulo: Atlas, 2008.

GIL, A. H. C. F.; GIL FILHO, S. F. Geografia do cotidiano: uma leitura da metodologia sócio-interacionista de Erving Goffman. Ateliê Geográfico, Goiânia, v. 2, n. 2, p.102$118,2008$.

GOBBATO, C. “Os bebês estão por todos os espaços!”: um estudo sobre a educação de bebês nos diferentes contextos de vida coletiva da escola infantil. Porto Alegre: UFRGS, 2011. 223p. Dissertação (Mestrado em Educação) - Programa de PósGraduação em Educação, Universidade Federal do Rio Grande do Sul, Porto Alegre, 2011.

GOFFMAN, E. A Reply to Denzin and Keller Frame Analysis : an essay on the organization of experience. Contemporary Sociology, v. 10, n. 1, p. 60-68, 1981.

GOFFMAN, E. Comportamentos em lugares públicos: notas sobre a organização social dos ajuntamentos. Petrópolis: Vozes, 2010.

GOFFMAN, E. Os quadros da experiência social: uma perspectiva de análise.

Petrópolis: Vozes, 2012a.

GOFFMAN, E. Ritual de interação: ensaios sobre o comportamento face a face. 2. ed. Petrópolis, RJ: Vozes, 2012b.

GOFFMAN, E. A representação do eu na vida cotidiana. 19. ed. Petrópolis: Vozes, 2013.

GOLDANI, A. M. As famílias no Brasil contemporâneo e o mito da desestruturação. Campinas. Cadernos Pagu, v. 1, p. 67-110, 1993.

GOLDENBERG, M. A arte de pesquisar: como fazer pesquisa qualitativa em Ciências Sociais. 8. ed. Rio de Janeiro: Record, 2004.

GOTTLIEB, A. Tudo começa na outra vida: a cultura dos recém-nascidos no Oeste da África. Tradução Mara Sobreira. São Paulo: Fap-Unifesp, 2012.

GOVERNO DO DISTRITO FEDERAL. Censo Escolar da Secretaria de Estado de Educação do Distrito Federal 2013. Brasília, 2013.

GUARINELLO, N. L. História científica, história contemporânea e história cotidiana. Revista Brasileira de História, v. 24, n. 48, p. 13-38, 2004.

GUIMARÃES, D. Relações entre adultos e bebês na creche: o cuidado como ética. São Paulo: Cortez, 2011.

HANGAI, L. A. A. Framing Analisys de Goffman e sua aplicação nos estudos em Comunicação. Revista Açãomidiática - Estudos em Comunicação, Sociedade e Cultura. Universidade Federal do Paraná Programa de Pós Graduação em Comunicação. v. 2. n. $1,2012$. 
HUIZINGA, J. Homo Luden: o jogo como elemento da cultura. Tradução João Paulo Monteiro. 4. ed. São Paulo: Editora Perspectiva S.A., 2000.

JAMES, A; JAMES, A. Key Concepts in Childhood Studies. e-book. London: Sage, 2008 .

JAMES, A.; PROUT, A. A New Paradigm for the Sociology. In: Constructing and reconstructing childhood. London: Falmer Press, 1999.

KENNEDY, D.; KOHAN, W. Aión, Kairós and Chrónos: Fragments of an Endless Conversation on Childhood, Philosophy and Education. Childhood \& Philosophy, v. 4, n.8, 2008.

KOHAN, W. O. A infância da educação: o conceito devir-criança. In: Lugares da infância: filosofia. Rio de Janeiro: DP\&A, 2004.

KRAMER, S. Direitos da criança e projeto político-pedagógico de Educação Infantil In: BASÍLIO, Luís C.; KRAMER, S. Infância, Educação e Direitos Humanos. São Paulo: Cortez, 2003.

KUHLMANN JR., M. Infância e educação infantil: uma abordagem histórica. 5. ed. Porto Alegre: Mediação, 2010.

LARSON, R. W.; VERMA, S. How children and adolescents spend time across the world: work, play, and developmental opportunities. Psychological bulletin, v. 125, n. 6, p. 701-36, 1999.

LEITE, R. P. A inversão do cotidiano: práticas sociais e rupturas na vida urbana contemporânea. Dados - Revista de Ciências Sociais, v. 53, n. 3, p. 737-756, 2010.

LUKER, K. Salsa dancing into the social sciences: research in an age of info-glut. ebook. Cambridge: Harvard University Press, 2008.

MANNING, P. Erving Goffman and Modern Sociology. California: Stanford University Press, 1992.

MARQUES, N.; MENNA-BARRETO, L. Grupo de estudos sobre o tempo. Estudos Avançados. São Paulo, v. 4, n. 8, 1990.

MENDONÇA, R. F.; SIMÕES, P. G. Enquadramento: diferentes operacionalizações analíticas de um conceito. Revista Brasileira de Ciências Sociais. São Paulo, v. 27, p. 187-201, 2012.

MINKOFF, Y.; RILEY, J. Perspectives of Time-Use: exploring the use of drawings, interviews and rating-scales with children aged 6-7 years. Journal of Occupational Science, v. 18, n. 4, p. 306-321, 2011.

MONTENEGRO, T. Educação Infantil: a dimensão moral da função de cuidar. Revista Psicologia da Educação. São Paulo, n. 20, p.77-101, 2005. 
MORROW, V. The ethics of social research with children and young people - an overview. London University of London/Institute of Education, [s.d.].

MOTA, M. E. D. Psicologia do Desenvolvimento: uma perspectiva histórica. Temas em psicologia. Ribeirão Preto, v. 13, n. 2, p. 105-111, 2005.

MULVIHILL, C.; RIVERS, K; AGGELTON, P. Physical Activity 'At Our Time': qualitative research among young people aged 5 to 15 and parents. London: Health Education Authority, 2000.

NIEUWENHUYS, O. Children's Lifeworlds. Gender, Welfare and Labour in the Developing World. Londres, New York: Routledge, 1994.

NIGITO, G. Tempos institucionais, tempos de crescimento: a gestão do cotidiano dos pequenos, dos médios e dos grandes na creche. In: BONDIOLI, A. (Org.). O tempo no cotidiano infantil: perspectivas de pesquisa e estudo de casos. São Paulo: Cortez, 2004.

NUNES, B. F. Sociedade e infância no Brasil. Brasília: Editora Universidade de Brasília, 2003.

NUNES, J. A. Erving Goffman, a análise de quadros e a Sociologia da Vida Quotidiana. Revista Crítica de Ciências Sociais. Coimbra, n. 37, 1993.

OBSERVATÓRIO do PNE. Indicadores da Educação Infantil. Disponível em: <http://www.observatoriodopne.org.br/metas-pne/1-educacao-infantil/indicadores>. Acesso em 07 de abril de 2015.

OLIVEIRA, I. B. Estudos do cotidiano, pesquisa em educação e vida cotidiana: o desafio da coerência. ETD - Educação Temática Digital. Campinas, v.9, n. esp., p.162$184,2008$.

PATTO, M. H. S. O conceito de cotidianidade em Agnes Heller e a pesquisa em educação. Perspectivas, v. 16, p. 119-141, 1993.

PINHEIRO, L; GALIZA, M; FOUNTURA, N. Novos arranjos familiares, velhas convenções sociais de gênero: a licença-parental como política pública para lidar com essas tensões. Revista Estudos Feministas. Florianópolis, v. 17, n. 3, 2009.

PECORA, N; MURRAY, J.P.; WARTELLA, E. (Orgs.). Children and Television: Fifty Years of Research. London: Routledge, 2006.

PROUT, A. Reconsiderando a nova sociologia da infância. Cadernos de Pesquisa. São Paulo, v. 40, n. 141, 2010.

PROUT, A. Prefácio. In: CHRISTENSEN, P.; JAMES, A. Investigação com crianças: perspectivas e práticas. Porto: Escola Superior de Educação de Paula Frassinetti, 2005.

PUNCH, S. Children's Strategies for Creating Playspaces: negotiating independence in rural Bolivia. In: HOLLOWAY, S. L.; VALENTINE, G. (Orgs.) Geographies: Playing, Living, Learning. London, New York: Routledge, 2000. 
REYNOLDS, P. Dance Civet Cat: Child Labour in the Zambezi Valley. Athens: University of Ohio Press, 1991.

ROSSETTI-FERREIRA, M. C.; AMORIM, K. S.; SILVA, A. P. S. Uma perspectiva teórico-metodológica para análise do desenvolvimento humano e do processo de investigação. Psicologia: Reflexão e Crítica, Rio Grande do Sul, v.13(2), 281-293, 2000 .

ROSSETTI-FERREIRA, M. C.; AMORIM, K. S.; OLIVEIRA, Z. M. R. Olhando a crianças e seus outros: uma trajetória de pesquisa em educação infantil. Psicologia USP, São Paulo, v. 20, n. 3, p. 437-464, 2009.

SCHMITT, R. V. "Mas eu não falo a língua deles!": as relações sociais de bebês num contexto de educação infantil. Florianópolis: UFSC, 2008. 217 p. Dissertação (Mestrado em Educação) - Programa de Pós-Graduação em Educação, Universidade Federal de Santa Catarina, Florianópolis, 2008.

SILVA, I. O. et. al. Grupo de pesquisa sobre infância, criança e educação infantil no Brasil: primeiras aproximações. Revista Brasileira de Educação, Rio de Janeiro, v. 15, n. 43, p. 84-97, 2010.

SZYMANSKY, H. Teorias e "teorias" de famílias. In: CARVALHO, M. C. B. (Org.) A família contemporânea em debate. São Paulo: EDUC: Cortez, 2002.

TEIXEIRA, V.; CRUZ, O. O uso do tempo das crianças - um estudo comparativo entre 1999 e 2006. In: I CONGRESSO INTERNACIONAL EM ESTUDOS DA CRIANÇA - INFÂNCIAS POSSÍVEIS, MUNDOS REAIS. Anais... Braga, $2006 a$.

TEIXEIRA, V.; CRUZ, O. O "diário de uso do tempo" - uma metodologia para estudar o uso do tempo das crianças. In: XI CONFERÊNCIA INTERNACIONAL AVALIAÇÃO PSICOLÓGICA: FORMAS E CONTEXTOS. Anais... Braga, 2006b.

TONUCCI, F. Quando as crianças dizem: agora chega! Porto Alegre: Artmed, 2005.

VOGLER, P.; MORROW, V.; WOODHEAD, M. Conceptualising and measuring children's time use: a technical review for Young Lives. Young Lives Technical Note, 2009.

WAGNER, G. Children of the Empire. London: Weidenfeld and Nicolson, 1982.

WAJSKOP, G. O brincar na educação infantil. Caderno de Pesquisa. São Paulo, v. 92, p. 62-69, 1995.

WHITROW, G. J. O tempo na história: concepções de tempo da pré-história aos nossos dias. Tradução Maria Luiza X. de A. Borges. Rio de Janeiro: Jorge Zahar, 1993.

YEUNG, W. J.; SANDBERG, J. F.; DAVIS-KEAN, P. E.; HOFFERTH, S. L. 'Children's Time with Fathers in Intact Families'. Journal of Marriage and Family, v. 63, p. 136-154, 2001. 
ZEIHER, H. O tempo no cotidiano das crianças. In: BONDIOLI, A. (Org.). O tempo no cotidiano infantil: perspectivas de pesquisa e estudo de casos. São Paulo: Cortez, 2004.

ZEIHER, H. Tempo da profissão e tempo da família: suas modificações sociais. In:

SOUZA, G. (Org.). A criança em perspectiva: o olhar do mundo sobre o tempo Infância. São Paulo: Cortez, 2007.

ZELIZER, V. A. Pricing the Priceless Child: The Changing Social Value of Children, New York: Basic Books, 1985. 
ANEXO

Anexo A - Parecer de AProvação do Comitê de Ética em PesQuisa

\author{
INSTITUTO DE CIENCIAS \\ HUMANAS / UNIVERSIDADE \\ DE BRASILIA / CAMPUS
}

\title{
PARECER CONSUBSTANCIADO DO CEP
}

\section{DADOS DO PROJETO DE PESQUISA}

Titulo da Pesquisa: O uso do tempo pelosipara os bebès

Pesquisador: Lucélia de Almeida Silva

Área Tematica:

Versào: 1

CAAE: 19920913.0 .0000 .5540

Instituiçăo Proponente: Instituto đe Ciências Humanas

Patrocinador Principal: Financiamento Próprio

DADOS DO PARECER

Número do Parecer: 393.624

Data da Relatoria: 06/09/2013

Apresentaçäo do Projeto:

Trata-se de uma pesquisa de mestrado que tem o objetivo de identificar como se dá o uso do tempo por dois bebès, um menino e uma menina que frequentam uma creche pública de Brasilia, considerando as determinaçōes do tempo para eles pelos adultos.

\section{Objetivo da Pesquisa:}

A pesquisa pretende compreender o uso do tempo pelos bebês tanto no contexto familiar como no contexto da creche. Para a pesquisadora, o uso do tempo por bebès năo é realizado de forme passiva, propondo a identificação $e$ anảise deșsa dinâmica que envolve a relação entre bebê e cuidadores no uso dọ tempo

\section{Avaliaçào dos Riscos e Beneficios:}

A pesquisa nầo prevê riscos para os participantes.

Comentários e Consideraçóes sobre a Pesquisa:

A pesquisa prevê a combinação de duas técnicas de pesquisa: o preenchimento de um diârio de tempo pelos responsáveis pelos bebés e posterior entrevista com estes responsáveis para esclarecer alguns pontos dos diários. A pesquisadora apresenta os instrumentos $\theta$ detalha adequadamente as etapas de coleta dos dados.

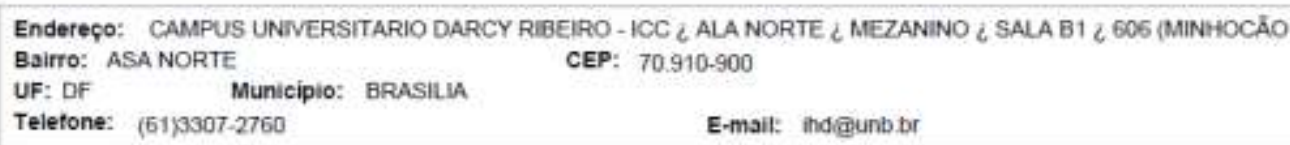




\section{INSTITUTO DE CIENCIAS HUMANAS / UNIVERSIDADE DE BRASÍLIA / CAMPUS}

Continuą̧̃o do Parecer 393,624

\section{Consideraçŏes sobre os Termos de apresentaçăo obrigatória:}

A pesquisadora apresenta TCLE em concordância com as exigencias da Resolução $196 / 96$ e resoluçöes complementares. A linguagem do termo está acessivel e as etapas da pesquisa estăo adequadamente descritas

A pesquisadora apresenta, ainda, Carta de Aceite Institucional devidamente assinada $\theta$ os demais documentos exigidos pela normatizaçăo vigente e por este Comitê.

Recomendaçōes:

Conclusŏes ou Pendéncias e Lista de Inadequaçöes:

Sugiro que o projeto seja aprovado pelo colegiado deste Comité.

Situaçäo do Parecer:

Aprovado

Necessita Apreciaçăo da CONEP:

Nà̀

Consideraçöes Finais a criterio do CEP:

BRASILIA, 12 de Setembro de 2013

Assinador por:

Debora Diniz Rodrigues

(Coordenador)

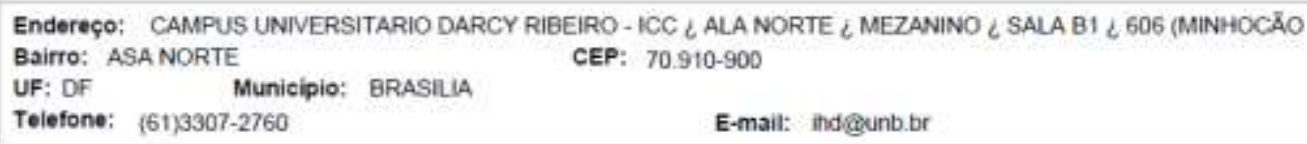

